Journal of the Scientific Agricultural Society of Finland

Vol. 45: 17-119 1973

Maataloustieteellinen Aikakauskirja

\title{
BOARS FOR BREEDING: A STUDY OF METHODS OF EVALUATION USED AT TESTING STATIONS
}

Selostus: Karjujen koeasematestauksen tuloksellisuudesta

ELSI ETTALA

Department of Animal Breeding, University of Helsinki ${ }^{\mathbf{1}}$ )

ACADEMic dissertation

TO BE PRESENTED, WITH THE PERMISSION OF

the Faculty of Agriculture and Forestry

OF THE UNIVERSITY OF HELSINKI, FOR PUBLIC

criticism in the Small Festival Hall on

MAY 2ND, 1973, AT 12 o'ClOCK.

1) Present address: Agricultural Research Centre,

Department of Animal Husbandry, Tikkurila, Finland 


\section{Preface}

The first part of the study was carried out at the Pig Husbandry Testing Station of North Finland, Haapajärvi, in 1967-1969, and the second part at the Agricultural Research Centre, Tikkurila, in 1969-1972.

I wish to express my gratitude to Professor Mıкко VARo, Principal of the Department of Animal Breeding, University of Helsinki, who gave me this research topic, and much valuable advice and inspiration during the course of the work.

I wish to thank Professor Martti Lampila, Principal of the Department of Animal Husbandry, Professor Kalle Majuala, Principal of the Department of Animal Breeding, both of the Agricultural Research Centre, Tikkurila and Mr. Johannes Partanen, M.Sc., Principal of the Pig Husbandry Testing Station, Hyvinkää, for providing the facilities for the second part of the study.

I wish to thank Mr. Erkiki Nenonen, M. A., and Mr. Veijo Vilva, B. A., for preparing the statistical programmes, and Mrs. LiIsA Mattila, M. A., for assistance in their use. I also wish to thank Mr. Unto Uusisalmi, B.Sc., for many valuable suggestions concerning the analysis of the data.

I thank Mr. David Homer, B.Sc., and Dr. UlF Lindström for linguistic corrections to the manuscript in its translated form.

I thank the then-functioning Board of the Pig Husbandry Testing Station of North Finland for support received during the first part of the study. I wish to offer particularly warm thanks to one Board member, Dr. KeRTTu SAALASTI, for continued interest and encouragement at all the stages of the work.

I thank the executives and staff of the Artificial Insemination Society of North Finland and Salpausselkä for all assistance, without which this study would have been impossible. I wish, in particular, to thank Mrs. Irma HolopaINEN, animal husbandry technician for her help in performing the tests on the progeny. I also thank the staff of the Pig Husbandry Testing Stations of North Finland and Hyvinkää for their conscientious work. I also wish to thank all those persons who, in slaughterhouses, on farms etc., assisted me in the study.

I wish to thank the Department of Pig Husbandry of the Finnish Animal Breeding Association and the Artificial Insemination Societies which provided economic support in purchasing the test boars.

I wish to thank the August Johannes and Aino Tiura Agricultural Research Foundation and the Fund for the Advanced Training of Agronomists for scholarships.

Tikkurila, January, 1973 



\section{CONTENTS}

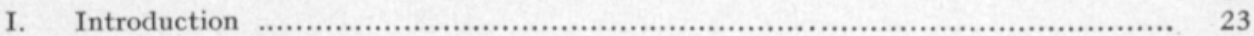

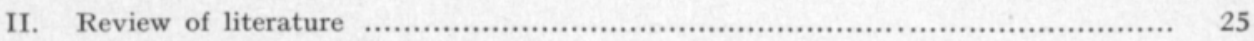

A. Ultrasonic measurement of the fat thickness and the meatiness of live pigs ...... 25

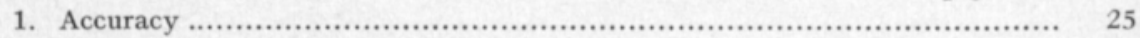

2. Fat thickness and cross-sectional area of longissimus muscle as indicators of meatiness and fat content of carcass ....................................... 28

B. Rate of growth and feed efficiency as criteria in the phenotype testing of boars ... 30

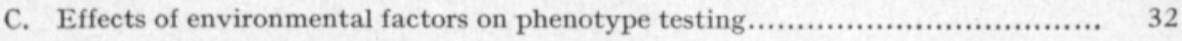

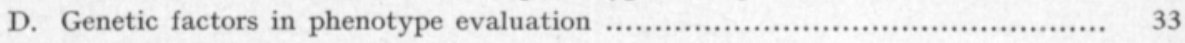

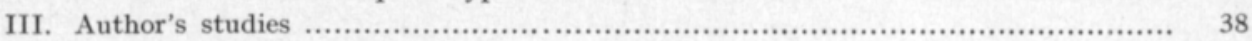

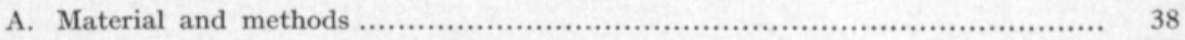

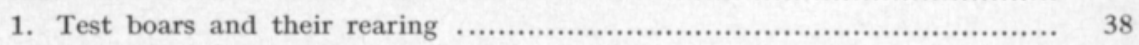

2. Evaluation, selection and use in breeding of test boars ......................... 39

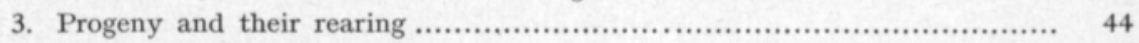

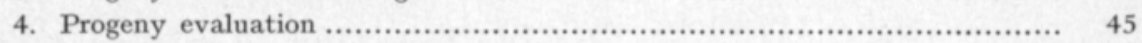

5. Statistical methods ................................................................... 47

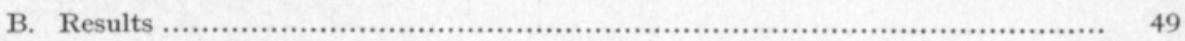

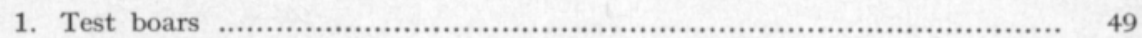

a. Phenotype evaluation: results and factors affecting them ................... 49

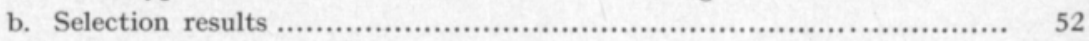

c. Interrelationships between characteristics ................................ 53

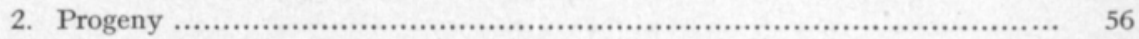

a. Phenotype evaluation: results and factors affecting them ................. 56

b. Carcass evaluation and lean cuts results of progeny ........................... 63

3. Results of phenotype and carcass evaluation and lean cuts analysis of progeny, classified in accordance with grade of sire

4. Heritability of characteristics, and phenotypic and genetic correlations between characteristics ........................................................... 74

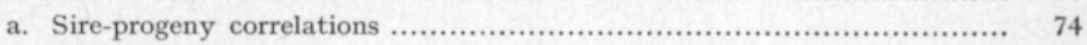

b. Heritability estimates ......................................................... 77

c. Phenotypic and genetic relations between characteristics ….............. 78

5. Investigations on the improvement of station testing of boars ................... 83

a. Phenotype and carcass characteristics as indicators of meatiness of carcass 83

b. Potential for early selection of boars ..................................... 88

c. Leg strength of boars on abundant feeding ................................... 92

d. Additional information from barrow sibs in assessment of breeding value

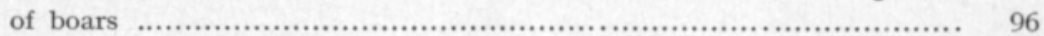

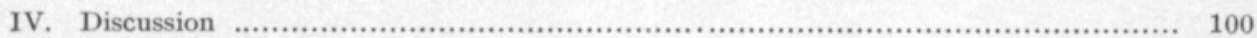

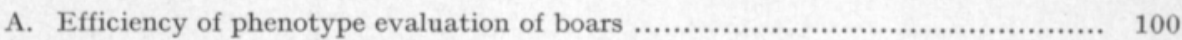

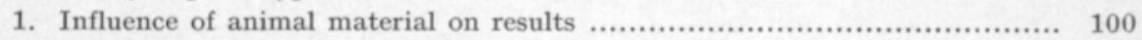

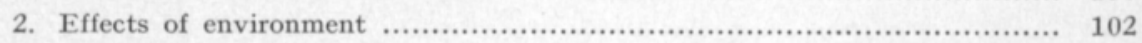

3. Heritability estimates of, and phenotypic correlations between, characteristics 103

B. Appraisal of means for the improvement of station testing of boars ................ 104

1. Potential for early selection of boars .......................................... 104

2. Leg strength of boars on various levels of feeding ............................... 105

3. Predicting carcass quality from results of phenotype testing ................... 106

4. Additional information about variation in boars' carcass quality from barrow

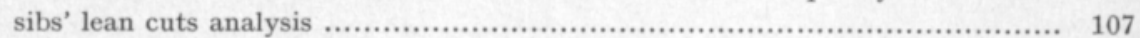

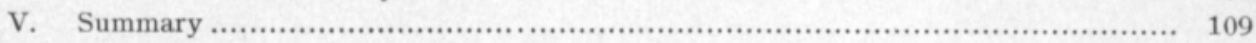

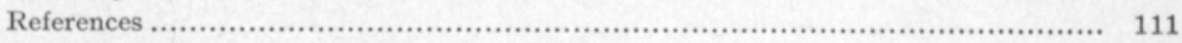

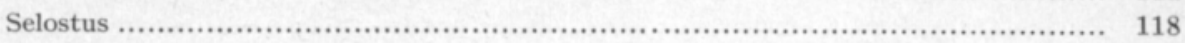




\title{
EtTAla, Elsi 1973. Boars for breeding: a study of methods of evaluation used at testing stations. J. Scient. Agric. Soc. Finl. 45: 00-000.
}

\begin{abstract}
The phenotype testing of highly selected boars was studied. Two groups, each of 30 boars, were tested centrally at stations for growth rate and ultrasonically measured fat thickness. According to test points, made up of a combination of these two traits, the 5 best boars, 5 average boars and the 5 poorest boars where selected for progeny evaluation. In all 26 boars and 441 progeny were tested.

The progeny evaluation showed that ultrasonic measurement of the fat thickness of the boars gave a very reliable estimate of the meatiness of their progeny. Those boars, as a group, giving the poorest carcass quality could be distinguished with statistical reliability from the other groups.

The correlations between sires and progeny were significant for both daily gain (period $20-88 \mathrm{~kg}$ ) and feed efficiency. The importance of rate of growth and feed efficiency has been neglected in selection for breeding as the test points used for the selection of boars depended almost entirely on fat thickness.

More than $30 \%$ of both boars and progeny boars suffered from some form of difficulty in walking. $13 \%$ of the boars were eliminated because of leg faults. Leg faults in progeny were mainly inherited or caused through injury.

A phenotype evaluation of progeny boars accounts much more effectively for the variation in their carcass value than does a full barrow sib evaluation alone. For best results, a progeny boar phenotype evaluation should be combined with a full barrow sib evaluation.
\end{abstract}

\section{Introduction}

Theoretical calculations show that for highly heritable traits $(\mathrm{h}>0.25)$ phenotype testing of pigs produces more rapid genetic progress than does progeny or full sib evaluation (HARTMANN and FEwSON 1967, Jonsson $1971 \mathrm{~b}$, Kirsch et al. 1962, Lush 1947, Standal 1968). The brevity of the generation cycle, the possibility of selection prior to breeding and the extensive range of selection are benefits provided by phenotype testing. Consequently, phenotype testing has rapidly gained ground, particularly after the introduction of ultrasonic measurement made it possible to evaluate the meat and fat contents of live animals. 
In on-the-farm testing, attention is paid mostly to determining the thickness of the fat or, in some countries, to determining the cross-sectional area of the longissimus dorsii muscle. Attention to growth and feed utilisation has been relegated to second place, for such characteristics are difficult to determine with reliability under varying farm conditions. Consequently boars are to an increasing extent tested at stations, in order to ascertain these economically very important characteristics and to increase the reliability of carcass evaluation. The method of regular station testing of boars has thus been adopted in many countries. Interest has also increased in a concurrent sib evaluation in which the sibs of the boars are tested under experiment station conditions (Blendl 1970, Kalm 1972, Moen 1972).

The number of boars tested at stations is generally low in comparison with the number tested on farms. It is the objective of station testing to produce superior boars to be used as parents of the next generation and in AI (artificial insemination). In central testing of boars, originating from the best parents, the differences between the boars are minimal. In order to measure these differences it is necessary to ensure that the genetic characteristics of the boars are fully expressed. A requirement for this is believed to be abundant feeding which, however, is usually avoided in testing, because of the leg weaknesses often encountered. Inaccuracies in the ultrasonic measuring of very thin layers of fat, health disorders during growth, differing rearing conditions of the piglets and other environmental factors may mask any significant differences among the boars and render an expensive station test worthless. Moreover, progress in breeding depends also upon the reliability of the criteria or indices used in selection.

The present study was carried out in 1967-1972 to determine the value of station tests of boars and to establish what factors influence the success of the tests.

The major subjects of the study were:

1) The selection results of the testing stations, as evaluated through progeny testing.

2) The heritability of the growth and carcass characteristics, and their phenotypic and genetic associations.

3) The influence of environmental factors in testing the individual animal.

4) Studies for the improvement of station testing:

a) Phenotype test and carcass measurements as indicators of the meatiness and fat layer of the carcass,

b) possibilities of early selection of boars,

c) leg strength of boars on a high plane of nutrition, and

d) additional information on the breeding value of boars as provided by castrated sibs. 


\section{Review of literature}

\section{A. Ultrasonic measurement of the fat thickness and the meatiness of live pigs}

1. Accuracy

As far as known, the principle of ultrasonic reflection in predicting the carcass quality of pigs was first used by the Pig Marketing Board in England in 1954. The technique of ultrasonic measurement obtained wider publicity in 1956 at a demonstration to the Commission on Pig Production of the European Association for Animal Production (LAuprecht 1960).

The mechanical measurement of fat (live probe) was developed slightly earlier (HAzEL and KLINE 1952), and the use of the electrical probe as a gauge for fat at roughly the same time (ANDREws and WhALEY 1955). These methods of determination, however, have not gained such popularity in Europe as has ultrasonic measurement.

Early studies showed that a good estimate of the thickness of the fat of pigs could be obtained through ultrasonic measurement (DumonT 1957, ref. Lauprecht 1960, Kliesch et al. 1957, Lauprecht et al. 1957, Price et al. 1958), the accuracy of which has subsequently been the subject of a great deal of study. The precision has been checked by repeated ultrasonic measurements at the same point, and the accuracy by comparing the results with the respective measurements obtained from the carcasses (Table 1). The most common positions for ultrasonic measurement have been the rear of the shoulder blade, the midback and the loin, along the midline of the back. The places of measurement of the side fat have varied a great deal (Table 1).

The repeatability of ultrasonic fat measurements obtained in various studies varies between 0.41 and 1.00 , and the correlation coefficients with the carcass measurements between 0.39 and 0.95 (Table 1). The absolute differences between the ultrasonic measurements of fat and the measurements of the carcass have usually been under $2 \mathrm{~mm}$ (CLAUSEN 1959, LAUPRECHT et al. 1957, Peter 1962, Rittler et al. 1964, Rittler 1968 a, b, SkJervold 1962). The accuracy of the ultrasonic measurement has depended primarily on the location of the fat and muscle layers at the various points of measurement, the skill of the operator, the movements and position of the animal at the momet of measurement, and whether the points of measurement were marked and the control measurements made in exactly the same spot. 
To allow for the between-animal variation in the distribution of the fat layers, it has been recommended that ultrasonic measurement be made at 3-5 positions (Gerlach 1967, 1970, Lauprecht et al. 1965, Rittler 1964, 1968 a, b, Schoen 1962, Scholz 1965). Measurements on both sides of the animal, as opposed to measurements on one side only, do not markedly improve the reliability of the results (Horst 1964, Rittler et al. 1964, Schoen 1962), nor do a large number of measurements made at the same place (GERLACH 1967, LAuprecht et al. 1965, Rittler 1964, 1968 a, Rittler et al. 1964, Schoen 1962).

Table 1. Accuracy of ultrasonic measurement of fat thickness in live pigs: repeatability, and correlation with carcass measurements.

\begin{tabular}{|c|c|c|c|c|}
\hline Source & $\begin{array}{l}\text { Number } \\
\text { of pigs }\end{array}$ & $\begin{array}{l}\quad \text { Location } \\
(\mathrm{MB}=\text { midline of back })\end{array}$ & Repeatability & $\left.\mathbf{r}^{\mathbf{1}}\right)$ \\
\hline Clausen (1959) & - & MB, 3 points & & $0.79-0.89$ \\
\hline GERLACH (1967) & 163 & $\begin{array}{l}6-8 \mathrm{~cm} \text { from } \mathrm{MB}, \\
1-5 \text { points, } 1-3 \text { repeats }\end{array}$ & $0.96-1.00$ & \\
\hline HAZEL \& KLINE (1959) & 56 & $5 \mathrm{~cm}$ from $\mathrm{MB}, 3$ points & & $0.66-0.70$ \\
\hline Hofmann \& Peter & 109 & MB, 3 points & & $0.91-0.93$ \\
\hline \multirow[t]{2}{*}{ (1964) } & 109 & $90^{\circ}$ to MB at midback, 2 points & & $0.88-0.90$ \\
\hline & 109 & Haunch, 3 points & & $0.77-0.91$ \\
\hline \multirow{2}{*}{$\begin{array}{l}\text { HoRST }(1964) \\
\text { KLIESCH \& HoRST } \\
(1961)\end{array}$} & 44 & $6 \mathrm{~cm}$ from MB on both sides & 0.92 & \\
\hline & $\begin{array}{l}44 \\
30\end{array}$ & $\begin{array}{l}5 \text { and } 10 \mathrm{~cm} \text { from } \mathrm{MB}, 5 \text { repeats } \\
5,8 \text { and } 10 \mathrm{~cm} \text { from } \mathrm{MB} \\
1 \text { repeat }\end{array}$ & $0.74-0.90$ & \\
\hline \multirow{2}{*}{ LAUPRECHT et al. (1965) } & 132 & $\mathrm{MB}, 1-5$ points, $1-2$ repeats & $0.49-0.84$ & \\
\hline & 132 & $\begin{array}{l}6 \mathrm{~cm} \text { from } \mathrm{MB}, 1-5 \text { points, } \\
1-2 \text { repeats }\end{array}$ & $0.61-0.90$ & \\
\hline MENNERICH (1967) & 228 & MB, 3 points & $0.58-0.81$ & \\
\hline Otтo \& SIEG (1963) & 109 & MB, 3 points & & 0.92 \\
\hline Peter (1962) & 30 & $\mathrm{MB}, 3$ & & $0.54-0.89$ \\
\hline \multirow[t]{2}{*}{ Price et al. (1960) } & 74 & MB, 3 & & 0.82 \\
\hline & 84 & $\mathrm{MB}, 3$ & & 0.88 \\
\hline RITTLER (1964) & 152 & $\begin{array}{l}6-8 \mathrm{~cm} \text { from } \mathrm{MB}, \\
1-5 \text { points, } 1-3 \text { repeats }\end{array}$ & $0.72-0.93$ & \\
\hline$+(1968 \mathrm{a})$ & 392 & $6 \mathrm{~cm}$ from $\mathrm{MB}, 5$ points & 0.98 & \\
\hline$-(1968 \mathrm{~b})$ & 82 & $6 \mathrm{~cm}$ from MB, 5 points & 0.96 & \\
\hline RitTler et al. (1964) & 35 & $\begin{array}{l}6-8 \mathrm{~cm} \text { from MB, one or both } \\
\text { sides, } 1-5 \text { points, } 1-3 \text { repeats }\end{array}$ & $0.41-0.86$ & \\
\hline SchoеN (1962) & 100 & $\begin{array}{l}7 \mathrm{~cm} \text { from MB, one or both } \\
\text { sides } 1-6 \text { points, } 1-6 \text { repeats }\end{array}$ & $0.71-0.95$ & 0.85 \\
\hline Scholz (1965) & 563 & MB, 3 points & & $0.39-0.52$ \\
\hline SKÅRMAN (1960) & $\begin{array}{l}120 \\
120\end{array}$ & $\begin{array}{l}\mathrm{MB}, 3 \\
90^{\circ} \text { to } \mathrm{MB} \text { at midback }\end{array}$ & & $\begin{array}{l}0.55-0.71 \\
0.64\end{array}$ \\
\hline SKJERVOLD et al. (1960) & 320 & MB, 3 points & & $0.47-0.68$ \\
\hline \multirow[t]{2}{*}{ SUNDGREN (1969) } & 190 & MB, 3 points & & $0.49-0.95$ \\
\hline & 190 & $8 \mathrm{~cm}$ from $\mathrm{MB}$ at midback & & $0.73-0.75$ \\
\hline \multirow[t]{3}{*}{ UUSISALMI (1969 a) } & 236 & MB, 3 points & & $0.56-0.76$ \\
\hline & 236 & 3,6 and $9 \mathrm{~cm}$ from $\mathrm{MB}$ & & $0.64-0.75$ \\
\hline & 236 & $8 \mathrm{~cm}$ from $\mathrm{MB}$ & & 0.79 \\
\hline \multirow[t]{2}{*}{ VOCKERT (1969) } & 95 & MB, 4 points & $0.76-0.90$ & $0.49-0.58$ \\
\hline & 95 & $6-8 \mathrm{~cm}$ from MB, 3 points & $0.87-0.94$ & $0.51-0.59$ \\
\hline \multirow[t]{2}{*}{ WENIGER et al. (1967) } & 101 & MB, 3 points & & 0.55 \\
\hline & 101 & $90^{\circ}$ to $\mathrm{MB}$ at midback & & 0.58 \\
\hline
\end{tabular}

1) $\mathbf{r}=$ coefficient of correlation between thickness of fat in live animal measured ultrasonically and thickness of fat measured on carcass. 
Table 2. Accuracy of ultrasonic determination of thickness or area of cross-section of the longissimus muscle in live pigs: repeatability, and correlation with carcass measurements.

\begin{tabular}{|c|c|c|c|c|}
\hline Source & $\begin{array}{l}\text { Number } \\
\text { of pigs }\end{array}$ & $(\mathrm{MB}=$ Location & Repeatability & $\left.\mathbf{r}^{1}\right)$ \\
\hline \multirow[t]{2}{*}{ AssAdI (1967) } & 163 & Meat area, ultrasonograph ${ }^{2}$ ) & 0.67 & 0.60 \\
\hline & 146 & Fat area ultrasonograph ${ }^{2}$ ) & 0.77 & 0.46 \\
\hline \multirow[t]{2}{*}{ Diekmann (1960) } & 102 & Meat area $^{2}$ ) & & 0.19 \\
\hline & 102 & Fat area $^{2}$ ) & & 0.16 \\
\hline GERLACH (1967) & 163 & $\begin{array}{l}\text { Thickness of muscle } 6-8 \mathrm{~cm} \\
\text { from MB, } 1-5 \text { points, } 1-3 \\
\text { repeats }\end{array}$ & $0.92-0.99$ & \\
\hline Horst (1964) & 44 & $\begin{array}{l}\text { Thickness of muscle } 6 \mathrm{~cm} \\
\text { from MB on both sides }{ }^{2} \text { ) }\end{array}$ & 0.78 & \\
\hline \multirow[t]{4}{*}{$-(1969)$} & 98 & $\begin{array}{l}\text { Meat area, midback and rump, } \\
\text { ultrasonograph }\end{array}$ & & 0.59 \\
\hline & 98 & Fat area, ultrasonograph & & 0.93 \\
\hline & 30 & Meat area, ultrasonograph & & 0.61 \\
\hline & 30 & Fat area, ultrasonograph & & 0.89 \\
\hline$-(1971)$ & 120 & $\begin{array}{l}\text { Meat area, one or both sides, } \\
1-4 \text { repeats, ultrasonograph }\end{array}$ & $0.56-0.88$ & \\
\hline $\begin{array}{l}\text { KLIESCH \& HORST } \\
(1961)\end{array}$ & $\begin{array}{l}44 \\
30\end{array}$ & $\begin{array}{l}\text { Thickness of muscle } 5-10 \mathrm{~cm} \\
\text { from MB, } 5 \text { repeats }^{2} \text { ) } \\
\text { Thickness of muscle } 5,8 \text { and }\end{array}$ & $0.66-0.85$ & \\
\hline \multirow[t]{4}{*}{ LAUPRECHT et al. (1960) } & 85 & $\begin{array}{l}10 \mathrm{~cm} \text { from MB, } 1 \text { repeat } \\
\text { Meat } \text { area }^{3} \text { ) }\end{array}$ & $0.91-0.96$ & 0.77 \\
\hline & 85 & Fat area $^{3}$ ) & & 0.46 \\
\hline & 47 & Meat area $^{3}$ ) & & 0.63 \\
\hline & 47 & Fat area $^{3}$ ) & & 0.64 \\
\hline \multirow[t]{2}{*}{$-(1965)$} & 132 & Thickness of muscle $6 \mathrm{~cm}$ from & & \\
\hline & & $\begin{array}{l}\text { MB, } 1-5 \text { points, } 1-2 \text { repeats } \\
\text { Thickness of muscle } 90^{\circ} \text { to } \mathrm{MB}\end{array}$ & $0.25-0.71$ & \\
\hline Mennerich (1967) & 228 & at midback, 3 points $^{2}$ ) & $0.21-0.61$ & \\
\hline Otтo \& Sieg (1963) & 108 & $\begin{array}{l}\text { Thickness of muscle at MB, } \\
3 \text { points }\end{array}$ & & 0.62 \\
\hline RITTLER (1964) & 152 & $\begin{array}{l}\text { Thickness of muscle } 6-8 \mathrm{~cm} \\
\text { from midback, } 1-5 \text { points, } \\
1-3 \text { repeats }\end{array}$ & $0.40-0.86$ & \\
\hline$-(1968 \mathrm{~b})$ & 82 & $\begin{array}{l}\text { Thickness of muscle } 6 \mathrm{~cm} \text { from } \\
\text { MB, } 5 \text { points }\end{array}$ & 0.78 & \\
\hline RITTLER et al. (1964) & 35 & $\begin{array}{l}\text { Thickness of muscle } 6-8 \mathrm{~cm} \\
\text { from MB, } 1-5 \text { points, } \\
1-3 \text { repeats } \\
\text { Meat area, } 1-3 \text { repeats } \\
\text { Fat area, } 1-3 \text { repeats }\end{array}$ & $\begin{array}{l}0.48-0.88 \\
0.91-0.97 \\
0.93-0.98\end{array}$ & \\
\hline \multirow[t]{3}{*}{ SCHOEN (1962) } & 100 & $\begin{array}{l}\text { Thickness of muscle, one or } \\
\text { both sides, } 1-6 \text { repeats }^{3} \text { ) } \\
\text { Meat area one or both sides, }\end{array}$ & $0.78-0.99$ & 0.41 \\
\hline & 100 & $\begin{array}{l}\text { Meat area one or both sides, } \\
1-6 \text { repeats }^{3} \text { ) }\end{array}$ & $0.70-0.98$ & 0.59 \\
\hline & 100 & $\begin{array}{l}\text { Fat area one or both sides } \\
\left.1-6 \text { repeats }^{3}\right)\end{array}$ & $0.86-0.99$ & 0.57 \\
\hline \multirow[t]{2}{*}{ StoufFer et al. (1961) } & 42 & $\begin{array}{l}\text { Thickness of muscle, ultra- } \\
\text { sonograph }{ }^{2} \text { ) }\end{array}$ & & 0.47 \\
\hline & 42 & Meat area, ultrasonograph ${ }^{2}$ ) & & 0.70 \\
\hline UUSISALMI (1971 b) & 236 & $\begin{array}{l}\text { Thickness of muscle, } 3,6 \text { and } \\
9 \mathrm{~cm} \text { from } \mathrm{MB}, 3 \text { points })\end{array}$ & & $0.03-0.28$ \\
\hline VOCKERT (1969) & 95 & $\begin{array}{l}\text { Thickness of muscle } 6-8 \mathrm{~cm} \\
\text { from MB, } 3 \text { points }\end{array}$ & $0.78-0.82$ & $0.35-0.49$ \\
\hline
\end{tabular}

1) $\mathbf{r}=$ coefficient of correlation between thickness or area of cross-section of longissimus muscle measured ultrasonically and corresponding measurements made on carcass.

$\left.{ }^{2}\right)$ Measured between 13th and 14th rib.

3) Measured between last and last-but-one rib.

4) Measured behind last rib. 
In Finland the ultrasonic measurement of fat thickness has usually been carried out in accordance with Swedish practice (SUNDGREN 1965, 1967, 1969). In 1965-68 the measurements were taken along the midline of the back at the withers, the midback and the loin. Since 1968 measurements have been made at the midback and at a distance of about $8 \mathrm{~cm}$ on either side of the midback (see Fig. 1); the change was made after tests performed in Sweden and Finland had shown that the new method gives improved results (SUNDGREN 1964, 1967); Uusisalmi's findings were published later (1969 a, 1971 b).

The thickness and cross-sectional area of the longissimus muscle are more difficult to determine by ultrasonic methods than the thickness of the fat layers. Series of ultrasonic mesurements made close to the longissimus muscle are used to construct a cross-sectional diagram of this muscle and its overlaying fat. Reported repeatabilities of the measurements of muscle area, and the correlation with carcass measurements, have varied considerably (Table 2). The use of several locations of measurement and repeated measurement at the same position have improved the reliability in the determination of muscle thickness, but not in the determination of muscle area (LAuprecht et al. 1965, Mennerich 1967, Rittler 1964, Rittler et al. 1964). If the appropriate equipment is available, an ultrasonic picture of the site of measurement can be used to improve the reliability of the ultrasonic measurements (AssAdi 1967, Horst 1969, 1971, Kliesch and Horst 1962, Stouffer et al. 1961). The relative contributions of muscle and fat to the cross-sectional diagram, obtained by the series of ultrasonic measurements mentioned above, permit calculation of the expected fat: meat ratio of the carcass. The ratio is generally closely correlated with the ratio found by direct measurement on the carcass $(r=0.41-0.94)$ (Assadi 1967, Diekmann 1960, Horst 1969, Lauprecht et al. 1960, Schoen 1962).

2. Fat thickness and cross-sectional area of $l$ o $n g$ is $i m u s$ muscle as indicators of meatiness and fat content of carcass

The whole purpose in measuring the fat layers and longissimus muscle of the live pig is to quantitate the meatiness and fat content of the main part of the carcass obtained at slaughter. The value of these two measurements as indicators of carcass characteristics has been tested by correlating them with the weights of lean cuts obtained from the carcass; measurements made on the longitudinally sectioned carcass have been evaluated in the same way (Tables 3 and 4). As regards fat thickness, ultrasonics data and carcass section data are both well correlated with the lean cuts results (Table 3). With regard to longissimus area, however, the ultrasonics-versus-lean cuts correlation is not as good as the carcass section-versus-lean cuts correlation (Table 4). According to Horst (1971), recent developments in ultrasonics have made a measure of the muscle obtained by this technique as reliable as that obtained directly from the carcass, in the evaluation of the meatiness of the carcass.

Measurements of side fat have proved to be the best indicators in predicting carcass quality in a number of studies (FEnder 1962, Hoffmann and Peter 
Table 3. Correlation of fat thickness, measured ultrasonically on the live animal or determined directly on the longitudinally-sectioned carcass, with proportion of lean cuts and fat cuts obtained from carcass.

\begin{tabular}{|c|c|c|c|c|c|c|}
\hline \multirow{2}{*}{ Source } & \multirow{2}{*}{$\begin{array}{c}\text { Number } \\
\text { of } \\
\text { pigs }\end{array}$} & \multirow{2}{*}{ Ultrasonic measurement } & \multicolumn{4}{|c|}{ Correlation coefficient, $r$} \\
\hline & & & $\%$ lean & cuts & $\%$ fat cuts & $\begin{array}{l}\text { longissimus } \\
\text { muscle area }\end{array}$ \\
\hline GERWIG (1965 a) & 205 & Fat, $2-3$ points & -0.42 to & $\left.-0.56^{2}\right)$ & & \\
\hline $\begin{array}{l}\text { HAZEL \& KLINE } \\
\text { (1959) }\end{array}$ & 56 & $\begin{array}{l}\text { Sidefat, } 5 \mathrm{~cm} \text { from midline } \\
\text { of back, } 3 \text { points }\end{array}$ & -0.90 & & & \\
\hline Hofmann \& Peter & 53 & Backfat, 3 points & -0.48 & & 0.62 & \\
\hline (1964) & 53 & $\begin{array}{l}\text { Sidefat, to side from mid- } \\
\text { back, } 2 \text { points }\end{array}$ & -0.57 & & 0.76 & \\
\hline $\begin{array}{l}\text { LAUPRECHT et al. } \\
\text { (1965) }\end{array}$ & $\begin{array}{l}132 \\
132\end{array}$ & $\begin{array}{l}\text { Backfat, } 3 \text { points } \\
\text { Sidefat } 6 \mathrm{~cm} \text { from midline }\end{array}$ & -0.27 & & 0.47 & \\
\hline & & of back, 3 points & -0.50 to & -0.56 & $0.61-0.66$ & \\
\hline MENNERICH (1967) & $\begin{array}{l}101 \\
101\end{array}$ & $\begin{array}{l}\text { Backfat, } 3 \text { points } \\
\text { Sidefat, to side from mid- } \\
\text { back, } 3 \text { points }\end{array}$ & $\begin{array}{l}-0.23 \\
-0.37\end{array}$ & 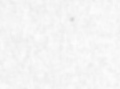 & $\begin{array}{l}0.51 \\
0.68\end{array}$ & \\
\hline Peter (1962) & 30 & Backfat, 3 points & & & & -0.60 \\
\hline PRICE et al. (1960) & 74 & $\begin{array}{l}\text { Sidefat } 3.8 \mathrm{~cm} \text { from mid- } \\
\text { line of back, } 3 \text { points }\end{array}$ & -0.70 & & & -0.33 \\
\hline SchoEN (1962) & $\begin{array}{l}84 \\
97\end{array}$ & $\begin{array}{l}\text { Sidefat } 7 \mathrm{~cm} \text { from midline } \\
\text { of back, one or both sides, } \\
3 \text { points }\end{array}$ & -0.65 & & 0.69 & \\
\hline SUNDGREN (1969) & $\begin{array}{l}190 \\
190\end{array}$ & $\begin{array}{l}\text { Backfat, } 3 \text { points } \\
\text { Sidefat } 8 \mathrm{~cm} \text { from midline }\end{array}$ & -0.15 to & -0.43 & $0.15-0.55$ & \\
\hline UUSISALMI (1971 b) & 236 & $\begin{array}{l}\text { of back } \\
\text { Sidefat } 3-9 \mathrm{~cm} \text { from mid- } \\
\text { line of back, } 4 \text { points }\end{array}$ & -0.55 to & -0.57 & $0.61-0.66$ & -0.33 to -0.43 \\
\hline & & Carcass section measuremen & & & & \\
\hline CRoss et al. (1970) & 43 & Fat, $3-5$ points & -0.59 to & -0.62 & $0.72-0.74$ & \\
\hline GERWIG (1965 a) & 205 & Fat, $2-3$ points & -0.38 to & $\left.0.43^{2}\right)$ & & \\
\hline $\begin{array}{l}\text { HAzEL \& KLINE } \\
\text { (1952) }\end{array}$ & 96 & Fat, 4 points & -0.45 & & & -0.41 \\
\hline$-(1959)$ & 56 & Fat, 3 points & -0.85 & & & \\
\hline $\begin{array}{l}\text { HoLLAND \& HAZEL } \\
\text { (1958) }\end{array}$ & 105 & Fat, 8 points & -0.72 & & 0.81 & -0.29 \\
\hline $\begin{array}{l}\text { KLINE \& GolL } \\
(1964)\end{array}$ & 50 & Fat, 8 points & & & & -0.35 to -0.47 \\
\hline $\begin{array}{l}\text { LAUPRECHT et al. } \\
\text { (1965) }\end{array}$ & 132 & Backfat, 3 points & -0.31 & & 0.50 & \\
\hline MENNERICH (1967) & $\begin{array}{l}101 \\
101\end{array}$ & $\begin{array}{l}\text { Backfat, } 3 \text { points } \\
\text { Sidefat, to side from } \\
\text { midback }\end{array}$ & -0.35 & & 0.54 & \\
\hline MÜLLER-HAYE & 78 & Backfat, 3 points & $\begin{array}{l}-0.34 \\
-0.73\end{array}$ & & 0.77 & \\
\hline (1965) & 78 & Sidefat & -0.77 & & 0.79 & \\
\hline $\begin{array}{l}\text { PEARSON et al. } \\
\text { (1958 a) }\end{array}$ & 195 & Fat & -0.68 & & & \\
\hline$-(1958 \mathrm{~b})$ & 195 & , & -0.47 & & & \\
\hline$-(1959)$ & 292 & - & -0.80 & & & -0.50 \\
\hline Pedersen (1968) & $\begin{array}{l}320+356 \\
320+356\end{array}$ & $\begin{array}{l}\text { Backfat, } 3 \text { points } \\
\text { Sidefat }\end{array}$ & $\begin{array}{l}-0.33 \text { to } \\
-0.64 \text { to }\end{array}$ & $\begin{array}{l}-0.63 \\
-0.71\end{array}$ & & \\
\hline PETER (1962) & 30 & Backfat, 3 points & & & & -0.78 \\
\hline PRICE et al. (1960) & $\begin{array}{l}74 \\
84\end{array}$ & Fat, 3 points & $\begin{array}{l}-0.74 \\
-0.80\end{array}$ & & & \\
\hline RITTLER et al. & 228 & Backfat & -0.38 & & 0.43 & \\
\hline (1965) & 228 & Sidefat & -0.45 & & 0.49 & \\
\hline SUNDGREN (1969) & $\begin{array}{l}190 \\
190\end{array}$ & $\begin{array}{l}\text { Backfat, } 3 \text { points } \\
\text { Sidefat } 8 \mathrm{~cm} \text { to side }\end{array}$ & $\begin{array}{l}-0.20 \text { to } \\
-0.43 \text { to }\end{array}$ & $\begin{array}{l}-0.48 \\
-0.49\end{array}$ & $\begin{array}{l}0.23-0.50 \\
0.64-0.66\end{array}$ & \\
\hline UUSISALMI (1971 a) & 153 & Sidefat & -0.57 & & 0.73 & \\
\hline $\begin{array}{l}\text { ZOBRISKY et al. } \\
\text { (1959) }\end{array}$ & 207 & Backfat, 3 points & & & 0.67 & \\
\hline
\end{tabular}

1) Reported methods of obtaining lean cuts vary slightly.

2) Results expressed in weight units, not \% units. 
Table 4. Correlation between the cross-sectional area of the longissimus muscle, measured ultrasonically on the live animal or directly on the longitudinally sectioned carcass, and \% lean cuts and $\%$ fat cuts.

\begin{tabular}{|c|c|c|c|c|}
\hline Source & $\begin{array}{l}\text { Number } \\
\text { of pigs }\end{array}$ & $\begin{array}{c}\text { Ultrasonic } \\
\text { measurement of muscle area }\end{array}$ & $\begin{array}{c}\% \\
\text { lean cuts }\end{array}$ & $\begin{array}{c}\% \\
\text { fat cuts }\end{array}$ \\
\hline Diekmann (1960) & 102 & between ribs 13 and 14 & 0.41 & \\
\hline Horst (1971) & 111 & ultrasonograph 3 points & $0.17-0.42$ & \\
\hline $\begin{array}{l}\text { LAUPRECHT et al. } \\
\text { (1965) }\end{array}$ & 132 & $3-5$ points & $0.36-0.42$ & -0.29 to -0.42 \\
\hline Mennerich (1967) & 101 & between ribs 13 and 14 & 0.16 & -0.34 \\
\hline SCHOEN (1962) & 97 & $\begin{array}{c}\text { Carcass section } \\
\text { measurement of muscle area }\end{array}$ & 0.32 & -0.28 \\
\hline CRoss et al. (1970) & 43 & & 0.48 & -0.37 \\
\hline Horst (1971) & 111 & 2 points & $0.50-0.52$ & \\
\hline $\begin{array}{l}\text { KLINE \& HAZEL } \\
(1965)\end{array}$ & 23 & $\begin{array}{l}\text { between last and last- } \\
\text { but-one rib }\end{array}$ & 0.65 & \\
\hline & 23 & behind rib 10 & 0.66 & \\
\hline $\begin{array}{l}\text { LAUPRECHT et al. } \\
\text { (1965) }\end{array}$ & 132 & between ribs 13 and 14 & 0.60 & -0.50 \\
\hline MENNERICH (1967) & 101 &,. & 0.69 & -0.51 \\
\hline $\begin{array}{l}\text { MÜLLER-HAYE } \\
(1965)\end{array}$ & 78 & $\rightarrow, \quad$, & 0.59 & -0.53 \\
\hline $\begin{array}{l}\text { PeArson et al. } \\
\text { (1956 b) }\end{array}$ & 102 & $\begin{array}{l}\text { between last and last- } \\
\text { but-one rib }\end{array}$ & 0.53 & \\
\hline & 102 & behind rib 10 & 0.52 & \\
\hline Pedersen (1968) & $320+356$ & $\begin{array}{l}\text { between last and last- } \\
\text { but-one rib }\end{array}$ & $0.30-0.49$ & \\
\hline Price et al. (1960) & 84 & behind rib 10 & 0.62 & \\
\hline $\begin{array}{l}\text { RITTLER et al. } \\
(1965)\end{array}$ & 228 & & 0.43 & -0.40 \\
\hline UUSISALMI (1971 c) & 97 & behind last rib & 0.61 & : \\
\hline
\end{tabular}

1964, Mennerich 1967, Rittler et al. 1965, Sundgren 1969), despite the rather variable results reported earlier (BUCK et al. 1962, HAZEL and KLINE 1952, RoBison et al. 1960). When carcass meatiness was determined by ultrasonic measurement of both fat and longissimus muscle, the muscle data added little to the value of the fat data (LAUPREcht et al. 1965, Schoen 1962, UusiSALMI $1971 \mathrm{~b})$.

\section{B. Rate of growth and feed efficiency as criteria in the phenotype testing of boars}

The rate of growth of boars is easily determined by weighing, and the feed efficiency by controlled feeding of the individual animals. However, little account has been taken of such characteristics in phenotype evaluation. The varying conditions of on-farm testing make it difficult to produce comparable results (FLOCK et al. 1970, MENNERICH 1967). In station testing consideration of rate of growth and feed efficiency have depended on the selection indices 
used and the absolute results on the feeding standards practised (BLENDL 1970, Ettala 1971 a, b, Fewson et al. 1962, Minkema et al. 1964, Persson and LINDHÉ 1972).

StANDAL $(1962)$ and Sundgren $(1965,1967)$ have quantitated the relationships between weight and age, making it possible to compare animals of different age. Attempts have been made to reduce differences due to environmental conditions by combining the growth and fat data. Growth nomograms prepared by Sundgren have been used in Finland (Figures 3 and 5 ), and the selection of boars at farms and testing stations has been made in accordance with test points calculated from growth and fat data (Anon. 1968). The rate of growth, however, has accounted for only a very small part of the variation in test points, i.e. $9.2 \%$ for boars tested at stations in Finland in 1965-68, while the thickness of the fat has accounted for $\mathbf{8 5 . 2} \%$ of the variation (ETTALA $1971 \mathrm{~b})$. Moen (1968) reported that rate of growth and feed efficiency together account for more than $20 \%$ of the variation in a Norwegian index. In Sweden the system of test points has been abandoned in favour of a station index, in which the importance of feed efficiency is emphasised (PERsson and Lindhé 1972). In Finland feed efficiency has not been as a separate directly taken into account; the association with growth rate was analysed by ETTALA (1971 b).

The interrelationships between characteristics naturally have a bearing upon their usefulness in selection and breeding. There are very close phenotypic and genetic correlations $\left(r_{p}\right.$ ranges from -0.49 to -0.92 and $r_{g}$ from -0.57 to -1.02 ) between rate of growth and feed efficiency (BIEDERMAnN 1971, Flock 1970, Jonsson 1963, Krippl et al. 1965, Langholz 1966, Persson and Lindhé 1972, Schmitten 1967, Varo 1962, Zagozen and Schröder 1970). Evidently these figures are due in part to auto-correlation, for rapid attainment of final weight requires improvement of both rate of growth and feed efficiency (Biedermann 1971, Jonsson 1963, Krippl et al. 1965, SchmitTEN 1967).

According to some studies, are of growth and feed efficiency are positively genetically correlated with low fat-thickness and meatiness, i.e. meaty pigs with a thin layer of fat grow rapidly and have a good feed efficiency. In these studies the correlation coefficient between rate of growth and fat thickness ranged from -0.31 to -0.68 , and that between rate of growth and area of longissimus muscle from +0.28 to +0.39 (BIEdermann 1971, Flock 1970, GERLACH 1967). The correlation coefficient $\left(\mathrm{r}_{\mathrm{g}}\right)$ between feed efficiency and (a) fat thickness is +0.20 to +0.79 , and (b) longissimus muscle area is -0.27 to -0.76 (Biedermann 1971, Ettala 1971 b, Flock 1970, Jonsson 1963, Krippl et al. 1965, Schmitten 1967). However, rate of growth and feed efficiency do not always correlate well with carcass characteristics (BUCHENauer 1970, Englisch 1969, Ettala 1971 b, Fewson et al. 1962, Langholz 1966, Mennerich 1967, Persson and Lindhé 1972, Scholz 1965, Wussow and Grosse 1959). The latter reports indicate that the assumption that growth and feed-utilisation characteristics of pigs would improve automatically when selection for breeding is made on the basis of low fat-thickness and meatiness is erroneous. Consequently it is important that rate of growth and feed efficiency be taken into account, at least when selecting boars for artificial insemination. 


\section{Effects of environmental factors on phenotype testing}

Phenotype evaluation is sensitive to environmental factors, which mainly affect rate of growth and feed efficiency, and only slightly meatiness (Horst 1969, Minkema et al. 1964, Persson and Lindhé 1972).

$\mathrm{F}$ e e d is one of the most important of the environmental factors (BLENDL 1970, Brunstad and Fowler 1959, Cole and Hardy 1971, Cook et al. 1972, Glodek et al. 1971, Lodge et al. 1972, Schierbaum 1961, Sundgren 1972). Feeding levels have varied from restricted to ad libitum (BLENDL 1970, ETTALA 1971 a, Fewson et al. 1962, Persson and Lindhé 1972, Minkema et al. 1964, ZAGOZEN and SCHRÖDER 1970). With pigs, individual feeding is preferred to group feeding, in order that both feed efficiency and rate of growth can be measured (Fredeen and Jonsson 1957, Hofmann 1965, Jonsson 1959).

The extent to which abundant feeding increases leg weakness is not yet known. A correlation between rapid growth and leg weakness was observed (Sснмір 1970), but leg weakness was common also among slow-growing boars on restricted feed. It has generally been necessary to eliminate $20-40 \%$ of boars under test because of this tendency (Ettala 1971 a, NebE 1969, Persson 1972, Wright 1967). Diet, genetic factors, lack of exercise and infection of leg injuries may play a part in causing leg weakness (GERwig 1965 b, Kangasniemi 1971 a, Melrose 1967, Smith 1966).

L ive-weight and f a t $\mathrm{thickness}$. Fat thickness as determined by ultrasonic measurement is closely related to live weight, so that live-weight corrections to the thickness data are required. The correction factors, which depend on breed, sex, position of measurement and desired testing weight, vary from 0.07 to $0.24 \mathrm{~mm} / \mathrm{kg}$ (ENGLisch 1969, GerLach 1967, GLOdEK 1964, Hofmann and Peter 1964, Hofmann et al. 1965, Langlet et al. 1968, Lauprecht et al. 1967, Lindhé and Sundgren 1969, Mennerich 1967, Otto and Sieg 1965, 1966, Rittler 1964, 1968 a, Schumm et al. 1966, Uusisalmi 1971 d). The relationship between fat thickness and live weight is linear or almost linear (Gerlach 1967, Hofmann and Peter 1964, Lauprecht et al. 1967, Mennerich 1967, Quijandria and Robison 1971, Rittler 1964, 1968 a). If the fat is measured at a live weight close to a predetermined value, the effect of live weight upon the results is not significant (UUSISALmi 1971 b). The thickness of the longissimus muscle and the fat-to-meat ratio calculated from the ultrasonic measurements are not closely related to live weight (AssADI 1967, Gerlach 1967, Horst 1969, Lauprecht et al. 1967, Mennerich 1967, Rittler 1964, 1968 a).

Age and fat thickness. According to the studies cited above, consideration of the age of the animal, in addition to its weight, at the time of ultrasonic measurement does not improve the accuracy of the results; these findings contrast with those of Ettala (1971 a), Plonka et al. (1969), QuiJANDRIA and Robison (1971), Robison (1962) and SKJERVOLD et al. (1960). Using points scales for fat thickness evaluation, STANDAL (1962) corrected for both age and weight; SUNDGREN (1965) made a correction for age only, but later (SUNDGREN 1967) corrected for weight only (Figures 4 and 6 are examples of Sundgren's points scales). 
The effects of the in it ia l weight a n d a g e on the test results have been determined in many progeny trials. Pigs that have reached the required starting weight at a normal age usually grow slightly faster during the testing period than pigs that have reached this weight at an earlier age (Jonsson 1963, Langholz 1965, Persson and Lindhé 1972, Scholz 1965). The effects of starting age on feed efficiency and carcass characteristics are slight; both positive and negative effects have been reported (Buchenauer 1970, Jonsson 1963, LAngholz 1965, Persson and Lindhé 1972).

$\mathrm{S}$ e a s o n a 1 ef $\mathrm{fects}$ on the rate of growth, feed efficiency and carcass quality have been studied in progeny and phenotype tests, and conflicting results have been obtained. Biedermann (1971), Buchenauer (1970), Fredeen and Jonsson (1957), Johansson and Korkmann (1950), Krippl et al. (1965), Persson and Lindhé (1972), Rittler (1968 b) and Schmitten (1967) found that season had a significant effect on growth, feed efficiency or carcass characteristics, whereas Horst (1969), Langholz (1965), Mennerich (1967), Schmidt (1964) and Vockert (1969) found that season did not cause any systematic differences. This divergence in results is probably due to differences in rearing conditions. Particular attention should consequently be paid to the temperature and the ventilation of the animal sheds.

\section{Genetic factors in phenotype evaluation}

The accuracy of phenotype evaluation of boars has been studied by calculating heritabilities. Heritability $\left(\mathrm{h}^{2}\right)$ estimates have been calculated from half sib correlations for boars tested in the field or for their progeny reared at testing stations, and from regressions of boars tested in the field on their progeny tested either in the field or at a testing station (FLOCK et al. 1970, GLODEK 1964, Horst 1969, Langlet et al. 1968, Lauprecht et al. 1967, Mennerich 1967, Rittler 1964, 1968 a, b, Vockert 1969). In USA efficiency of phenotype selection was checked by selecting pigs for high and low fat thickness for 5 to $\mathbf{1 0}$ generations, and was comparing these with an unselected control strain (Berruecos et al. 1970, Gray et al. 1968, Hetzer and Harvey 1967). Fat thickness was determined with the live probe or by the »leanmeter".

The $\mathrm{h}^{2}$-estimates of the above investigations are given in Table 5 . The estimates are not completely comparable because the number of animals and the environmental conditions considerably influence the results. Similarly, the number of farms at which the progeny have been reared, and the relationships between the animals in particular have affected the $\mathrm{h}^{2}$-estimates (LAUPRECHT et al. 1967, Mennerich 1967, Rittler 1964, 1968 b, Vockert 1969). Systematic differences between farms are confounded with the differences between boars, and increase the $\mathrm{h}^{2}$-estimates considerably. There is a pronounced tendency towards over-estimation when the progeny are on one or two farms only (Mennerich 1967, Vockert 1969). Despite differences in conditions and populations, the $\mathrm{h}^{2}$-estimates for thickness of fat reported by most investigators are comparable. The average fat thickness of several measurements, has a greater heritability than that of individual measurements (MENNERICH 1967, 
Table 5. Heritability estimates of carcass characteristics determined by performance tests.

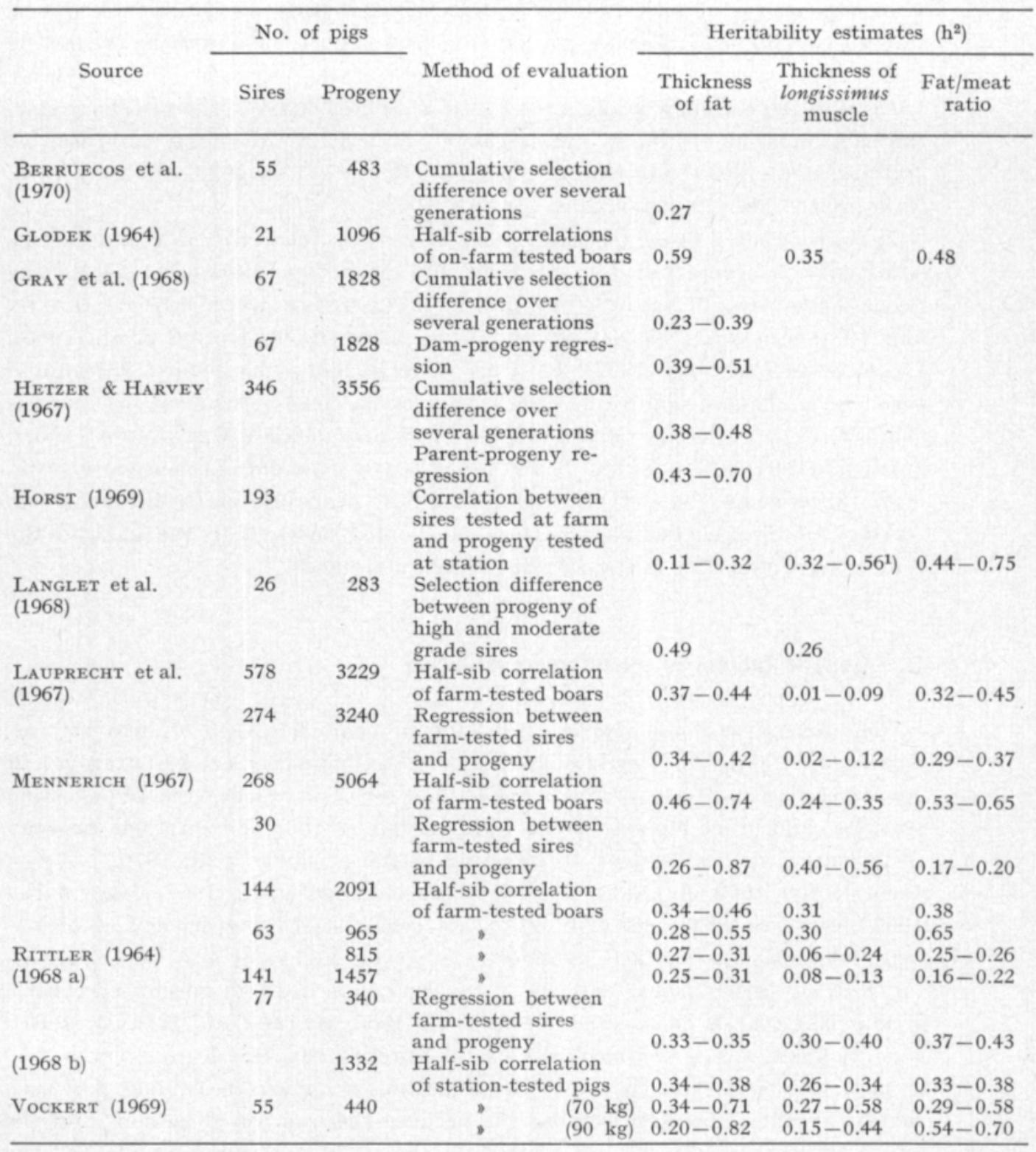

1) Figures for muscle area. 
Rittler 1968 b, Vockert 1969). Hetzer and HARwey (1967), in their selection experiment stretching over 8-10 generations, got higher $\mathrm{h}^{2}$-estimates for the fat thickness of the first generation and the low fat strains than for the last generation and the high fat strains.

In a number of investigations the $\mathrm{h}^{2}$-estimates for the ultrasonically measured cross-sectional area of the longissimus muscle were lower than those for the ultrasonically measured fat thickness (LAUPRECHT et al. 1967, RITTLER 1964, 1968 a) (Table 5). Using an improved ultrasonographic method, however, Horst (1969) obtained higher $\mathrm{h}^{2}$-estimates for the muscle area than for the thickness of the fat. The $\mathrm{h}^{2}$-estimates for the fat:meat ratio have usually been similar to those for the thickness of the fat (Table 5).

By comparing heritabilities of characteristics measured ultrasonically on live animals with the corresponding ones of the carcasses the reliability of the ultrasonic measurements can be determined. RITTLER (1968 b) obtained similar heritabilities for ultrasonic and carcass measurements of pigs reared at a testing station. Generally speaking, the $\mathrm{h}^{2}$-estimates for carcass-measured fat thickness in pigs reared at experimental stations has varied from 0.15 to 0.73 (more frequently $0.30-0.55)$, for longissimus muscle area from 0.09 to 0.56 , and for the fat:meat ratio from 0.28 to 0.72 (BIEDERMAnN 1971, ENFIELd and WhatLEY 1961, Flock 1970, FredeEn and Jonsson 1957, Jensen et al. 1967, JoHansson and Korkmann 1950, Jonsson 1971 a, KANgASNiemi 1971 b, LAngholz 1966, Maijala and Vainikainen 1962, Schmitten 1967, Siers and Thomsom 1972, VAro and Partanen 1965, Weiss 1967). The $\mathrm{h}^{2}$-estimates for growth rate in these studies were $0.14-0.67$ and those for feed efficiency 0.12 0.72 . The $\mathrm{h}^{2}$-estimates for growth rate in phenotype evaluation studies have been $0.03-0.46$ and those for feed efficiency 0.14-0.39 (Buchenauer 1970, Gerlach 1967, Mennerich 1967, Scholz 1965). Norwegian h²-estimates for combined fat + growth scores were $0.55-0.63$ (SKJERVOLD 1962).

In boar (testing station) - progeny studies it has not been possible, on account of the limited amount of data, to calculate heritabilities, but FEwSON et al. (1962) observed that the difference between progeny of thin-fat and thick-fat boars was according to expectation, and Minkema et al. (1964), in the station-testing of boars, got almost twice as reliable results as those obtained in full sib testing. In a preliminary report PERSSON and LINDHÉ (1972) give the following correlations between results of station tested boars and their progeny (at $90 \mathrm{~kg}$ ): fat thickness measured at several points and in material from several years $r=0.13-0.76$, growth rate $r=0.24-0.52$ and feed efficiency $r=0.40$. The correlations between the results of boars tested in the field and their progeny tested at stations were: fat thickness $r=0.11-0.61$, longissimus muscle area -0.27 to -0.48 and fat:meat ratio $0.23-0.72$ (FLOCK et al. 1970, Glodek 1964, Mennerich 1967). No statistically significant correlations between rate of growth for sires and progeny have been found (FLOCK 1970, MenNerich 1967).

Genetic correlations between fat thickness and longissimus muscle thickness (both measured ultrasonically), and between these and the fat:meat ratio, are given in Table 6. The table also shows the corresponding correlation coefficients for carcass characteristics of progeny-tested animals. The correlations 
for ultrasonic and carcass measurements are of about the same order. Fat thickness measured ultrasonically is more closely correlated with the fat:meat ratio than the ultrasonic measurements of the longissimus muscle. However,

Table 6. Genetic coefficients of correlation $\left(\mathrm{r}_{\mathrm{g}}\right)$ between thickness of fat and longissimus muscle, determined by ultrasonics, and measurement of carcass section and carcass characteristics determined by lean cut analysis.

\begin{tabular}{|c|c|c|c|}
\hline \multirow[b]{2}{*}{ Source } & \multirow[b]{2}{*}{ Ultrasonic measurement of live pig } & \multicolumn{2}{|c|}{ Carcass characteristics } \\
\hline & & $\begin{array}{l}\text { Longissimus } \\
\text { muscle thickness } \\
\qquad \mathrm{r}_{\mathrm{g}}\end{array}$ & $\begin{array}{c}\text { Fat/meat } \\
\text { ratio } \\
r_{\mathrm{g}}\end{array}$ \\
\hline GERLACH (1967) & Thickness of fat, 5 points & & 1.04 \\
\hline $\begin{array}{l}\text { LAUPRECHT et al. } \\
\text { (1967) }\end{array}$ & $\Rightarrow, \quad, 3$ & -0.45 & 0.99 \\
\hline MENNERich (1967) & $\begin{array}{l}\text { Thickness of fat towards side from } \\
\text { midback, } 3 \text { points }\end{array}$ & -0.48 & 0.93 \\
\hline RITTLER (1964) & Thickness of fat along side, 5 points & -0.40 & 0.96 \\
\hline$-(1968 \mathrm{a})$ & $\Rightarrow \quad, \quad 5$, & -0.04 & 0.95 \\
\hline $\begin{array}{l}\text { WENIGER et al. } \\
\text { (1967) }\end{array}$ & $\rightarrow, \quad, \quad$, & -0.07 & 0.96 \\
\hline $\begin{array}{l}\text { LAUPRECHT et al. } \\
\text { (1967) }\end{array}$ & $\begin{array}{l}\text { Thickness of longissimus muscle, } \\
3 \text { points }\end{array}$ & & -0.60 \\
\hline Mennerich (1967) & $\begin{array}{l}\text { Thickness of longissimus muscle } \\
\text { towards side from midback, } 3 \text { points }\end{array}$ & & -0.75 \\
\hline RitTLER (1964) & $\begin{array}{l}\text { Thickness of longissimus muscle } \\
\text { along side, } 5 \text { points }\end{array}$ & & -0.71 \\
\hline$-(1968 \mathrm{a})$ & $\begin{array}{l}\text { Thickness of longissimus muscle } \\
\text { along side, } 5 \text { points }\end{array}$ & & -0.27 \\
\hline $\begin{array}{l}\text { WENIGER et al. } \\
(1967)\end{array}$ & $\begin{array}{l}\text { Thickness of longissimus muscle } \\
\text { along side, } 3 \text { points }\end{array}$ & & -0.31 \\
\hline & Carcass section measurement & & \\
\hline KrIPPL et al. (1965) & Thickness of fat & -0.41 & \\
\hline BIEDERMANN (1971) & . & -0.44 to -0.50 & $0.64-0.80$ \\
\hline FLOCK (1970) & - & -0.34 & 0.73 \\
\hline JENSEN et al. (1967) & - & -0.06 & \\
\hline BIEDERMANN (1971) & Area of longissimus muscle & & -0.78 \\
\hline FLOCK (1970) & 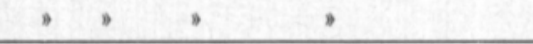 & & -0.82 \\
\hline
\end{tabular}

the cross-sectional area of the longissimus muscle as measured on the carcass is correlated with the fat:meat ratio as closely as is fat thickness. JENSEN et al. (1967), Rittler (1968 a) and Weniger et al. (1967) found no genetic correlation between fat thickness and the measurements of the longissimus muscle. The genetic correlations between growth and feed-utilisation characteristics and between these and carcass characteristics have already been given (page 31).

From a breeding point of view the genetic correlation of the ultrasonically 
measured fat and longissimus muscle with the lean cuts results gives the best indication of the value of ultrasonic measurements. There are few such studies. The genetic correlation coefficients $r_{g}$ obtained by RITTLER (1968 b) are as follows:

Thickness of fat

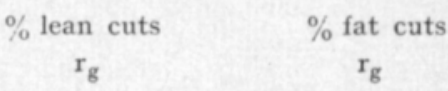

Thickness of longissimus muscle

measured ultrasonically on live animal ............. 0.55 to $0.57 \quad-0.26$ to -0.32

measured on carcass

$0.61-0.45$

Fat: meat ratio

measured ultrasonically on live animal

-0.81 to -0.90

0.62 to

measured on carcass

$-0.84$

Rittler's figures are comparable to those of JENSEN et al. (1967): $r_{\mathrm{g}}=-\mathbf{0 . 8 1}$ for fat thickness (carcass) vs lean cuts, and $r_{g}=0.49$ for longissimus muscle area (carcass) vs lean cuts. Thus, according to the results of Rittler, ultrasonic measurement of the live pig is as reliable as carcass measurement in breeding for meatiness. 


\section{Author's studies}

\section{A. Material and methods}

\section{Test boars and their rearing}

Housing for 30 boars was put up in the vicinity of the Pig Husbandry Experiment Station of North Finland (Haapajärvi 01). Group A was reared in 1967 and Group B in $1968-69$, making a total of 60 boars.

In order to speed up progeny evaluation, one half of the boars selected were of Yorkshire and one half of Landrace breed.

$2-3$ boar piglets were selected from each of 24 litters in various parts of Finland. Their sires (19 in all) and dams were of the highest quality available. From the very best sires piglets were taken from several litters. In making the selection the aim was to follow a procedure corresponding to a situation where animals were selected for the only boar testing station in the country.

The 30 boar piglets of Group A were brought to the testing station over the shortest possible period, so that they could be reared and evaluated at the same time. The piglets were born between June 2nd and July 24th 1967. After rearing, the boars were retained for varying periods while semen was being collected from them. When a place became vacant it was filled with a Group B piglet. The piglets of Group B were born between January 27th and October 25 th 1968 .

Individual feeding of the boars, 2 or 3 of which were housed in each pen, was arranged by lowering partitions at feeding time. Each boar was fed twice daily with a restricted amount of feed depending on its weight (Table 7). Restricted feeding was employed in order to avoid leg weakness. The level of feeding for Group A was generally the same as that used for test boars in Finland (EtTala 1971 a). In Group B, the amount of feed proved to be too restricted during the first weeks and was increased by 0.1 feed units per day until the animals weighed $60 \mathrm{~kg}$, after which the amounts followed the 1967 standard up to a liveweight of $80 \mathrm{~kg}$, and were then 0.1 feed units less than the 1967 standard. The composition of the feed was uniform throughout, being the same as that used for all progeny, up to a weight of $50 \mathrm{~kg}$, tested for breeding purposes in Finland (Table 8). The animals were given water ad libitum, and the boars were weighed once a week. 
Table 7. Feeding standards for the boars. $\mathrm{FU}=$ Scandinavian feed unit.

\begin{tabular}{|c|c|c|c|c|}
\hline \multirow{2}{*}{\multicolumn{2}{|c|}{$\begin{array}{l}\text { Live weight of boar } \\
\qquad \mathrm{kg}\end{array}$}} & \multicolumn{3}{|c|}{ FU/boar/day } \\
\hline & & 1967 & (Group A) & $1968-69$ (Group B) \\
\hline $20.0-24.9$ & ........ & & 0.8 & 0.9 \\
\hline $25.0-29.9$ & …………… & & 1.0 & 1.1 \\
\hline $30.0-34.9$ & ................... & & 1.2 & 1.3 \\
\hline $35.0-39.9$ & ................... & & 1.4 & 1.5 \\
\hline $40.0-44.9$ & n.................. & & 1.6 & 1.7 \\
\hline $45.0-49.9$ & ................... & & 1.8 & 1.9 \\
\hline $50.0-54.9$ & .................... & & 1.9 & 2.1 \\
\hline $55.0-59.9$ & (................... & & 2.1 & 2.2 \\
\hline $60.0-69.9$ & .................... & & 2.3 & 2.3 \\
\hline $70.0-79.9$ & …………… & & 2.6 & 2.6 \\
\hline $80.0-89.9$ & …………… & & 2.9 & 2.8 \\
\hline $90.0-$ & n.t................ & & 3.1 & 3.0 \\
\hline
\end{tabular}

Table 8. Composition of feed of test boars and 1968 progeny.

\begin{tabular}{|c|c|c|}
\hline Composition of feed & $\begin{array}{c}\text { Group A } \\
\text { Aug.-Oct. } 1967 \\
\%\end{array}$ & $\begin{array}{c}\text { Group B } \\
1968-69 \\
\%\end{array}$ \\
\hline Barley meal ... & 52.0 & 52.0 \\
\hline Maize meal ....... & 26.0 & 28.5 \\
\hline Dried milk .................. & 10.0 & 0.0 \\
\hline Fish meal ...................... & 4.5 & 12.0 \\
\hline Soyabean meal ............... & 3.0 & 3.0 \\
\hline Yeast .......................... & 2.0 & 2.0 \\
\hline Mineral mixture $^{1}$ ) ............. & 2.0 & 2.0 \\
\hline Vitamin preparation $\left.{ }^{2}\right) . . . .$. & 0.5 & 0.5 \\
\hline Energy values $\mathrm{FU} / \mathrm{kg}^{3}$ ) $\ldots$. & 1.01 & $0.97-1.00$ \\
\hline True protein $\%^{3}$ ) ............. & 15.2 & $16.3-19.3$ \\
\hline
\end{tabular}

1) Composition of mineral mixture, \%: fodder phosphate 40.0, ground limestone 40.0, common salt 18.5 , zinc sulphate 0.75 , iron sulphate 0.60 , copper sulphate 0.065 , manganese sulphate 0.10 , cobalt sulphate 0.01 and potassium iodide 0.005 .

${ }^{2}$ ) Composition of vitamin preparation: vitamin A 600000 i.u., vitamin D 60000 i.u. and vitamin E $2000 \mathrm{mg}$ per $\mathrm{kg}$ feed.

${ }^{3}$ ) Analysis done at the State Institute of Agricultural Chemistry, on each batch of feed. $\mathrm{FU}_{\mathrm{L}}=$ Scandinavian feed unit.

\section{Evaluation, selection and use in breeding of test boars}

In the phenotype evaluation of the boars, rate of growth, feed efficiency, thickness of fat, length of side and leg condition, as well as the ham measurement of the boars in Group B, were determined.

Growth and feed efficiency were calculated for the weight range $20-88 \mathrm{~kg}$. If the initial and final weights diverged from these, correction coefficients, uniform with those employed in progeny testing, were used. The coefficients per $\mathrm{kg}$ liveweight were 2.58 days and 2.30 feed units at the beginning of the test, 
and 1.25 days and 4.19 feed units at the end of the test. Another growth characteristic used was the age in days at a weight of $88 \mathrm{~kg}$. When the boars were selected for progeny testing the characteristic used was the number of growth points determined by using weight-age nomograms (Figs. 3 and 5) prepared by SUNDGREN $(1965,1967)$.

Ultrasonic measurement of the fat thickness of the boars was done by staff of the Finnish Pig Breeding Society. The measurement was made as near as possible to a live weight of $\mathbf{8 8} \mathrm{kg}$, the long jorneys involved preventing complete uniformity in this respect. The equipment used was the Krautkrämer USM 1 or USK $5 \mathrm{SF}$. Measuring was done at points along the midline of the back at the withers (1), midback (2) and loin (3) (Fig. 1). The thickness of the side fat, that is the so-called sol fat, was measured at a point $8 \mathrm{~cm}$ from the midline of the back on both sides, at the rear edge of the last rib (4 and 5). The side length was measured from the rear edge of the front leg to the base of the tail (Fig. 1). The ham measurement (Group B only) was made as shown in Fig 2 (UUsisalmi $1971 \mathrm{c}$ ). The legs were evaluated as follows:

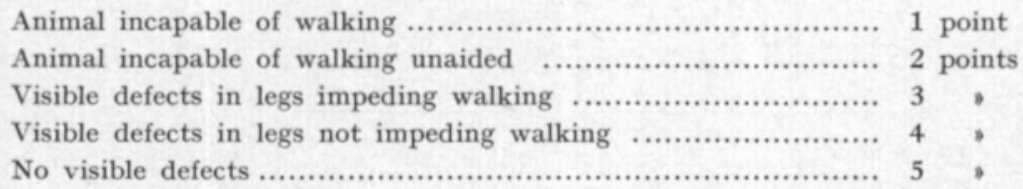

The uncorrected fat thickness average $(1,2,3)$ for the withers, midback and loin, representing average back fat, was converted to fat points by means of the scale shown in Fig. 4. The uncorrected average $(2,4,5)$ for the midback and the two sol measurements was converted to fat points by means of the scale shown in Fig. 6. The points scales are the same as those prepared by SUNDGREN $(1965,1967)$, except that instead of the above-mentioned averages Sundgren used sol fat measurements. Test points were obtained by summing growth and fat points. The old test point scales (Figs. 3 and 4) were official in Finland until October 15th 1968, when new point scales were introduced. Consequently, the selection of the boars of Group A for progeny evaluation was based on the old points scales, and that for Group B on the new scales. Test points (old system) and test points (new system) were calculated for all boars.

The intention was to select for progeny evaluation the 5 best, 5 average and the 5 poorest boars, in terms of test points, from each of the two groups of 30 boars. Surplus candidates for each sub-group were eliminated when necessary on the basis of their breed, since it was desired to strive for an overall balance between the two breeds. The selection could not be made entirely as intended because some boars had to be rejected on account of leg defects. Later, other boars had to be eliminated because of low semen quality or difficulties in obtaining the ejaculate, and also because of subsequent leg defects and injuries. In Group A there were insufficient reserve boars, so that for progeny evaluation the sub-groups were limited to 3 good, 4 average and 4 poor boars. A large number of Group B boars were held in reserve, so that the sub-groups of Group B could be brought up to number $\mathbf{5}+\mathbf{5}+\mathbf{5}$ as intended. The quality 


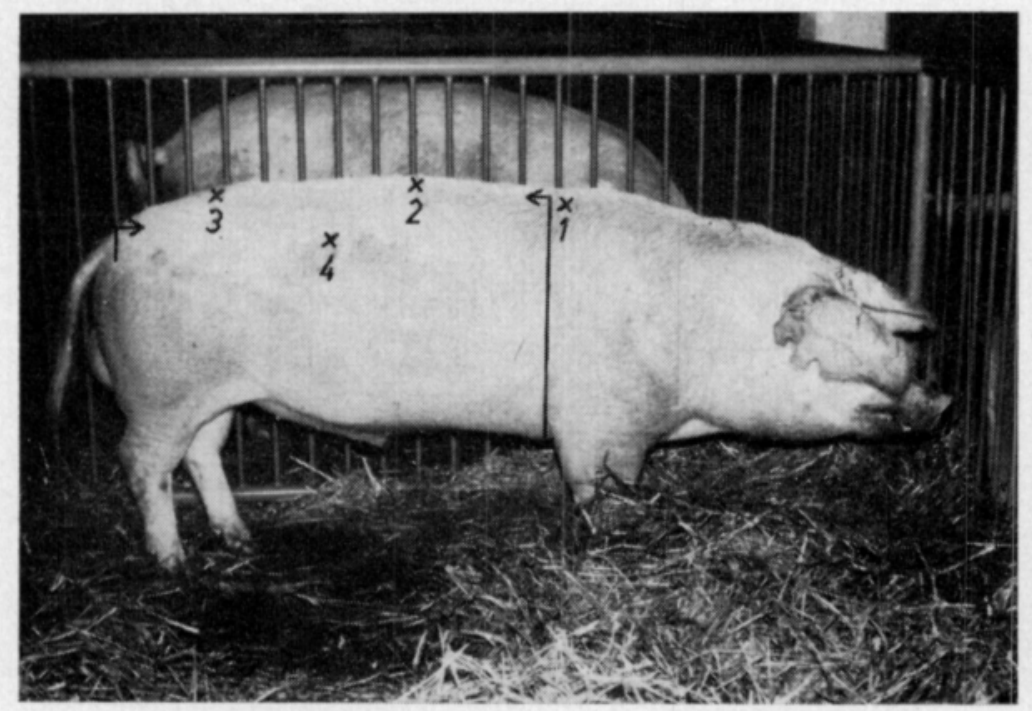

Fig. 1. Locations of ultrasonic measurements of fat on test boars, and manner in which length of side was measured. (Boar "Rukkis, see Table 14).

$1=$ withers, behind shoulder blades

$2=$ midback, thinnest place

$3=$ loin, thinnest place

$4=$ sol fat, right side, at rear edge of last rib, about $8 \mathrm{~cm}$ from midline of back (on pig weighing about $88 \mathrm{~kg}$ ).

Side length is the distance between the vertical lines.

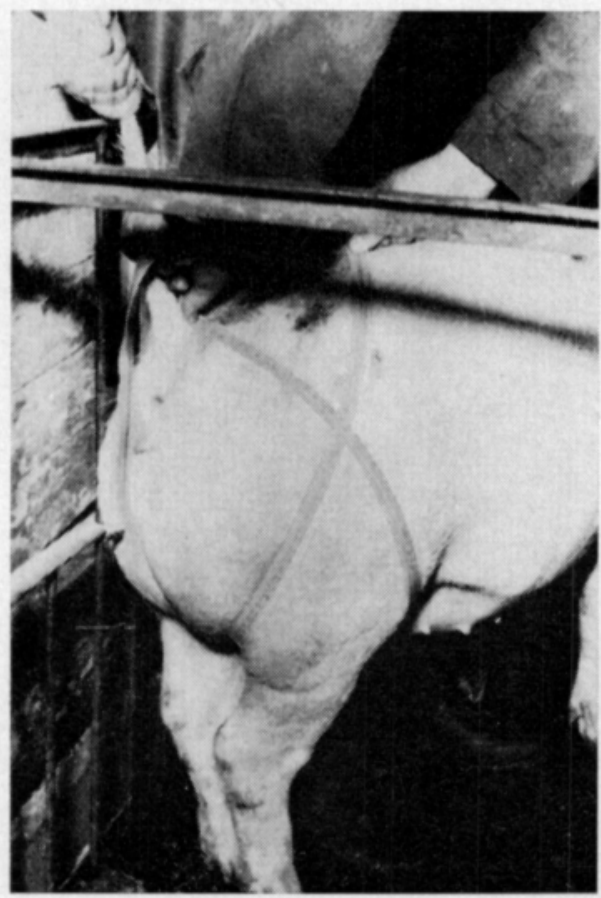

Fig. 2. Method of measuring the ham. (Photo U. Uusisalmi 


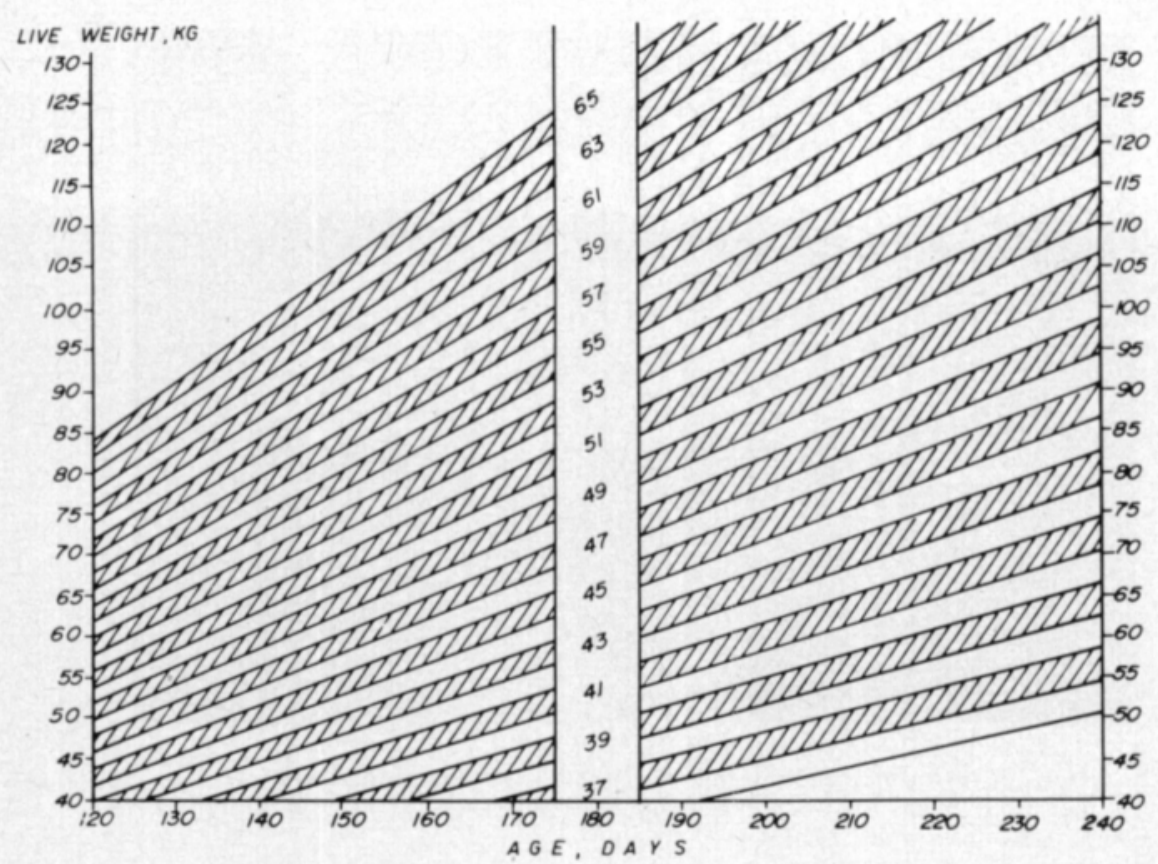

Fig. 3. Assessment of Group A (1967) boars: weight-age nomogram giving growth points (old system).

BACK FAT THICKNESS, MM

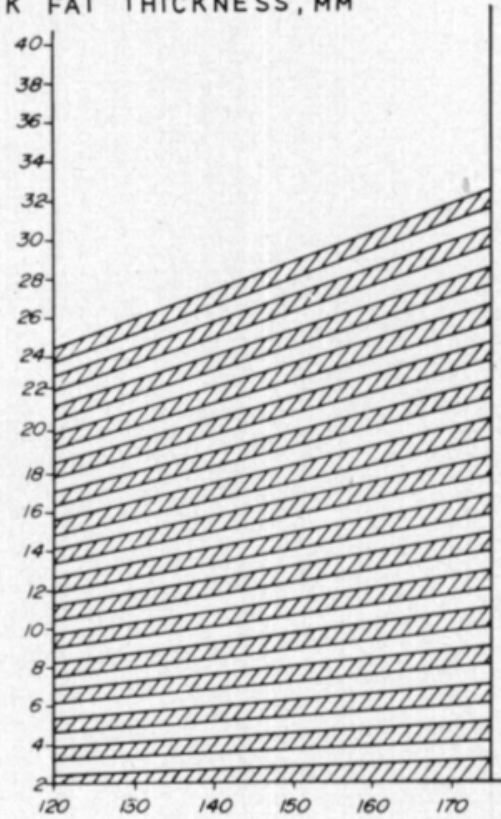

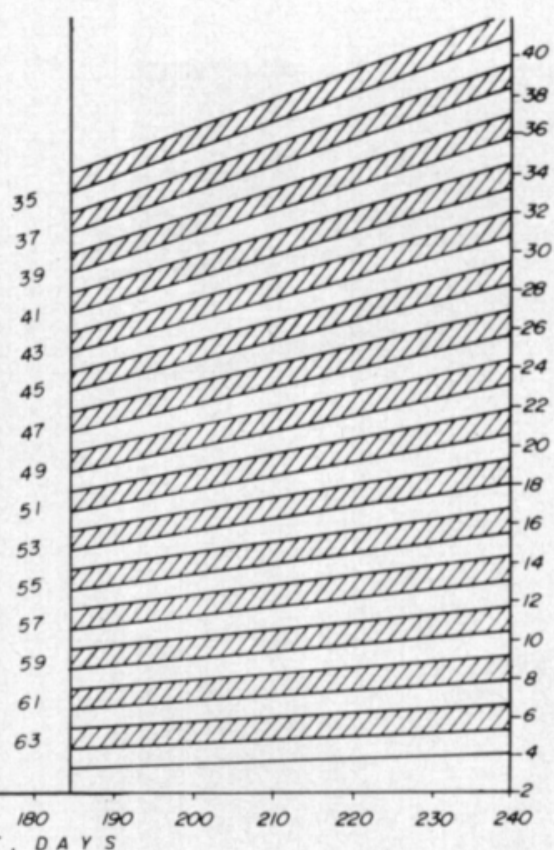

Fig. 4. Assessment of Group A (1967) boars: fat thickness-age nomogram giving fat points (old system). Back fat thickness is the mean of the fat thickness at withers, midback and loin. 


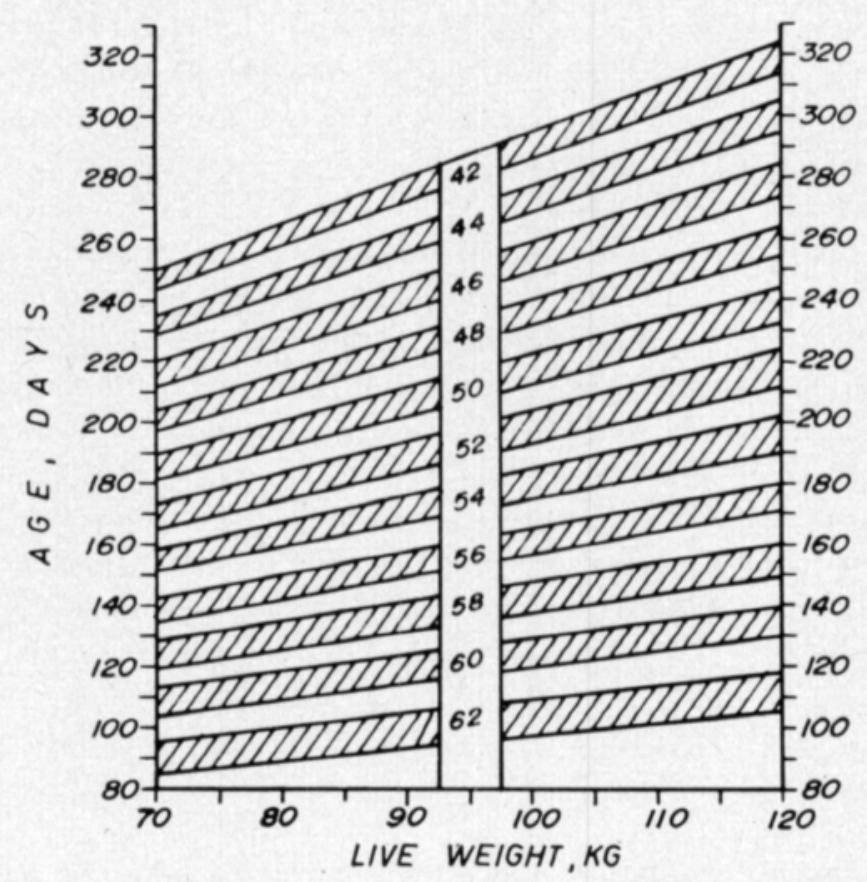

Fig. 5. Assessment of Group B (1968/69) boars: age-weight nomogram giving growth points (new system).

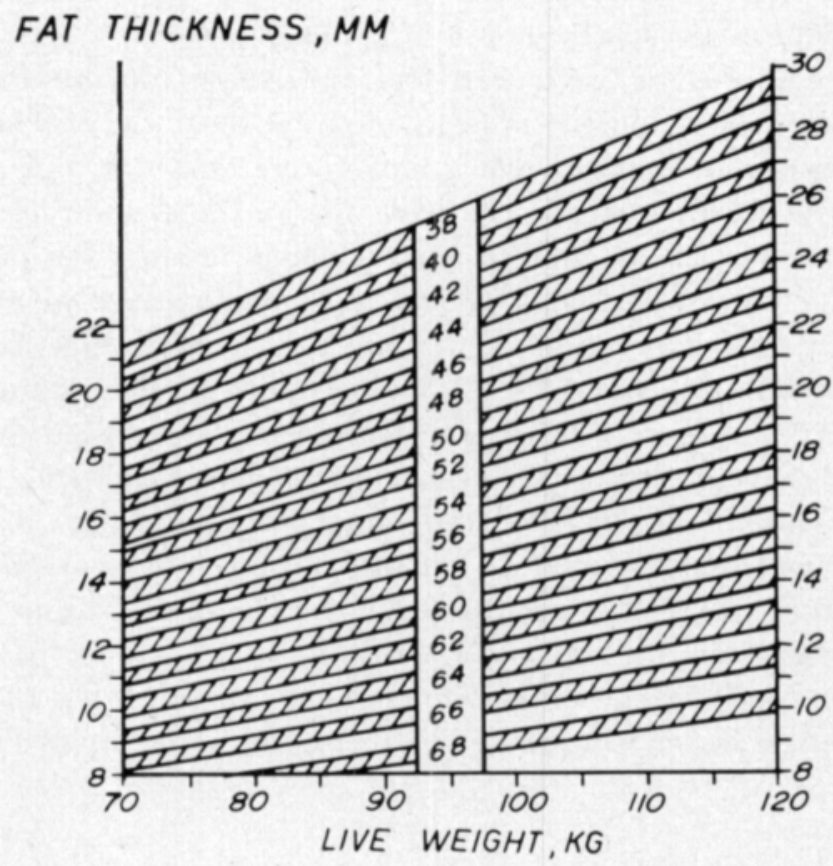

Fig. 6. Assessment of Group B (1968/69) boars: fat thickness-weight nomogram giving fat points (new system). Fat thickness is the mean of the thickness of the sol fat (right side plus left side) and the midback fat. 
of the reserve boars was only slightly above or slightly below average, for boars of average grade were in the majority. The introduction of reserve boars naturally reduced the differences between the sub-groups. A further weakness is that the selection of the Group B boars was made over a period of time, i.e. several months.

When the boars of Group A attained breeding age, a boar station, subordinate to the North Finland Artificial Insemination Society, was established at the testing station. Inseminations were done within a region of approximately 100 $\mathrm{km}$ radius. In most of this area sows had not been artificially inseminated previously, and initially the demand for semen was low. The semen was used chiefly at small piggeries. Three of the test boars were housed at neighbouring farms in order to make room for other boars. When the Group B boars selected for progeny evaluation reached breeding age they were transported to the boar station of the Salpausselkä AI Society. Here, in the Lahti area, AI of pigs was already widespread.

\section{Progeny and their rearing}

For the progeny evaluation, the intention was to take one barrow piglet from each of 16 litters sired by Group A boars, and one boar and one barrow from each of 10 litters sired by the Group B boars. As AI was used the progeny were randomly distributed to all parts of the two districts, except for the progeny of the three Group A boars mentioned above, which came from 3-6 farms only. Also in these cases matings to closely related sows were avoided. The piglet or piglets from each litter were randomly picked.

The Group A progeny were reared at the North Finland Pig Husbandry Experimental Station, and the progeny of Group B at the Hyvinkää Pig Husbandry Experimental Station. The animals were housed 4 to a pen, and were group fed. The pigs in any one pen were always the progeny of a single boar; their ages and starting dates were not the same, because the pigs came from $2-4$ litters. The feed portions were based on the average weight of the pigs in the pen, got by weekly weighing. Amounts and composition of feed are given in Tables 8 (1968-69), 9 and 10. At the beginning of 1969, during the rearing of the progeny of Group A boars, the feeding levels and feed quality used in Finland were changed, the former being raised for liveweights up to $65 \mathrm{~kg}$. The increase amounted to $0.05-0.4$ feed units per animal per day, after which the feeding level approximated to appetite. The feed mixture for the progeny in 1968 was the same as that for the test boars (Table 8). From the beginning of 1969 onward, each pig was given, separately, $150 \mathrm{~g}$ milk powder per day, the rest of the feed being composed mainly of cereals (Table 10). This revised feeding was used throughout the test of progeny of Group B boars. 
Table 9. Feeding standards for progeny of test boars.

\begin{tabular}{|c|c|c|c|c|c|}
\hline \multicolumn{3}{|c|}{1968 (Group A) } & \multicolumn{3}{|c|}{ 1969-71 (Group B) } \\
\hline \multicolumn{2}{|c|}{$\begin{array}{l}\text { Weight of pig } \\
\text { kg }\end{array}$} & FU/pig/day & \multicolumn{2}{|c|}{$\begin{array}{c}\text { Weight of pig } \\
\text { kg }\end{array}$} & \multirow{2}{*}{$\begin{array}{c}\text { FU/pig/day } \\
1.20\end{array}$} \\
\hline $20.0-24.9$ & & 0.90 & $20.0-22.4$ & & \\
\hline $25.0-29.9 \ldots$ & …...................... & 1.10 & $22.5-24.9$ & c...................... & 1.30 \\
\hline $30.0-34.9 \ldots$ & …..................... & 1.30 & $25.0-27.4$ & …...................... & 1.40 \\
\hline $35.0-39.9 \ldots$ & …...................... & 1.60 & $27.5-29.9$ & n....................... & 1.50 \\
\hline $40.0-44.9$ & ……………… & 1.80 & $30.0-32.4$ & 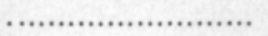 & 1.60 \\
\hline $45.0-49.9 \ldots$ & ………………… & 2.10 & $32.5-34.9$ & 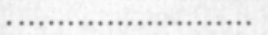 & 1.70 \\
\hline $50.0-54.9 \ldots$ & 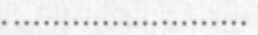 & 2.25 & $35.0-37.4$ & …..................... & 1.80 \\
\hline $55.0-59.9 \ldots$ & ………............. & 2.45 & $37.5-39.9$ & 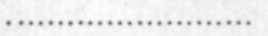 & 1.90 \\
\hline $60.0-64.9$. & ………………… & 2.65 & $40.0-42.4$ & 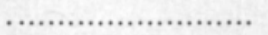 & 2.00 \\
\hline $65.0-69.9$. & …..................... & 2.80 & $42.5-44.9$ & 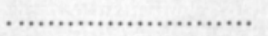 & 2.10 \\
\hline $70.0-74.9$. & ………............. & 2.90 & $45.0-47.4$ & 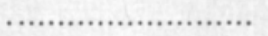 & 2.20 \\
\hline $75.0-79.9 \ldots$ & ………………… & 3.00 & $47.5-49.9$ & 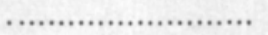 & 2.30 \\
\hline $80.0-84.9$ & ….................... & 3.10 & $50.0-54.9$ & 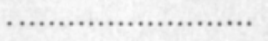 & 2.40 \\
\hline \multirow[t]{7}{*}{$85.0-\quad}$. & (n...................... & 3.20 & $55.0-59.9$ & 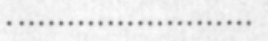 & 2.60 \\
\hline & & & $60.0-64.9$ & 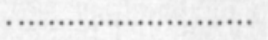 & 2.70 \\
\hline & & & $65.0-69.9$ & ……………… & 2.80 \\
\hline & & & $70.0-74.9$ & …….................. & 2.90 \\
\hline & & & $75.0-79.9$ & 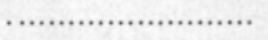 & 3.00 \\
\hline & & & $80.0-84.9$ & 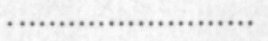 & 3.10 \\
\hline & & & $85.0-$ & 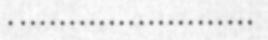 & 3.20 \\
\hline
\end{tabular}

Table 10. Composition of feed of boar progeny 1969-71.

\begin{tabular}{|c|c|}
\hline Barley meal. & $90.0 \%$ \\
\hline Fish meal ..................................... & $8.0 \%$ \\
\hline Mineral mixture $\left.{ }^{1}\right)$ & $1.5 \%$ \\
\hline Vitamin preparation $\left.^{2}\right) \quad \ldots \ldots \ldots \ldots \ldots \ldots$ & $0.5 \%$ \\
\hline
\end{tabular}

1) Composition of mineral mixture, \%: fodder phosphate 38.0, ground limestone 38.8, common salt 20.0 , zinc oxide 0.65 , iron sulphate 0.85 , copper sulphate, manganese sulphate 0.85 , cobalt sulphate 0.033 and potassium iodide 0.007 .

2) Composition of vitamin preparation: A 800000 i.u., $D_{3} 160000$ i.u., E $4000 \mathrm{mg}$, riboflavin $800 \mathrm{mg}$, D-pantothenic acid $3000 \mathrm{mg}$, niacin $5000 \mathrm{mg}$, vitamin $\mathrm{B}_{12} 4 \mathrm{mg}$ per $\mathrm{kg}$ feed.

\section{Progeny evaluation}

The rate of growth and average feed efficiency of all progeny were determined, and carcass characteristics were evaluated by measurements on the carcass section and lean cuts analysis. Additional measurements were taken for the Group B progeny, i.e. ultrasonic measurement of fat thickness, ham measurement, and leg assessment.

The rate of growth of the progeny, as with the boars, was expressed in terms of (i) daily growth between 20 and $88 \mathrm{~kg}$ liveweight and (ii) age at the weight of $88 \mathrm{~kg}$. Variation in initial and final weight was corrected for by interpolation, with the aid of a computer. Determination of age at weight intervals of $10 \mathrm{~kg}$ was also done by interpolation. Feed efficiency averages per pen and per boar 


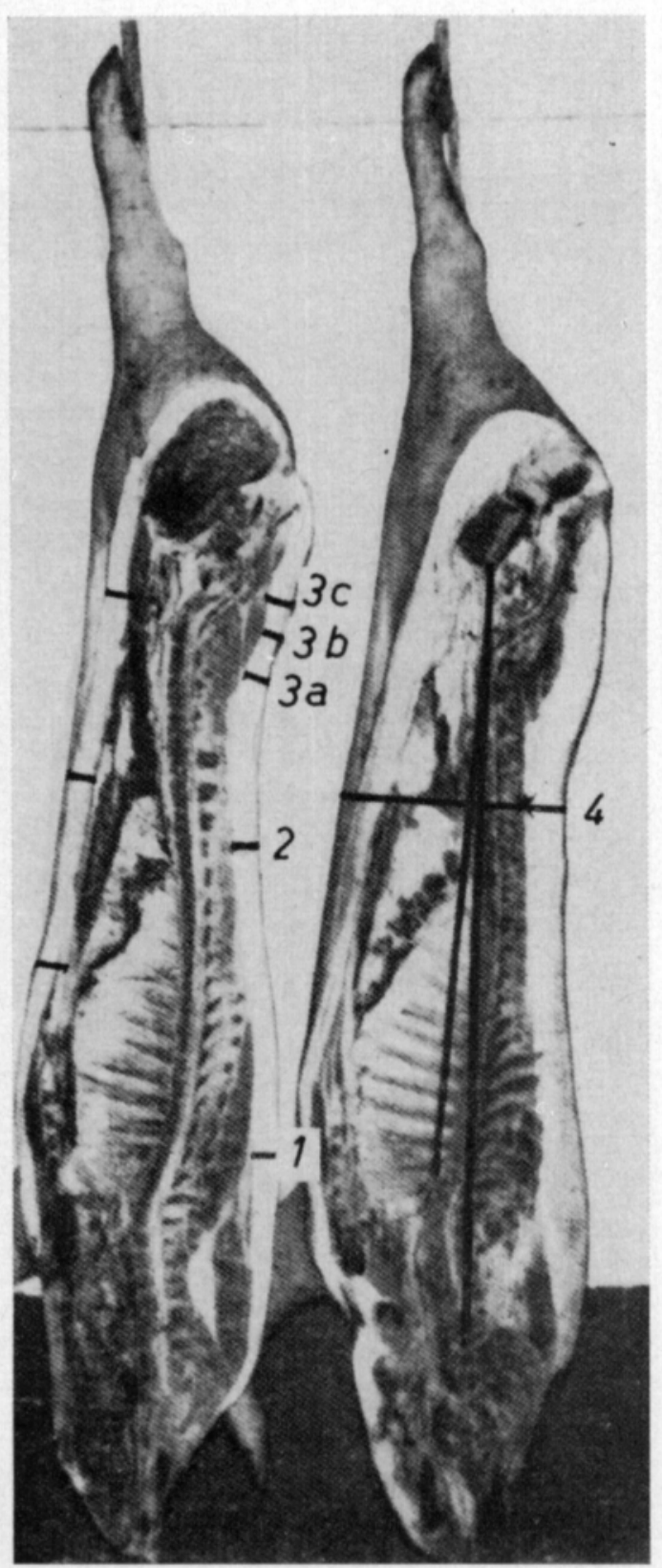

Fig. 7. Positions for fat thickness measurement of porcine carcass section (PARTANEN 1965). $1=$ withers, $2=$ midback, $3 \mathrm{a}=$ fore loin, $3 \mathrm{~b}=$ mid loin (corresponding to loin fat measured ultrasonically), $3 \mathrm{c}=$ rear loin, $4=$ side fat. The longissimus muscle is measured along the horizontal line shown, and the side length is the length of the short vertical line.

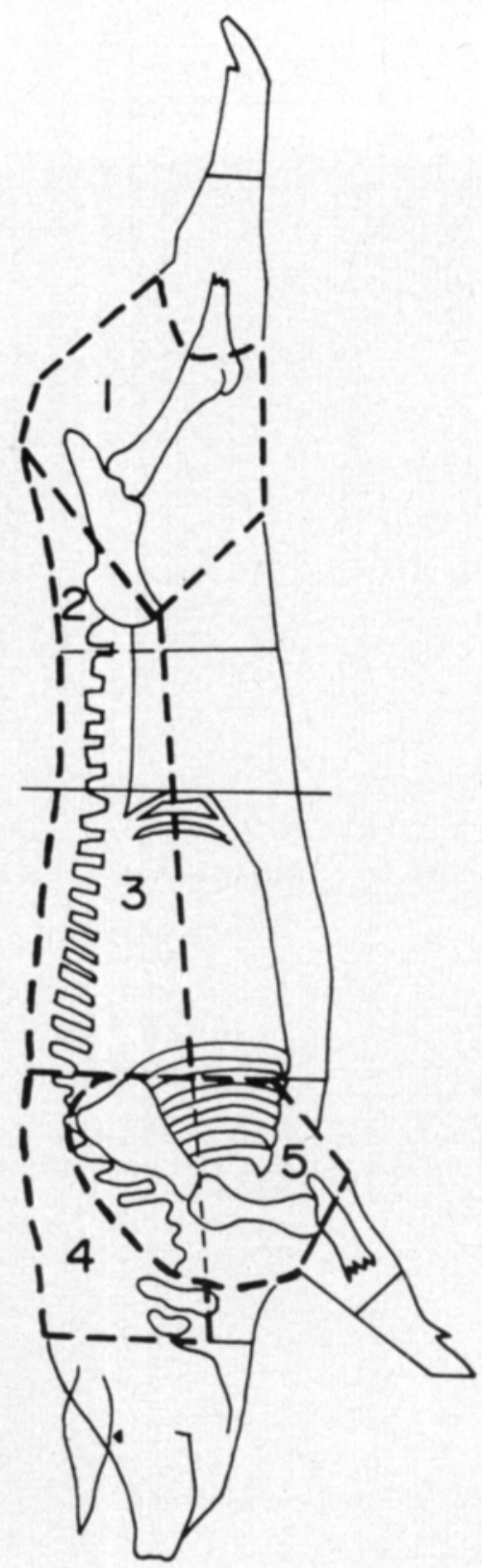

Fig. 8. Porcine carcass, showing the most important parts (UUSISALMI 1969a).

$1=$ ham, $2=$ loin, $3=$ back, $4=$ foreback, $5=$ shoulder. 
were calculated for the liveweight interval 20 to $88 \mathrm{~kg}$. Variation in initial and final weight was corrected for, as with the test boars, by means of the factors 2.30 and 4.19 feed units per kg liveweight. Carcass section measurements and lean cuts analysis were made by ordinary methods (Fig. 7, PARTANEN 1965; Fig. 8, Uusisalmi 1969 a).

The ultrasonic measurements of fat thickness were made with Krautkrämer USK 4 apparatus at the same loxations as for the test boars (Fig. 1). The measurements were made twice, $\mathbf{8}$ weeks after the start of the test and just before slaughter, when the liveweight was close to $\mathbf{8 8} \mathrm{kg}$. Data obtained at the latter stage were converted to fat points, as had been done with the test boars by using the nomograms shown in Figs. 4 and 6 . Growth points were determined similarly (Figs. 3 and 5). Test points (growth + fat) according to the old system were obtained by summing the growth and fat points got from the nomograms in Figs. 3 and 4, and the test points according to the new system, correspondingly, by using the nomograms in Figs. 5 and 6. The ham measurements and leg assessments were made in the manner employed with the test boars (p. 40, Fig. 2). Detailed records of leg defects were kept.

\section{Statistical methods}

Statistical analyses were carried out at The Agricultural Research Centre using an IBM 1130 computer.

The effects of the linear regression - and class variables on the characteristics of the animals were tested by least squares analyses (HARVEY 1966, NENONEN 1972, SCHEFFE 1961). The regression variables were initial weight and age or final weight and age. The class variables were year, testing station, feeding level, castration, breed, group (A or B) and sire. Because variables often are interrelated, the proportion of the total variation accounted for by the model was also calculated. The general model (DrAPER and SMrth 1966, p. 128) was as follows:

$$
y=a_{0}+a_{1}+\ldots+a_{n}+b_{1} x_{1}+\ldots+b_{m} x_{m}+\underline{e},
$$

in which $\mathrm{y}=$ dependent variable, $\mathrm{a}_{0}=$ constant, $\mathrm{a}_{1} \ldots \mathrm{a}_{\mathrm{n}}=$ class variables, $\mathrm{b}_{1} \ldots \mathrm{b}_{\mathrm{m}}=$ regression coefficients, $\mathrm{x}_{1} \ldots \mathrm{x}_{\mathrm{m}}=$ regression variables, and $\underline{\mathrm{e}}=$ normally distributed random error with expected average of 0 .

The significance of the differences between means was determined by Tukey's test (SPEEL and TORRIE 1960). Certain effects of the variables were eliminated through the use of pooled estimates (NENONEN 1972): the sums of squares required for the calculation of the correlation matrix are calculated separately for each subclass average. By adding up the sums of squares within each class, estimates of the sums of squares, independent of the differences between the classes, are obtained (compare with "Analysis of variance" HALD 1952, p. 412). These sums of squares are divided by their degrees of freedom to give unbiassed estimates of the covariances, which can be used in stead of the original covariances. The effects of testing station, feeding and difference between boars and barrows on the various characterics were eliminated in this way. 
The interrelationships between characteristics were studied by means of correlation analysis, using both weight-corrected and uncorrected values. The corrections were made by eliminating the weight variable (NENONEN 1972). The correlations calculated from the corrected data are actually partial correlations. The models best describing the dependent variables were obtained by means of stepwise multiple regression analysis (DRAPER and SмIтH 1966, NENONEN 1971). The relative and absolute importance of each independent variable was also determined by the programme. The form of the expression was as follows:

$$
y=a_{0}+a_{1} x_{1}+a_{2} x_{2}+\ldots+a_{n} x_{n}+\underline{e},
$$

in which $\mathrm{y}=$ dependent variable, $\mathrm{a}_{0}=$ constant, $\mathrm{a}_{1} \ldots \mathrm{a}_{\mathrm{n}}=$ regression coefficients, $x_{1} \ldots x_{n}=$ dependent variables, and $\underline{e}=$ normally distributed random error with expected average of 0 .

Missing observations were automatically excluded from the analysis.

The heritability estimates of the characteristics were calculated both from sire-progeny regressions $\left(\mathrm{h}^{2}=2 \mathrm{~b}\right)$ and half $\mathrm{sib}$ correlations of the progeny, the regressions being calculated by means of the NenONEN (1971) programme described above.

Calculation of $\mathrm{h}^{2}$ from the half sib correlations was made by means of hierarchic variance analysis (SOKAL and RoHLF 1969) in accordance with a programme prepared by MrNG-PI Mr (1962). In analysing data for all progeny (Group A plus Group B), the average between-group sum of squares was calculated as the first level. Within Group B the average boar-barrow sum of squares was calculated, and within this the average sire sum of squares for the boar-progeny and barrow-progeny. It was not possible to obtain an average between-dam sum of squares, because in calculating the barrow- and boarprogeny separately there was only one piglet per litter. The heritability estimate in this case is given by

$$
\mathrm{h}^{2}=\frac{4 \sigma_{\mathrm{s}}^{2}}{\sigma_{\mathrm{s}}^{2}+\sigma_{\mathrm{e}}^{2}},
$$

where $\sigma_{\mathrm{s}}^{2}=$ between-sire variance component, and $\sigma_{\mathrm{e}}^{2}=$ error variance component.

The standard errors were calculated by means of the programme (MrNGPr Mr 1962), using the following relationship:

$$
\text { s.e. }\left(h^{2}\right)=\sqrt{\frac{32 h^{2}}{d f+1}},
$$

where s.e. $\left(\mathrm{h}^{2}\right)=$ standard error, $\mathrm{df}=$ degrees of freedom.

In order to determine the genetic correlations, both hierarchic variance analysis and hierarchic covariance analysis (MrNG-PI Mr 1962) were carried out. The genetic coefficient of correlation, $r_{g}$, is given by

$$
\mathrm{r}_{\mathrm{g}}=\frac{\sigma_{\mathrm{s} 12}}{\sqrt{\sigma_{\mathrm{s} 1}^{2} \sigma_{\mathrm{s} 2}^{2}}},
$$


where $\sigma_{\mathrm{s} 12}=$ between-sire covariance component for variables 1 plus 2 , $\sigma_{\mathrm{s} 1}^{2}=$ between-sire variance component, variable $1, \sigma_{\mathrm{s} 2}^{2}=$ between-sire variance component, variable 2 .

Estimates of the standard error of $r_{g}$ were calculated by means of the programme, using the following relationship:

$$
\text { s.e. }\left(r_{g}\right)=\left(1-r_{g}^{2}\right) \sqrt{\frac{\text { s.e. }\left(h_{1}^{2}\right) \text { s.e. }\left(h_{2}^{2}\right)}{2 h_{1}^{2} h_{2}^{2}}},
$$

where s.e. $\left(\mathrm{h}_{1}^{2}\right)$ and s.e. $\left(\mathrm{h}_{2}^{2}\right)$ represent the mean standard errors of the heritabilities for variables 1 and 2 .

\section{B. Results}

\section{Test boars}

a. Phenotype evaluation: results and factors affecting them

The averages for the various characteristics of the 60 test boars used in the study are given in Table 11. Generally, the testing was done at live weights close to the desired range $(21.6-87.9 \mathrm{~kg})$, though the range of single values was considerable: initial weight $17.0-28.4 \mathrm{~kg}$, weight at ultrasonic measurement $70-109 \mathrm{~kg}$. The initial age range was $51-87$ days, and that at ultrasonic measurement $143-214$ days.

The boars grew relatively slowly and had relatively thin layers of fat, the restricted feeding and the feed mixture employed evidently being the cause. The fat was thickest at the withers and thinnest at the midback. The fat points and standard deviations in the old system were smaller than those in the new system. The boars scored the same growth points, on average, according to both old and new scales. The standard deviation of the new-scale growth points (Fig. 5) was smaller than that of the old-scale growth points (Fig. 3).

8 of the boars $(13 \%)$ had to be withdrawn from the testing on account of weak legs; 5 of these were from two litters. Leg weakness occurred in both good and low-grade boars, rated according to test points. Of the 30 selected boars, 4 had to be excluded on account of poor semen quality or difficulty in obtaining semen.

I n itial weight had a significant effect on the age at $88 \mathrm{~kg}$, on the weight 8 weeks after the beginning of the test and on feed consumption per $\mathrm{kg}$ weight increase (Table 12). The boars starting the test at a relatively high initial weight had a lower feed efficiency than those starting at a smaller weight. The effect of initial weight on fat thickness was slight, the primary effect being on the age at $88 \mathrm{~kg}$. The early rate of growth of the piglet thus had a considerable influence on the rate of growth measured during the test.

An increase in the weight at ultrasonic measurement was associated with a highly significant increase in fat thickness (Table 12). It can be seen from the linear regression coefficients that an increase of one $\mathrm{kg}$ in the weight at ultrasonic measurement resulted in an increase in fat thickness 
Table 11. Characteristics of the 60 test boars used in the study (Group A + Group B).

\begin{tabular}{|c|c|c|}
\hline Characteristics & Average & $\begin{array}{l}\text { Standard } \\
\text { deviation }\end{array}$ \\
\hline Initial weight, $\mathrm{kg}$ & 21.6 & 2.8 \\
\hline 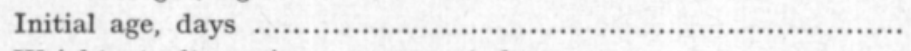 & 68.5 & 8.2 \\
\hline Weight at ultrasonic measurement, $\mathrm{kg}$ & 87.9 & 10.4 \\
\hline 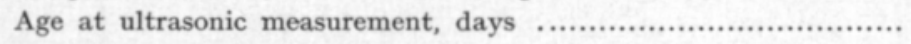 & 179.1 & 12.6 \\
\hline Weight after 8 weeks, $\mathrm{kg}$ & 48.7 & 5.2 \\
\hline 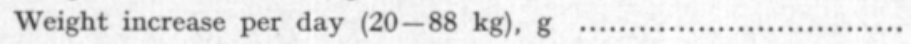 & 597.0 & 70.9 \\
\hline 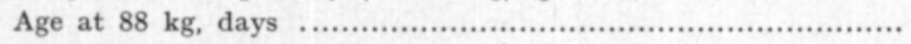 & 179.8 & 14.5 \\
\hline FU/kg weight increase $(20-88 \mathrm{~kg})$ & 2.87 & 0.4 \\
\hline Fat thickness, mm & & \\
\hline withers (1) ....... & 21.2 & 4.0 \\
\hline 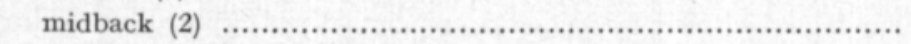 & 16.0 & 3.3 \\
\hline loin (3) & 17.5 & 3.6 \\
\hline 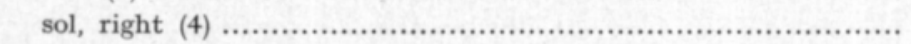 & 17.7 & 3.4 \\
\hline sol, left $(5)$ & 17.5 & 3.4 \\
\hline mean of $1,2,3$ & 18.2 & 3.4 \\
\hline 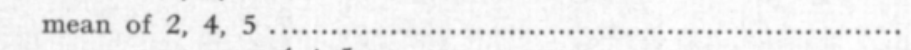 & 17.1 & 3.2 \\
\hline 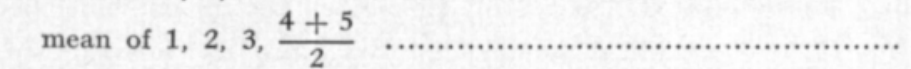 & 18.1 & 3.3 \\
\hline Growth points, old system ...... & 52.8 & 3.4 \\
\hline Fat points, $\quad, \quad$, & 49.3 & 3.5 \\
\hline 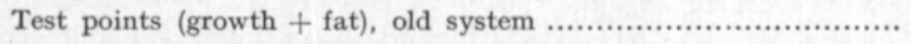 & 102.1 & 2.9 \\
\hline 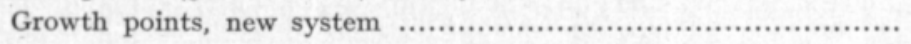 & 52.8 & 1.4 \\
\hline Fat points, $\quad, \quad$, & 51.4 & 5.4 \\
\hline 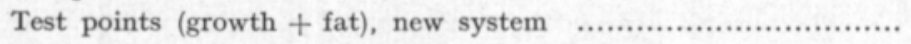 & 104.2 & 5.1 \\
\hline Side length, $\mathrm{cm}$ & 80.8 & 4.3 \\
\hline 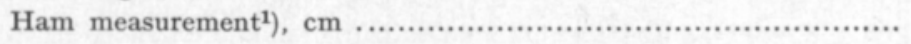 & 107.4 & 5.3 \\
\hline 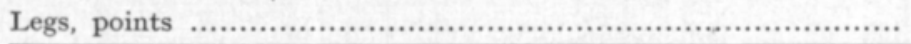 & 3.7 & 0.5 \\
\hline
\end{tabular}

1) Hams measured on 30 boars only; for method, see Fig. 2.

of $0.19-0.23 \mathrm{~mm}$. The greater was the age at ultrasonic measurement, the thinner was the fat, but the effect of age was much less than that of weight. When only the weight at ultrasonic measurement was taken as the regression variable in the least squares analysis, fat thickness (at different measuring points) per kg live-weight, was as follows
(1) withers
$0.19 \mathrm{~mm} / \mathrm{kg}$
(2) midback
0.17

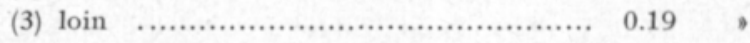

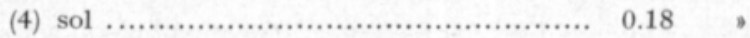

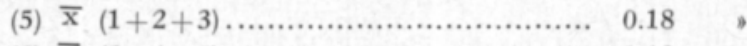
(6) $\bar{x}(2+4+5) \ldots \ldots \ldots \ldots \ldots \ldots \ldots \ldots \ldots \ldots \ldots \ldots \ldots \ldots \ldots \ldots \ldots \ldots \ldots \ldots, 0.18$,

These coefficients were used to correct the fat thickness of the boars selected for progeny testing to a liveweight of $88 \mathrm{~kg}$.

The weight at ultrasonic measurement had a highly significat effect on the test points (old system), in which the thickness of the fat is corrected for age but not for weight (see Figs. 4 and 6). The feed consumption per kg weight 


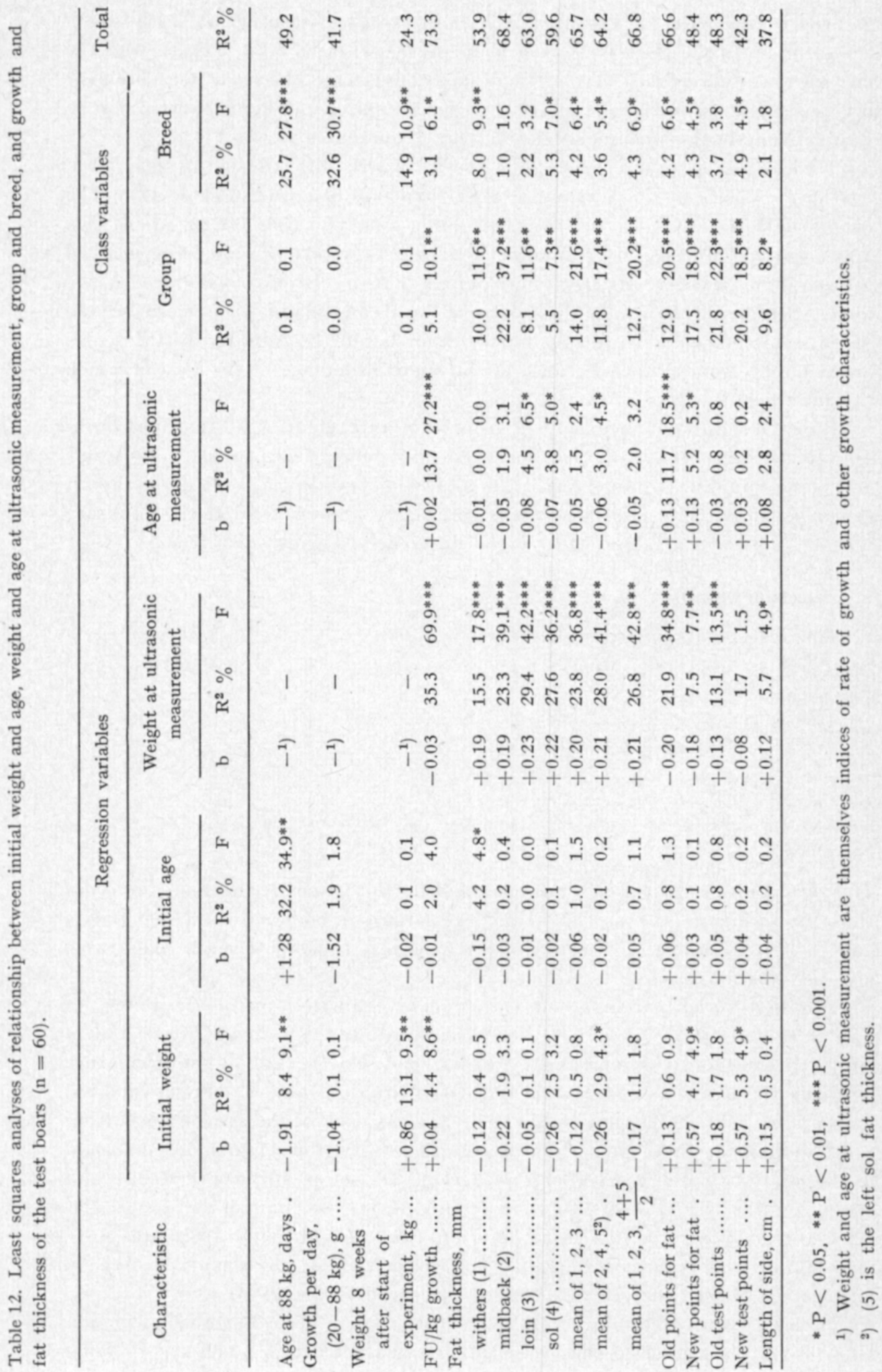


gain decreased with increasing weight at ultrasonic measurement, because in the same litter the fastest growing boars were naturally the biggest, and the fast-growing individuals were efficient feed converters. The age at measurement was positively related to the quantity of feed required per $\mathrm{kg}$ of growth; that is, slow-growing boars consume a relatively large amount of feed.

The two groups of boars (A and B) differed significantly $(\mathrm{P}<$ 0.05 or $\mathrm{P}<0.001)$ in characteristics other than rate of growth (Table 12). The mean fat thickness for Group B was $3.1 \mathrm{~mm}$ less than that for Group A. This appeared to be due mainly to the fact that when the piglets were being selected the requirements were stricter for Group B than for Group A, because of the longer period during which the selection for B was made. The score for the parents was 363.3 for Group A and 610.1 for Group B. Admittedly the scores are not quite comparable, because of the slight difference in the way in which the fat thickness data affect the score.

$\mathrm{Breeds}$ differed primarily in respect of rate of growth: the Yorkshires grew faster than the Landrace boars, the difference being highly significant, and being found in Group B only (Tables 13 and 14). In the Yorkshires the fat thickness at withers and sides was significantly greater than in the Landrace boars. There was no significant breed difference in length of carcass.

\section{b. Selection results}

The test points distributions were as follows:

Group A

Test points

$\begin{array}{llllllllllll}\text { (old system) } & \ldots \ldots \ldots \ldots \ldots \ldots \ldots \ldots \ldots & 96 & 97 & 98 & 99 & 100 & 101 & 102 & 103 & 104 & 105\end{array}$

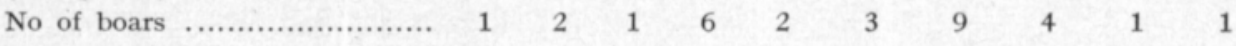

Group $B$

Test points

$\begin{array}{llllllllllllllll}\text { (new system) } & \ldots & 94 & 99 & 101 & 102 & 103 & 105 & 106 & 107 & 108 & 109 & 110 & 114 & 115 & 116\end{array}$

$\begin{array}{lllllllllllllll}\text { No } \text { of boars } \ldots . . . & 1 & 1 & 2 & 4 & 2 & 3 & 3 & 2 & 3 & 2 & 2 & 2 & 2 & 1\end{array}$

The test points (old system) showed a distribution closer to normal than did those according to the new system. The Group A boar with only 96 points had to be withdrawn on account of leg weakness, as were several others with low test points.

The breed and parentage of the progeny-evaluated boars are shown in Tables 13 and 14; in Group A 6 were Yorkshires and 5 were Landrace, and in Group $\mathrm{B}$ the figures were 8 and 7 respectively. On account of the premature loss of boars "Kantti", "Fakiiri" and "Piiska" of Group A they were each evaluated on the basis of 8-9 progeny only (Table 25). As each of the progeny was from a different litter the evaluation was regarded as reliable enough for inclusion in the analysis. The reserve boars of Group B (see p. 40) were "Reka" and "Hymyri", the last two of sub-group I, and "Rata", the first of sub-group III. It is worth noting that the test points for the full and half litter mates were very similar. As regards the quality, in Group A there was a marked division on basis of breed, whereas this was not observed in Group B.

Tables 13 and 14 show the grouping of the boars according to test points. In Group $\mathrm{A}$, the poorest sub-group differed significantly $(\mathrm{P}<0.05$ and $\mathrm{P}<0.01)$ 
from the other sub-groups in respect of test points (old system), rate of growth and feed efficiency. In Group B, the poorest sub-group differed from the others $(\mathrm{P}<0.05$ and $\mathrm{P}<0.01)$ in respect of test points (new system), fat points and thickness of fat; the best and average sub-groups differed significantly $(\mathrm{P}<0.05)$ only in respect of test points (new system). The rank order of Group A boars (old system) was entirely due to the differences in growth points; the mean fat points (old system) of the 3 subgroups were almost the same. This uniformity in fat thickness is seen mainly in average backfat thickness $\bar{x}(1,2,3)$, the two differences being 1.0 and $1.5 \mathrm{~mm}$ respectively. The clear differences in test points between the sub-groups of Group B were due to the fat points (new system), and this in turn was due to the difference (1.4 and $3.8 \mathrm{~mm}$ ) between the average midback- and sol fat $\bar{x}(2,4,5)$. The large differences in growth rate (g/day) among the boars of Group B had no effect upon their grading. For example, "Riku" and "Nakeri", the boars with the slowest growth, were placed in the best sub-group because of their low fat thickness. The growth points (new system), in fact, changed very little $(50-55)$ despite the large differences in rate of growth, which is due to the low gradient of the points scale (Fig. 5). For the sake of comparison, Tables 13 and 14 include points other than those used in grading the boars. It can be seen that if these points had been used the boars of the high and the medium sub-groups would have been interchanged. However, the same boars would have been allocated to the poorest group according to either evaluation.

In quantitating the characteristics of the boars, fat thickness was corrected, to correspond to a liveweight of $88 \mathrm{~kg}$, by using the correction factors given above (p. 50). Accordingly fat thickness is quoted in $\mathrm{mm}$ and $\mathrm{mm} \times 10^{-1}$, though it was measured ultrasonically in mm only.

\section{c. Interrelationships between characteristics}

Old and new test points correlated significantly with all six fat thickness values (Table 15). On the other hand correlations between test points and rate of growth ( $\mathrm{kg} /$ day and age at $88 \mathrm{~kg}$ ) were low.

The effect of each characteristic on the test points was determined by means of stepwise multiple regression analysis (see p. 48), in which all characteristics expressing fat thickness and rate of growth were the independent variables. The effects of differences in weight were eliminated from the data pooled in respect of Group and breed. The following variables provided a statistically significant independent increment of effect:

\begin{tabular}{|c|c|c|c|}
\hline & $\cdots$ & Old te: & \\
\hline Step & Independent variables & $T$ value & $R^{2 \%}$ \\
\hline 1 & Mean fat thickness $\bar{x}(1,2,3) \ldots$ & $-22.81 * * *$ & 90.1 \\
\hline 2 & 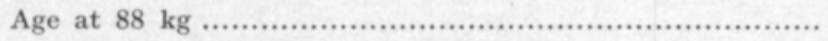 & $-7.06 * * *$ & 8.6 \\
\hline 3 & 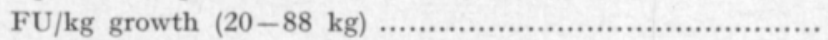 & $+3.20 * *$ & \\
\hline & 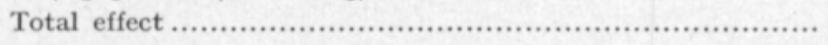 & & 91: \\
\hline & & New $t$ & \\
\hline 1 & Mean fat thickness $\bar{x}(2,4,5)$ & $-34.57 * * *$ & 95.4 \\
\hline 2 & 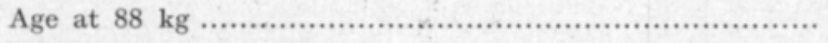 & $-5.87 * * *$ & 2.7 \\
\hline 3 & 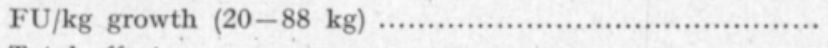 & $+1.99^{*}$ & \\
\hline & Total effect ....................... & & \\
\hline
\end{tabular}




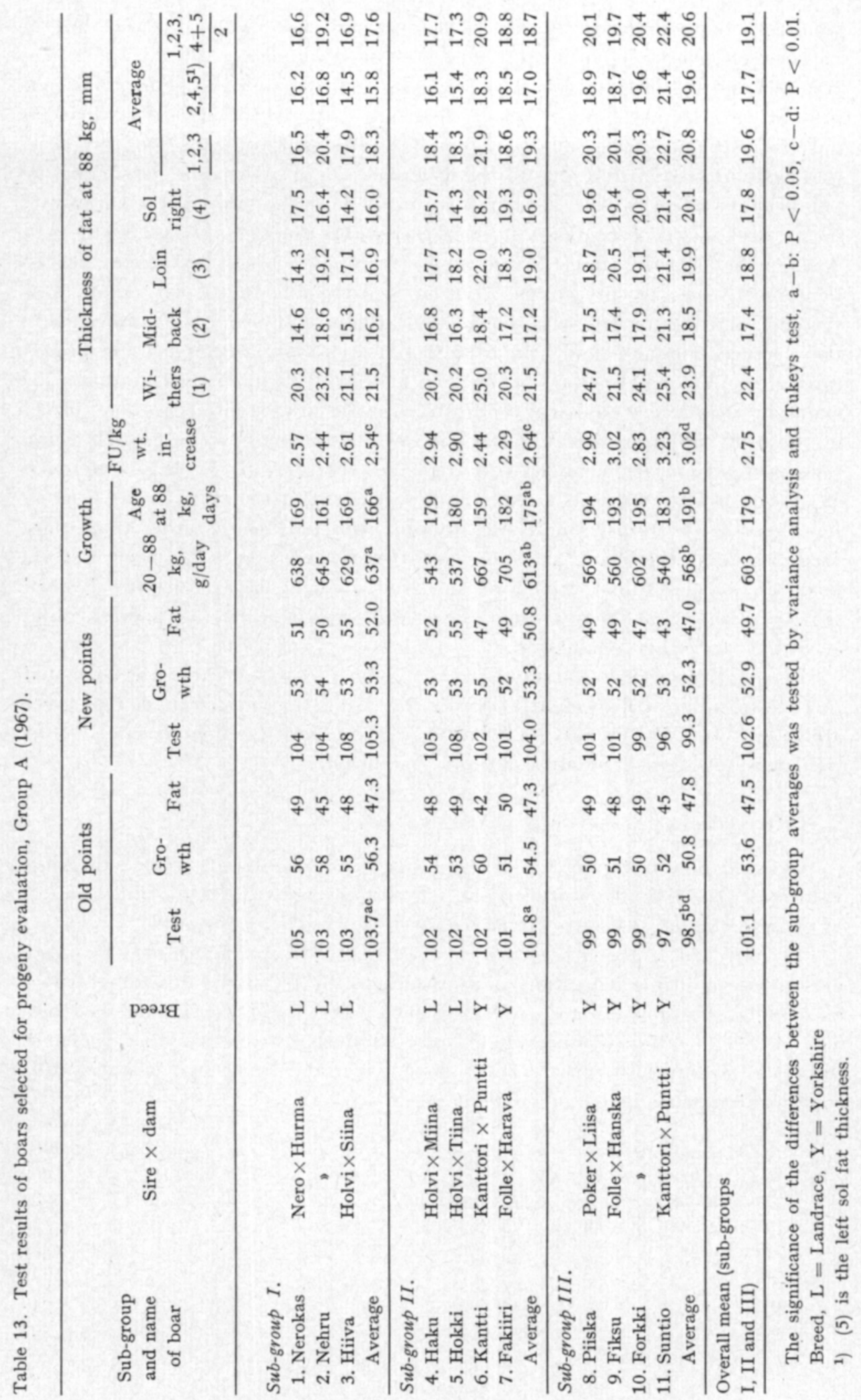




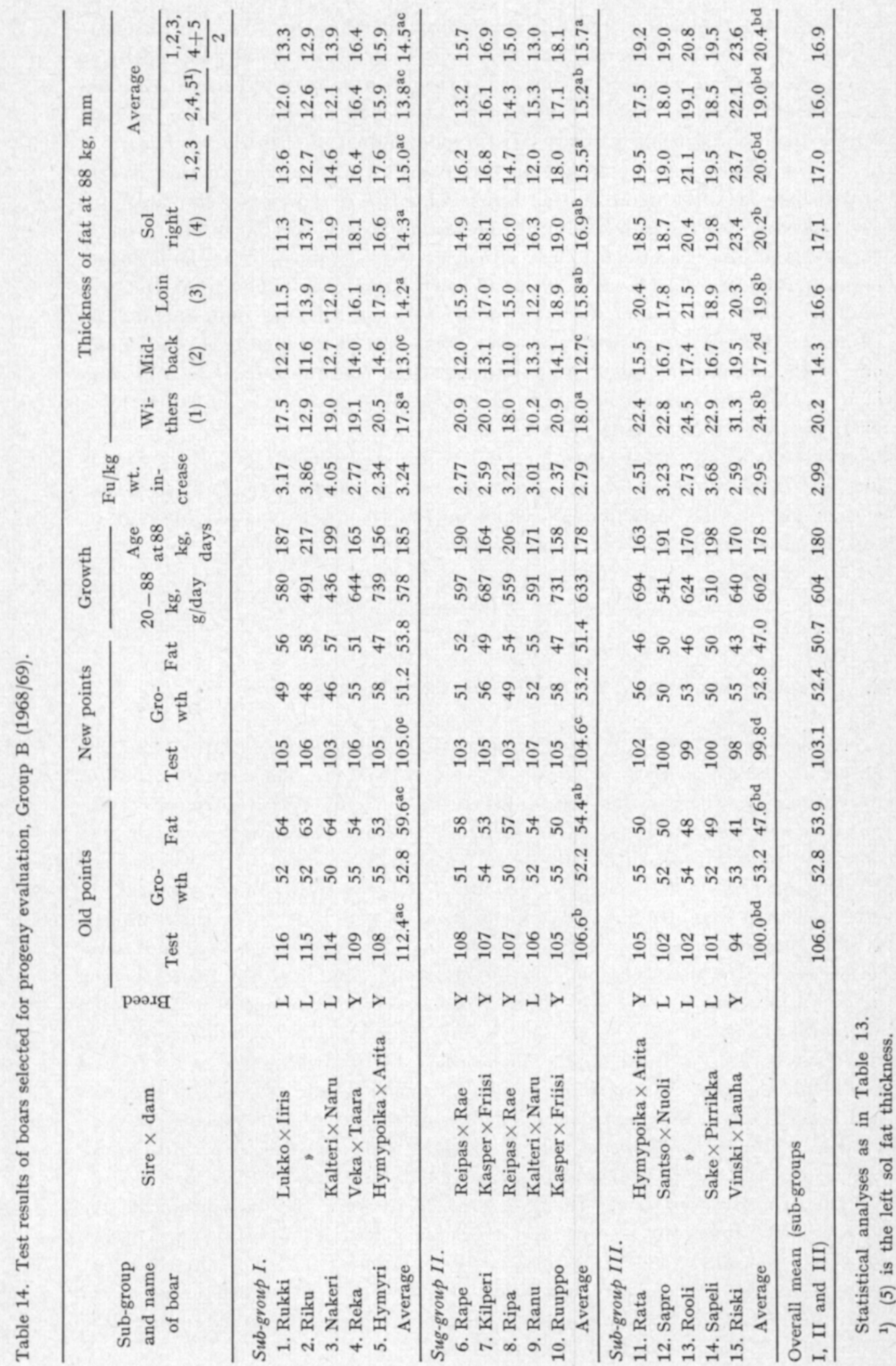


Thus, variation in fat thickness accounted for almost all of the variation in both old and new test points. New test points were more closely dependent on fat thickness than were old test points. Despite the low correlations, the age at a weight of $88 \mathrm{~kg}$ was of significance in accounting for variation in both sets of test points, being a characteristic independent of the others. The effect of rate of growth (age at $\mathbf{8 8 ~} \mathrm{kg}$ ) on test points was greater than that of the growth per day (not significant), because when the test points were calculated the total age, not the growth during the testing period, was taken into account (Figs. 3 and 5). The effect of feed efficiency was significant, but the influence is undesirable from a breeding point of view: animals with low feed efficiency obtained high test points, because of the low fat thickness and the high fat points of these slow-growing boars (see Table 14). Feed quality was obviously one of the reasons for the slow growth and high consumption of feed of some boars. The feed mixture in question (Table 8) sometimes caused diarrhoea, at these and other testing stations.

Feef efficiency and growth per day correlated closely $\left(\mathrm{r}_{\mathrm{p}}=-0.84^{* * *}\right)$, due partly to autocorrelation. The different fat thickness values, too, were closely interrelated, and the ultrasonic measurements of fat at different locations gave highly consistent results (Table 15).

\section{Progeny}

a. Phenotype evaluation: results and factors affecting them

Altogether $142(72 \mathrm{Y}+70 \mathrm{~L})$ progeny of the boars of Group A and 299 $(161 \mathrm{Y}+138 \mathrm{~L})$ progeny of Group B were evaluated. Those from Group A were barrows, whereas there were 134 boars and 165 barrows from B. The imbalance with regard to Group B arose because the replacements were barrows, only one boar in each litter not being castrated.

The initial weights of the two groups of progeny were almost identical, as were the final weights, but the progeny from A were older than those from B at the commencement of testing (Table 16). The slower growth and lower feed efficiency of the A progeny is probably mainly due in to the poorer feeding used initially (see p. 44). An attempt was made to eliminate the disrupting effects of change in feed on the A progeny evaluation by dividing them into three categories, i.e. those on the old feeding standard (43 pigs), new (59) and both (40), and then pooling these before data analysis. Every boar of Group A had progeny in all three categories, but the number of animals in each category varied. Differences between testing stations did not affect the differences between boars, for no boar had progeny at both stations.

The progeny grew faster than the sires (Tables 11 and 16), primarily due to the more abundant feeding and the higher feed quality for the former (Tables 7 and 10). Like the Yorkshire sires of Group B, the Yorkshire progeny grew faster than the Landrace progeny (Table 16). Boar-progeny grew faster than the barrows. Since the progeny were group fed there is no data concerning individual differences in feed consumption. 


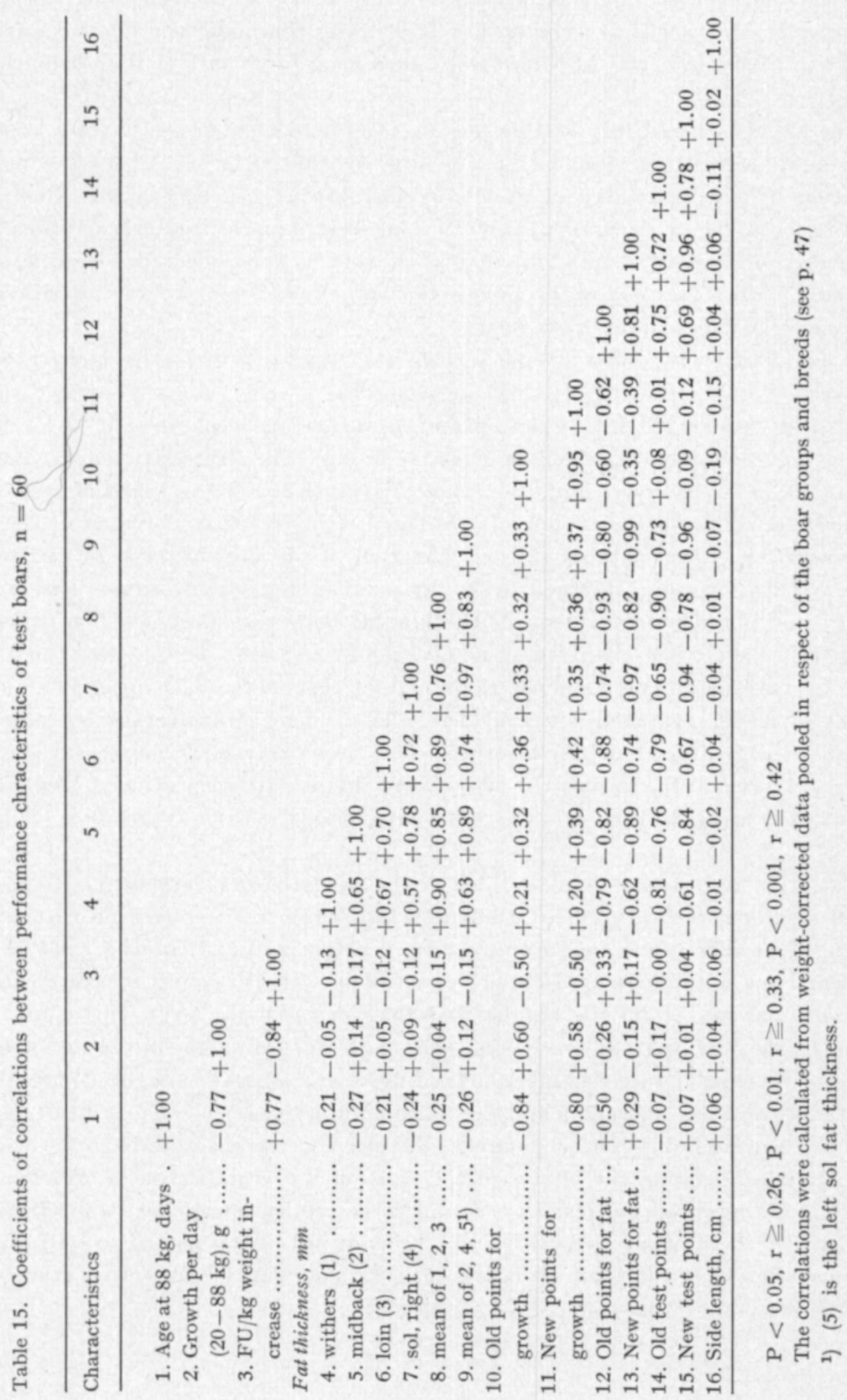


Initial weight had a significant effect on the rate of growth of the progeny (Table 17). Pigs starting at a high weight achieved a live-weight of $88 \mathrm{~kg}$ at an early age, even though their growth per day at the station was lower than that of pigs of low initial weight. For A progeny the negative effect of initial weight on daily gain was apparent only during the first part of the evaluation period.

The effect of hereditary factors on rate of growth of B progeny was statistically highly significant (Table 17). The sires accounted for $17.0 \%$ of the total variation in daily gain day of the B progeny (Table 17). When the effect of the sires was taken as class variable in the least squares analysis, it masked the breed differences completely. Since the boars were selected according to quality of sire, irrespective of breed, the "breed differences" were, basically, differences between individual boars.

8 weeks after the start of the testing the weight of the B progeny-boars was very close to the expected $60 \mathrm{~kg}$, but that of the progeny-barrows was about $2 \mathrm{~kg}$ less (Table 18). The appropriate ultrasonic measurement was for both categories taken at a weight of about $88 \mathrm{~kg}$. The less restricted feeding, the inclusion of barrows, and the genetic level of the dams together caused an increase in the thickness of the fat of the progeny, so that the layer of fat of the progeny was considerably thicker than that of the sires (Tables 14 and 18). Therefore the progeny obtained fewer fat points than did the sires. The high growth points did not make up for the low fat points, so that the progeny's test points were lower than the sires' (Tables 11 and 18). The fat layer of the barrows was significantly thicker than that of the boars. The difference at a weight of $88 \mathrm{~kg}$ averaged $4.4 \mathrm{~mm}$ (Table 18). The boars' average leg points was slightly greater than the barrows'. The sires' average ham measurement was greater than the progeny's $(107.4$ and $101.9 \mathrm{~cm})$ respectively; for the progeny, the mean for the boars was $103.5 \mathrm{~cm}$ and for the barrows $100.7 \mathrm{~cm}$ (Table 18).

Variation in initial weight and age of the progeny had very little effect on the ultrasonically measured fat thickness (Table 19). The effect of variation in weight at ultrasonic measurement was highly significant in the early test but much less in the regular test. The effect of age at ultrasonic measurement, however, was greater in the regular test than in the early test. This contrast is due to the fact that the early test was made according to number of days, whereas the regular test was made according to the animal's weight. When the effects of variation in weight and age were eliminated by means of linear regressions, and the differences between the progeny boars and barrows were eliminated by pooling, the effects of the sires on the variation in fat thickness values in the preliminary test were found to be highly significant, while in the regular test these effects were highly significant only with regard to variation in loin fat thickness. The effect on loin fat is reflected in the respective averages of both fat points and test points (Table 19). 


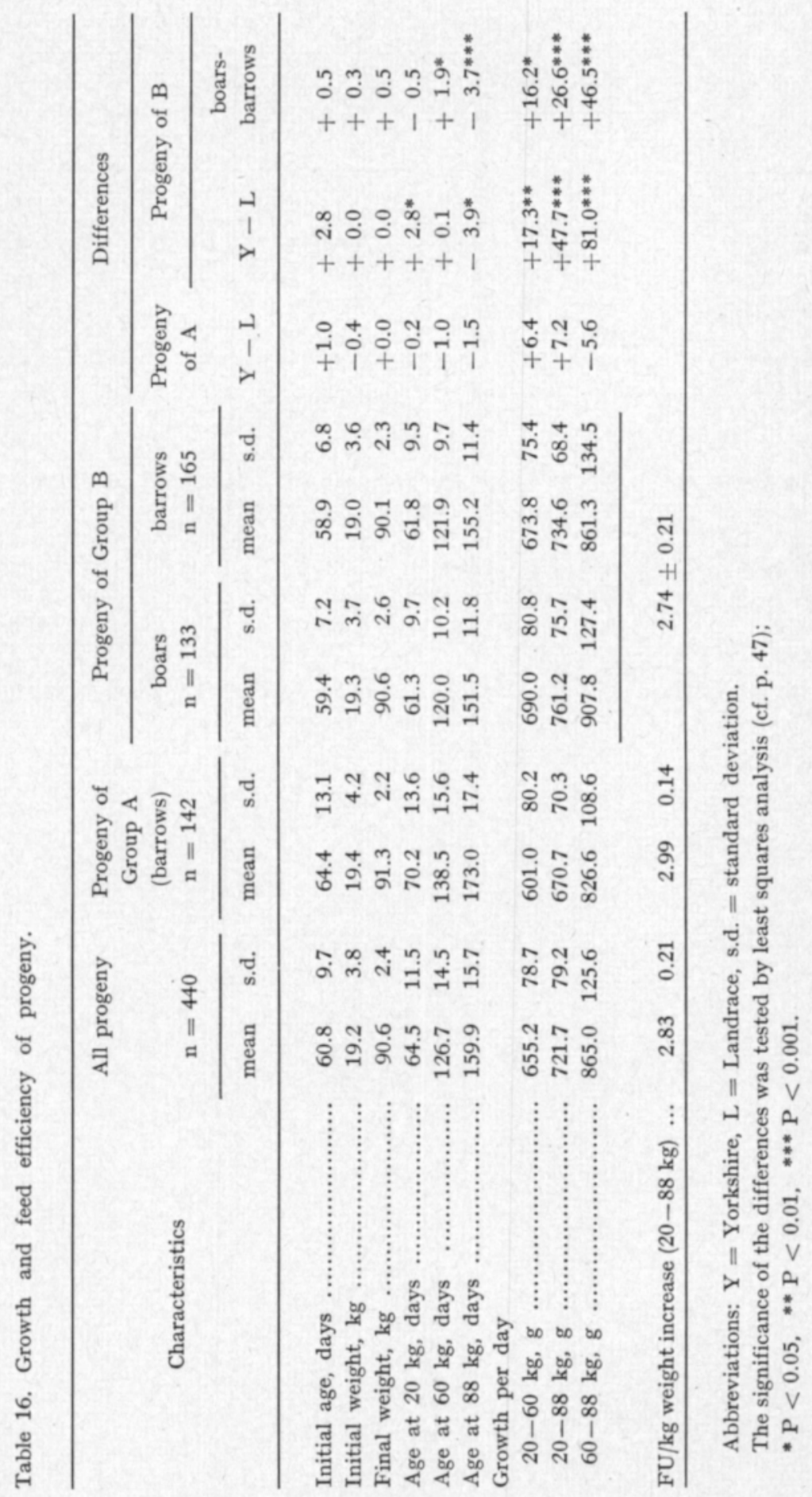


Table 17. Least squares analysis of the effects of initial weight, initial age and sires on the growth of boar progeny.

\begin{tabular}{|c|c|c|c|c|c|c|c|c|c|}
\hline \multirow{3}{*}{ Characteristics } & \multicolumn{6}{|c|}{ Regression variables } & \multirow{2}{*}{\multicolumn{2}{|c|}{$\frac{\text { Class variables }}{\text { Sires }}$}} & \multirow{3}{*}{$\begin{array}{l}\text { Total } \\
\mathrm{R}^{2} \%\end{array}$} \\
\hline & \multicolumn{3}{|c|}{ Initial weight } & \multicolumn{3}{|c|}{ Initial age } & & & \\
\hline & $\mathbf{b}$ & $\mathrm{R}^{2} \%$ & $\mathbf{F}$ & $\mathbf{b}$ & $\mathrm{R}^{2} \%$ & F & $\mathrm{R}^{2} \%$ & $\mathbf{F}$ & \\
\hline \multicolumn{10}{|l|}{ Group $A, n=142$} \\
\hline Age at $60 \mathrm{~kg} . \ldots . .$. & -1.53 & 13.4 & $24.6^{* * *}$ & +0.49 & 12.1 & $22.1 * * *$ & 7.8 & 1.4 & 30.6 \\
\hline Age at $88 \mathrm{~kg} \ldots \ldots .$. & -1.84 & 15.6 & $28.3 * * *$ & +0.55 & 12.7 & $23.0 * * *$ & 5.6 & 1.0 & 29.8 \\
\hline \multicolumn{10}{|c|}{ Growth per day } \\
\hline $20-60 \mathrm{~kg} \ldots \ldots \ldots$ & -0.01 & 11.8 & $18.1^{* * *}$ & +0.00 & 0.6 & 0.9 & 4.6 & 0.7 & 17.0 \\
\hline $20-88 \mathrm{~kg} \ldots \ldots \ldots$ & -3.13 & 2.8 & 3.8 & -0.10 & 0.0 & 0.0 & 3.2 & 0.4 & 6.5 \\
\hline $60-88 \mathrm{~kg} \quad \ldots \ldots$. & +0.01 & 5.4 & $7.5^{* *}$ & -0.00 & 2.1 & 3.0 & 2.9 & 0.4 & 8.9 \\
\hline \multicolumn{10}{|l|}{ Group $B, n=299$} \\
\hline Age at $60 \mathrm{~kg} \ldots \ldots .$. & -1.89 & 40.5 & $290.4 * * *$ & +0.90 & 26.8 & $192.1^{* * *}$ & 6.1 & $3.1 * * *$ & 60.8 \\
\hline Age at $88 \mathrm{~kg} . \ldots . .$. & -1.99 & 33.5 & $189.0^{* * *}$ & +0.89 & 19.4 & $109.5^{* * *}$ & 10.6 & $4.3 * * *$ & 50.2 \\
\hline \multicolumn{10}{|l|}{ Growth per day } \\
\hline $20-60 \mathrm{~kg} . \ldots \ldots \ldots$ & -0.01 & 6.1 & $21.8^{* * *}$ & +0.00 & 0.3 & 1.2 & 11.1 & $2.8 * * *$ & 20.8 \\
\hline $20-88 \mathrm{~kg} \ldots \ldots \ldots$ & -3.77 & 3.2 & $11.7 * * *$ & +0.81 & 0.4 & 1.6 & 17.0 & $4.5 * * *$ & 23.6 \\
\hline $60-88 \mathrm{~kg} \ldots \ldots \ldots$ & +0.00 & 0.5 & 1.6 & -0.00 & 0.0 & 0.0 & 12.3 & $2.9 * * *$ & 13.4 \\
\hline
\end{tabular}

The Group A data was pooled according to feeding, and that of Group B according to differences between boars and barrows (see p. 47).

$* \mathrm{P}<0.05, * * \mathrm{P}<0.01, * * * \mathrm{P}<0.001$. 
Table 18. Fat thickness as determined by ultrasonic measurement, ham measurement and leg score of the progeny of Group B: results of preliminary and regular test.

\begin{tabular}{|c|c|c|c|c|c|c|c|}
\hline \multirow{2}{*}{ Characteristics } & \multicolumn{2}{|c|}{$\begin{array}{l}\text { All progeny } \\
\mathrm{n}=299\end{array}$} & \multicolumn{2}{|c|}{$\begin{array}{c}\text { Boars } \\
\mathrm{n}=134\end{array}$} & \multicolumn{2}{|c|}{$\begin{array}{l}\text { Barrows } \\
\mathrm{n}=165\end{array}$} & \multirow{2}{*}{$\begin{array}{r}\text { Differences }^{1} \text { ) } \\
\text { boars-barrows }\end{array}$} \\
\hline & mean & s.d. & mean & s.d. & mean & s.d. & \\
\hline \multicolumn{8}{|l|}{ Preliminary test } \\
\hline 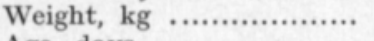 & 58.7 & 5.3 & 59.6 & 5.1 & 58.1 & 5.3 & +1.5 \\
\hline $\begin{array}{l}\text { Age, days } \ldots \ldots \ldots \ldots \ldots \ldots \ldots \\
\text { Fat thickness, mm }\end{array}$ & 122.1 & 47.6 & 122.5 & 51.3 & 121.7 & 44.7 & +0.8 \\
\hline \multicolumn{2}{|l|}{$\begin{array}{l}\text { Fat thickness, } \mathrm{mm} \\
\text { withers (1) } \ldots \ldots \ldots \ldots \ldots \ldots . . .\end{array}$} & 3.2 & 25.0 & 3.3 & 26.3 & 3.0 & $-1.3 * * *$ \\
\hline midback (2) …............ & 12.1 & 2.3 & 11.5 & 2.1 & 12.6 & 2.3 & $-1.1 * * *$ \\
\hline loin (3) $\ldots \ldots \ldots \ldots \ldots \ldots \ldots$ & 12.3 & 2.5 & 11.6 & 2.3 & 12.8 & 2.6 & $-1.2 * * *$ \\
\hline sol,right (4) ................. & 14.4 & 2.3 & 13.6 & 2.0 & 15.0 & 2.3 & $-1.4 * * *$ \\
\hline sol, left (5) $\ldots \ldots \ldots \ldots \ldots \ldots$ & 14.4 & 2.3 & 13.6 & 2.0 & 15.0 & 2.3 & $-1.4 * * *$ \\
\hline mean of $1,2,3 \ldots \ldots \ldots$ & 16.7 & 2.2 & 16.0 & 2.2 & 17.2 & 2.2 & $-1.2 * * *$ \\
\hline mean of $2,4,5 \ldots \ldots \ldots$ & 13.5 & 2.1 & 12.9 & 1.9 & 14.1 & 2.2 & $-1.2^{* * *}$ \\
\hline mean of $1,2,3, \frac{4+5}{2}$ & 16.1 & 2.2 & 15.4 & 2.0 & 16.7 & 2.2 & $-1.3 * * *$ \\
\hline Ham measurement, $\mathrm{cm} . .$. & 85.2 & 13.3 & 87.2 & 5.9 & 83.6 & 16.9 & $+3,6$ \\
\hline Forelegs, points ............. & 4.5 & 0.6 & 4.5 & 0.6 & 4.5 & 0.6 & \pm 0 \\
\hline Back legs, points ........... & 4.1 & 0.8 & 4.2 & 0.7 & 4.1 & 0.8 & \pm 0.1 \\
\hline \multicolumn{8}{|l|}{ Regular test } \\
\hline Weight, kg ................... & 88.1 & 4.0 & 88.4 & 3.9 & 87.8 & 4.0 & +0.6 \\
\hline Age, days ....................... & 153.2 & 12.1 & 151.4 & 12.1 & 154.6 & 12.0 & -3.2 \\
\hline \multicolumn{8}{|l|}{ Fat thickness, mm } \\
\hline withers (1) $\ldots \ldots \ldots \ldots \ldots \ldots$ & 35.0 & 4.6 & 32.5 & 3.6 & 37.0 & 4.4 & $-4.5 * * *$ \\
\hline midback (2) $\ldots \ldots \ldots \ldots \ldots . . .$. & 18.1 & 3.8 & 15.8 & 3.0 & 20.0 & 3.3 & $-4.2 * * *$ \\
\hline 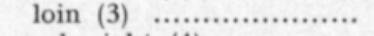 & 18.4 & 4.4 & 16.0 & 3.3 & 20.4 & 4.1 & $-4.4 * * *$ \\
\hline sol, right (4) ................ & 21.9 & 4.3 & 19.4 & 3.7 & 23.9 & 3.7 & $-4.5^{* * *}$ \\
\hline sol, left (5) ................. & 21.9 & 4.3 & 19.4 & 3.6 & 23.9 & 3.7 & $-4.5 * * *$ \\
\hline mean of $1,2,3 \ldots \ldots \ldots$ & 23.9 & 3.8 & 21.4 & 2.9 & 25.8 & 3.3 & $-4.4 * * *$ \\
\hline mean of $2,4,5 \ldots \ldots \ldots$ & 20.7 & 3.9 & 18.2 & 3.2 & 22.6 & 3.3 & $-4.4 * * *$ \\
\hline mean of $1,2,3, \frac{4+5}{2}$ & 23.4 & 3.7 & 20.9 & 2.9 & 25.3 & 3.2 & $-4.4^{* * *}$ \\
\hline Ham measurement, cm ... & 101.9 & 11.0 & 103.5 & 4.2 & 100.7 & 14.2 & +2.8 \\
\hline Forelegs, points ............. & 4.3 & 0.7 & 4.4 & 0.6 & 4.2 & 0.8 & +0.1 \\
\hline Back legs, points $. . . \ldots \ldots . .$. & 3.8 & 0.8 & 3.9 & 0.8 & 3.7 & 0.9 & +0.2 \\
\hline Test points, old system .... & 98.6 & 4.5 & 101.4 & 3.7 & 96.3 & 3.7 & $+5.1 * * *$ \\
\hline Growth points, old system & 58.0 & 2.8 & 58.6 & 2.9 & 57.5 & 2.7 & +1.1 \\
\hline Fat points, old system ... & 40.6 & 4.1 & 42.8 & 3.5 & 38.7 & 3.5 & $+4.1 * * *$ \\
\hline Test points, new system . & 100.3 & 8.0 & 105.3 & 6.5 & 96.3 & 6.6 & $+9.0^{* * *}$ \\
\hline Growth points, new system & 55.9 & 1.4 & 56.1 & 1.4 & 55.7 & 1.4 & +0.4 \\
\hline Fat points, new system .... & 44.4 & 7.6 & 49.2 & 6.3 & 40.6 & 6.3 & $+8.6^{* * *}$ \\
\hline
\end{tabular}

1) Least squares analysis; effects of variation in initial weight, initial age, and weight and age at ultrasonic measurement were eliminated by means of linear regressions, ${ }^{*} \mathrm{P}<0.05$, ** $\mathrm{P}<0.01,{ }^{* * *} \mathrm{P}<0.001$. 


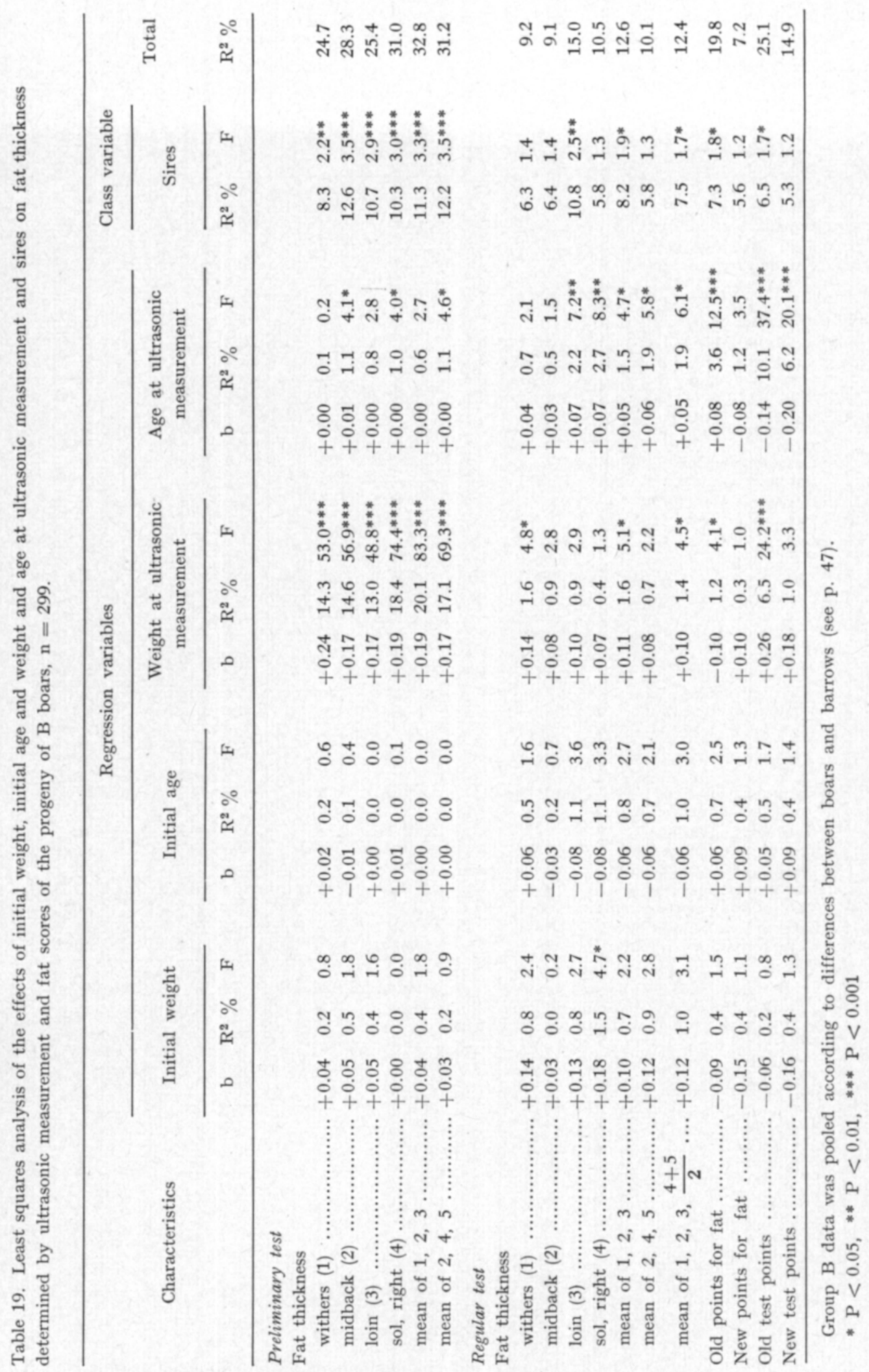


b. Carcass evaluation and lean cuts results of progeny

The progeny were slaughtered at an average weight of $90.6 \mathrm{~kg}$ (Table 16); the average carcass weight was $66.9 \mathrm{~kg}$ (Table 20). In the conventional carcass evaluation (Fig. 7) the fat measurements were taken at locations as close as possible to those at which the ultrasonic measurements of fat had been made. The location at which the loin fat had been ultrasonically measured corresponded to $3 \mathrm{~b}$, that is the mid loin. Ultrasonically measured fat thicknesses were $0.8-1.5 \mathrm{~mm}$ less than the corresponding thicknesses measured on the carcass (Tables 18 and 20). The differences in the thickness of carcass fat between the progeny boars and the progeny barrows were almost identical to those obtained by ultrasonic measurement. The progeny of Group A had a higher fat thickness than those of group B. Correspondingly, the cross-sectional area of the longissimus muscle for A was smaller than for B, and for the barrows smaller than for the boars. The boars had significantly longer carcasses than the barrows' (Table 20).

Variation in initial weight and age of the progeny had no effect on carcass measurements (Table 21). Variation in carcass weight, however, was highly significant, accounting for much of the variation in most of the characteristics. The effects of variation in carcass weight were much greater that those of the variation in weight at ultrasonic measurement (Tables 19 and 21). The more accurate fat measurements and weighing results, and the differences in slaughter losses (Table 20), evidently increased the effect of weight in accounting for variation in the thickness of fat. When the effects of differences in weight were eliminated by means of linear regressions, and the effects of feed and boarbarrow differences were eliminated through pooling, the differences between the sires were found to have a highly significant effect on most of the carcass fat values (Table 21). The sires accounted for $8.1-29.0 \%$ the overall variation in the thickness of carcass fat in Group A, and for $9.1-16.7 \%$ in Group B. With regard to side fat the influence of the sires was the least, and for withers fat in Group A and for loin fat in Group B the greatest. Sire differences were much more pronounced in the carcass fat values of the progeny than in the ultrasonic fat measurements of the live animal (Tables 19 and 21). The sire differences were highly significant in accounting for variation in side length. Sire differences accounted for $14.3 \%$ of the total variation in the cross-sectional area of the longissimus muscle in Group A, and for $17.8 \%$ in Group B (Table 21).

In the lean cuts analysis (Fig. 8) the most valuable parts of the half carcass (ham, loin, back, foreback and shoulder) were divided into two parts, namely meat + bone and fat + skin. The total weight of the meat + bone plus fat + skin is given as a percentage of the weight of the half carcass in Table 22. These percentages give the best picture of the meatiness and fatness of the carcass. By dividing the total weight of the meat + bone component by the age in days the daily yield of valuable parts produced was got. The fatness or meatiness of the carcass has was also expressed as the weight ratio (fat + skin): (meat + bone) as totals for the most valuable parts of the carcass. A carcass score, Y, derived from meatiness and meat yield, was calculated from $Y=\frac{10 \mathrm{~A}^{2}}{B C}$, 


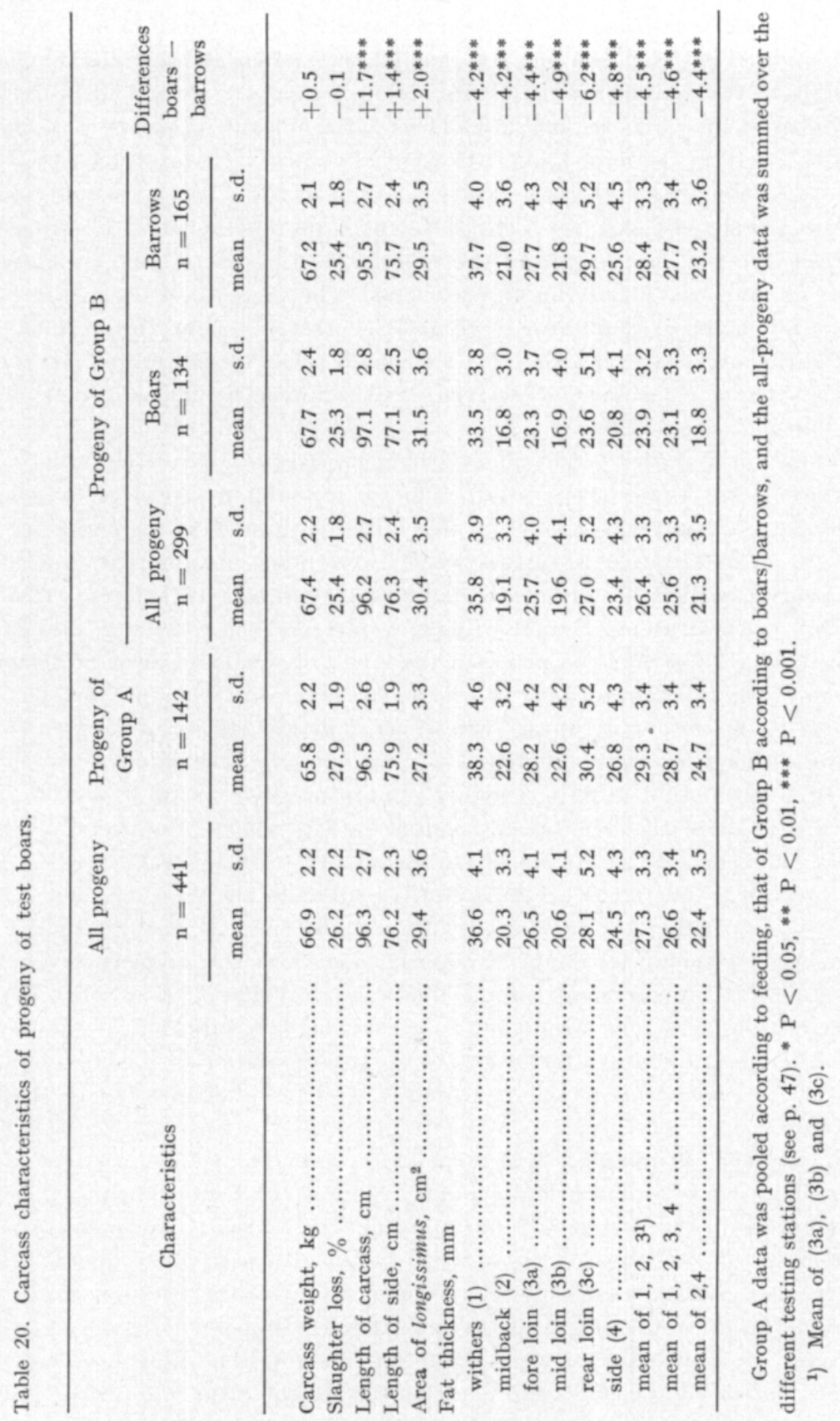




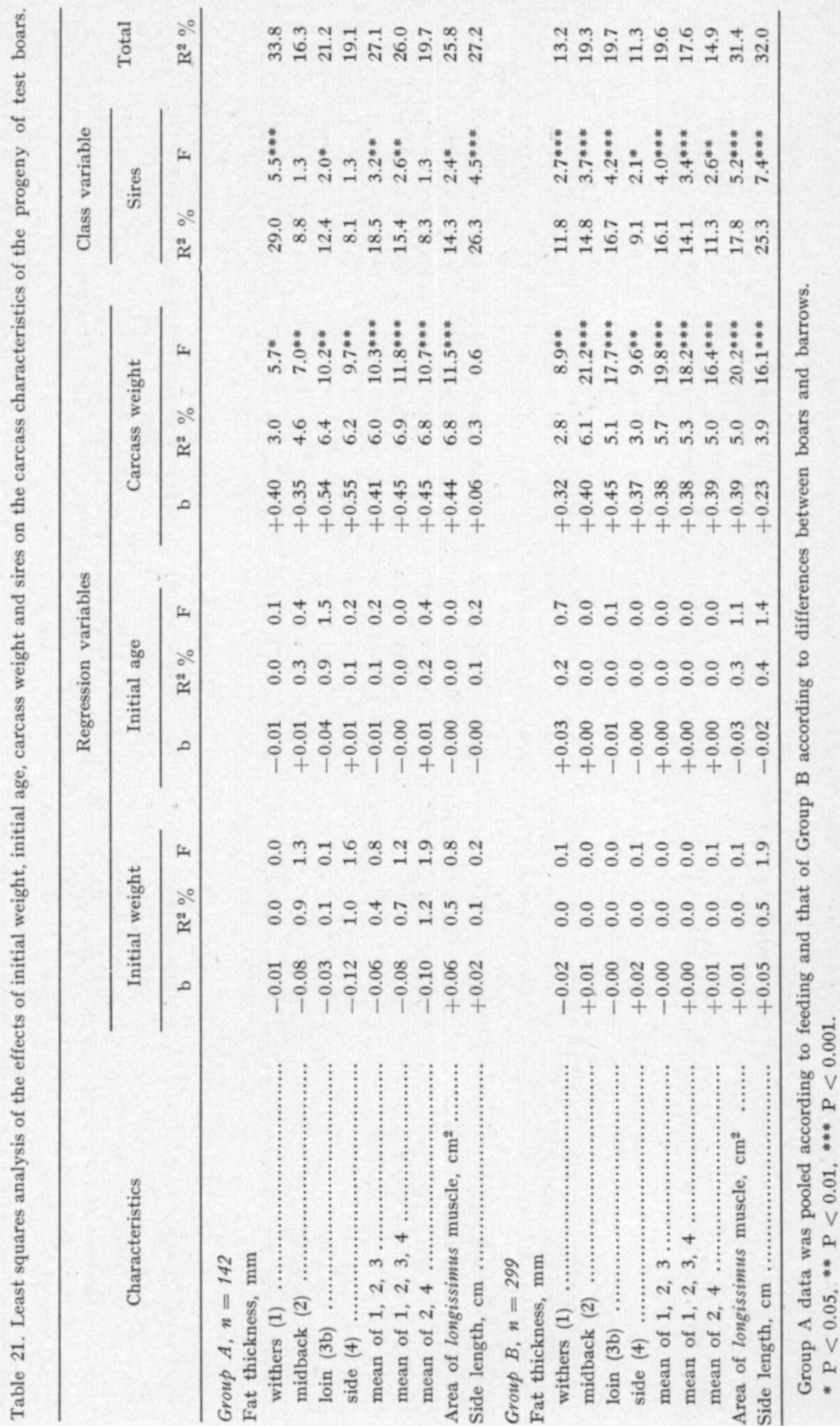




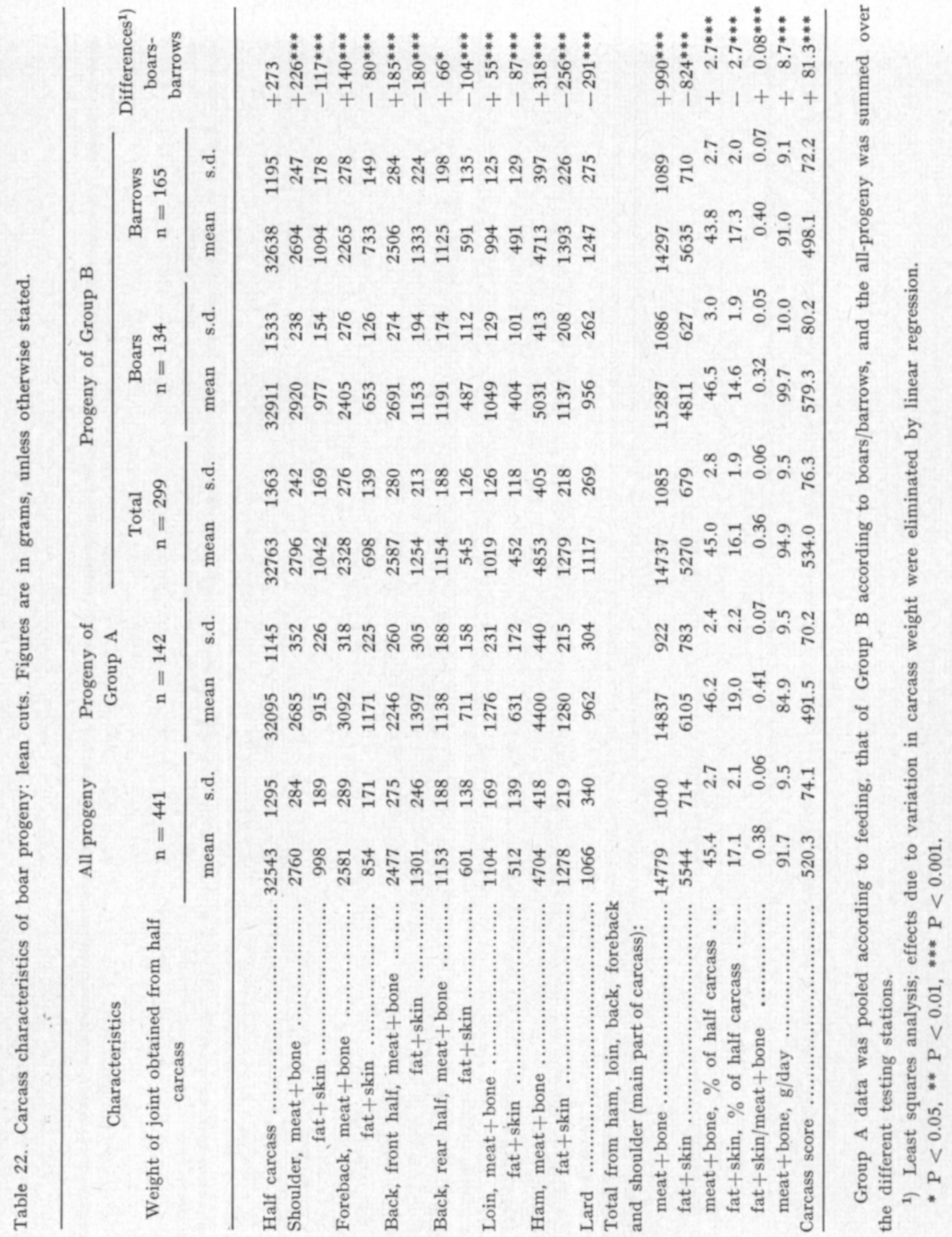


where $\mathrm{A}$ is the weight in $\mathrm{g}$ of the meat+bone of the valuable parts of the half-carcass, $\mathrm{B}$ is the age in days at slaughter minus half the age in days at a liveweight of $20 \mathrm{~kg}$, and $\mathrm{C}$ is the weight of the half carcass in $\mathrm{g}$.

This carcass score is in general use in Finland; the period of growth is divided by two in order to reduce the effect of growth under uncontrolled conditions.

Total meat+bone as a fraction of the most valuable part of the carcass as well as the fat +skin component in percent of the carcass was for A progeny higher than for the $\mathrm{B}$ barrows. The fat:meat ratio (fat + skin $/$ meat + bone) of the two sets of barrows, however, was almost identical $(0.40-0.41)$. The meat yield per day and the carcass score of the B barrows were higher than for the A progeny, this being the result of the faster growth of the former. For the boars, meatiness was significantly greater and fatness significantly less than for the barrows. The boars' meat yield (99.7 g/day) and carcass score (579.3) were likewise significantly higher than were those of their barrow sibs (91.0 g/day and 498.1) (Table 22).

Variation in initial weight and age had no effect on the lean cuts results (Table 23). However, these factors had a highly significant effect on the daily meat yield and, in the B progeny, on the carcass score, which is to be expected because these characteristics depend on the early rate of growth. Variation in carcass weight had a significant effect on the lean cuts results, i.e. mainly on the weight results (Table 23).

When weight variation was eliminated by means of linear regression, and feed variation in the A progeny and boar-barrow differences for B were eliminated by pooling, the sire differences accounted for $5.8-21.3 \%$ of the total variation of the characteristics expressing carcass value. The sire effect was very uniform $\left(\mathrm{R}^{2}=11.0-19.3 \%\right)$ and highly significant for all carcass characteristics in B progeny, while in A progeny it was highly significant only in yield of shoulder and back meat (Table 23).

3. Results of phenotype and carcass evaluation and lean cuts analysis of progeny, classified in accordance with grade of sire

The progeny are classified in Tables $24-27$ in the same order as the sires in Tables 13 and 14. The poorest sub-group (III) of the boars of Group A, ranked according to old test points, proved to be the poorest also in the progeny's fat thickness and meatiness (Tables 24 and 25). There were statisically significant differences between sub-groups I and III and/or II and III in withers and loin fat, cross-sectional area of the longissimus muscle and yield of meat + bone. It can be noticed that the sub-groups did not differ, in contrast to the sires, in rate of growth and feed efficiency characteristics. Neither were there, because of the uniform rate of growth, significant differences between the sub-groups in respect of meat + bone yield per day or carcass score. Subgroups I and II did not differ significantly in respect of any of the characteristics. This was the case also for the sires. 


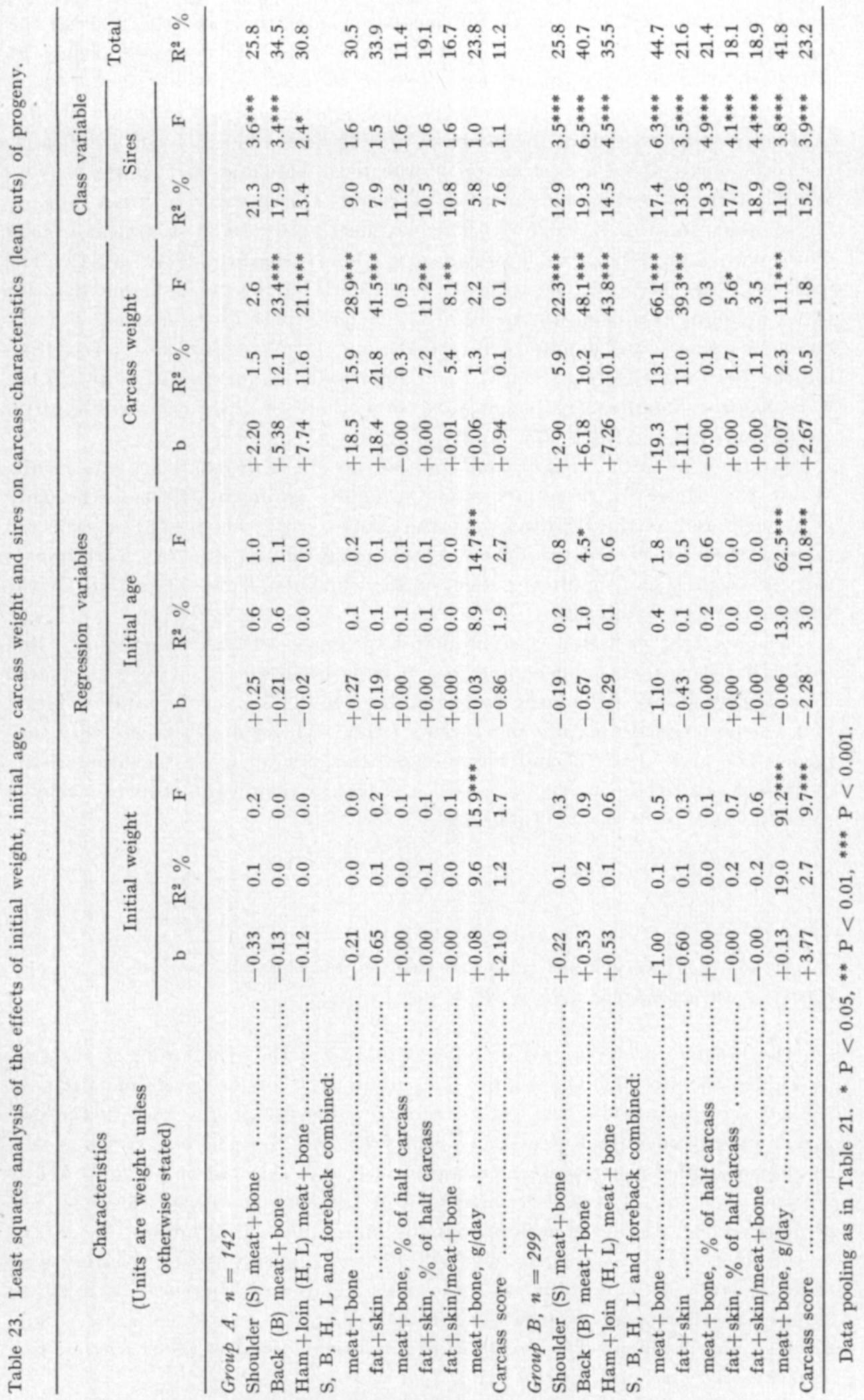




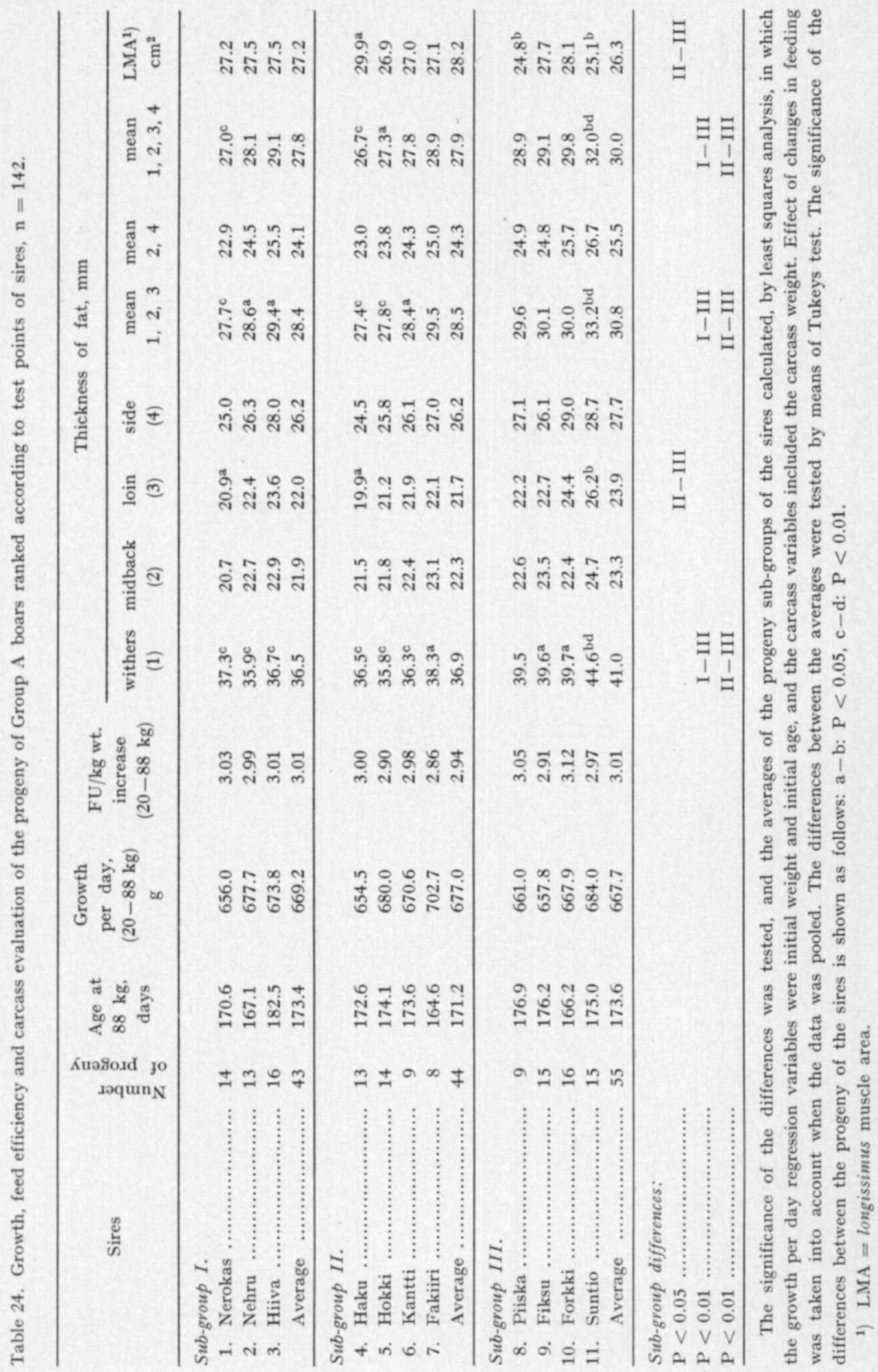




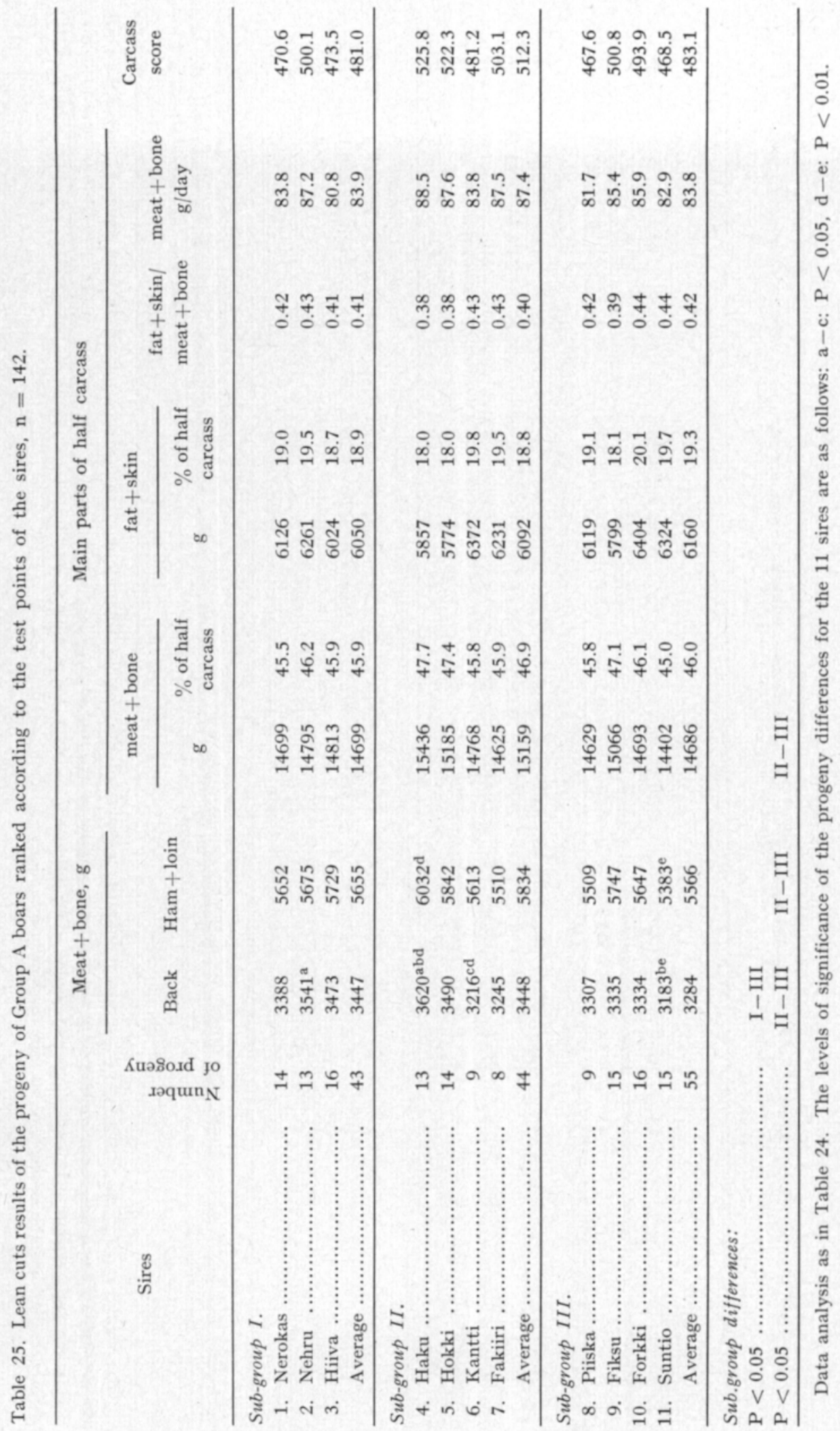


The poorest sub-group (III) of the Group B boars, ranked according to new test points, also proved to be the poorest in the progeny's lean cuts results and cross-sectional area of the longissimus muscle (Tables 26 and 27). The daily yield of meat + bone and the carcass score of sub-group III were significantly $(\mathrm{P}<0.01)$ smaller than those of group II. Sub-group III, however, did not differ significantly from the others in respect of fat thickness (Table 26). The only significant difference in fat thickness was that between the ultrasonically measured loin fat of I and II. As for the sires, the rate of growth of the progeny in sub-group I was lowest and that of II highest (Tables 14 and 26). The subgroup differences in rate of growth and feed efficiency, however, were not statistically significant (Table 26).

A least squares analysis was also made of the differences between individual sires on the basis of the progeny results. The progeny of "Suntion, the poorest boar of Group A, differed significantly from most of the others in their thicker layer of fat and lower meatiness (Tables 24 and 25). The half sibs "Haku and "Hokki" obtained the best carcass scores on account of their meatiness. The carcass scores did not, however, differ significantly from those of the other boars.

For boars of group B, several of the progeny differences were statistically significant (Tables 26 and 27). Boar "Rata" of sub-group III had the best batch of progeny in respect of rate of growth. "Rata" progeny also had a thin layer of fat and good meatiness, and attained the second best carcass score. "Rata" was one of the reserve boars, and on the basis of its test results it was only slightly below average (Table 14). The progeny of the other boars of subgroup III were significantly poorer than the progeny of the other sub-groups in respect of a number of characteristics. On the other hand, "Reka", of subgroup I, had progeny with poor meatiness (Table 27). "Reka" was also one of the reserve boars and on the basis of phenotype evaluation did not differ much from those of sub-group II (Table 14). The progeny of the top grade boars "Rukki", "Riku" and "Nakeri" were meaty but had low rates of growth, and thus performed according to expectation (Tables 14, 26 and 27).

Sub-group II boars produced progeny of evenly good quality, the average, in fact, being superior to that of I and III. The uniformity was apparently due to the fact that the sires were relatively fast-growing but did not have thick layers of fat (Table 14). The progeny of full and half sibs too proved to be very uniform, even when the sires differed rather clearly (Tables 14 and 27).

It is interesting that the mean fat thickness values of groups I, II and III obtained by ultrasonic measurement differed significantly only in respect of loin fat. Apparently the differences were too small to be measured on the live animal. There were very few significant differences in fat thickness even when measurements were made on the carcass. 


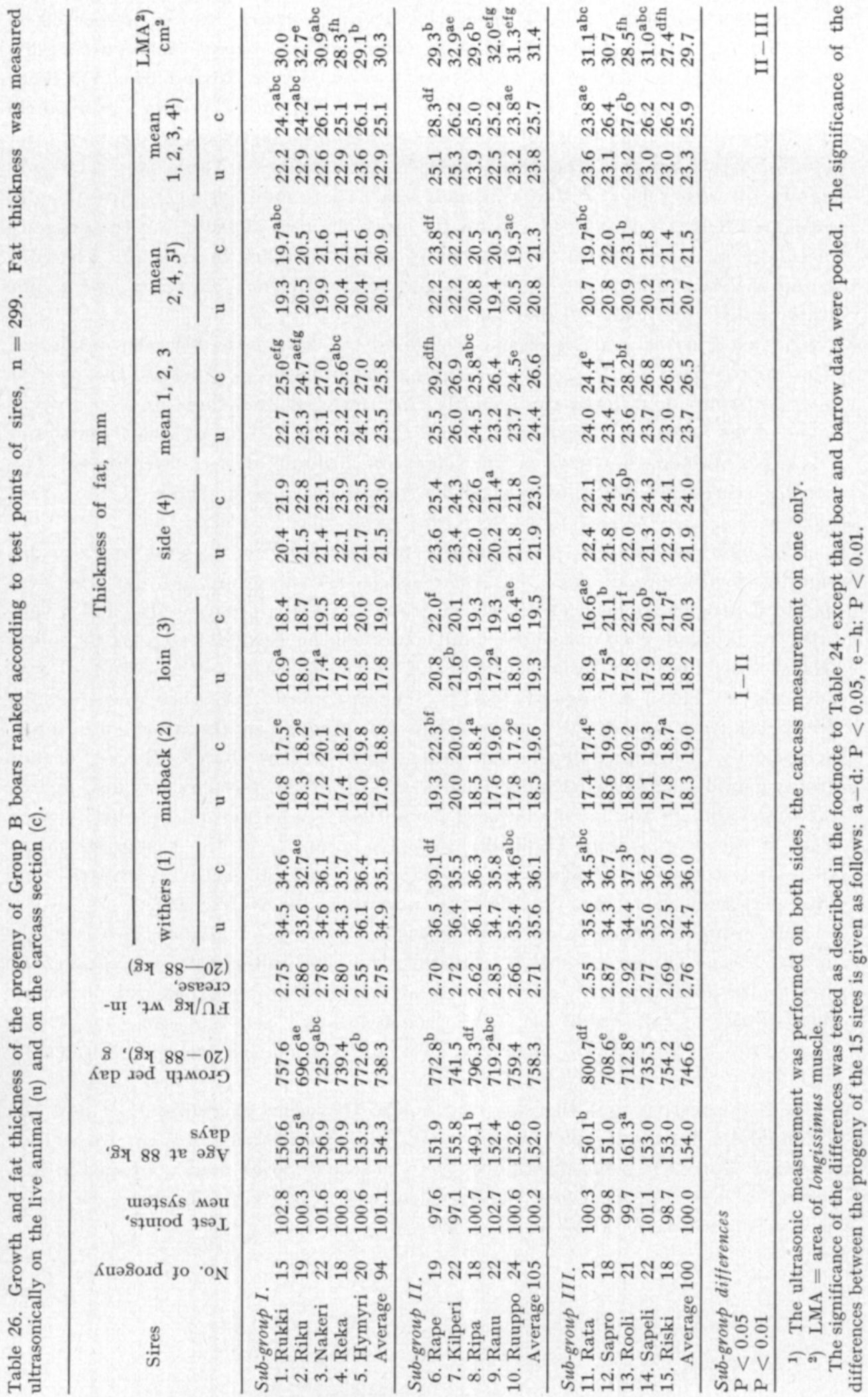




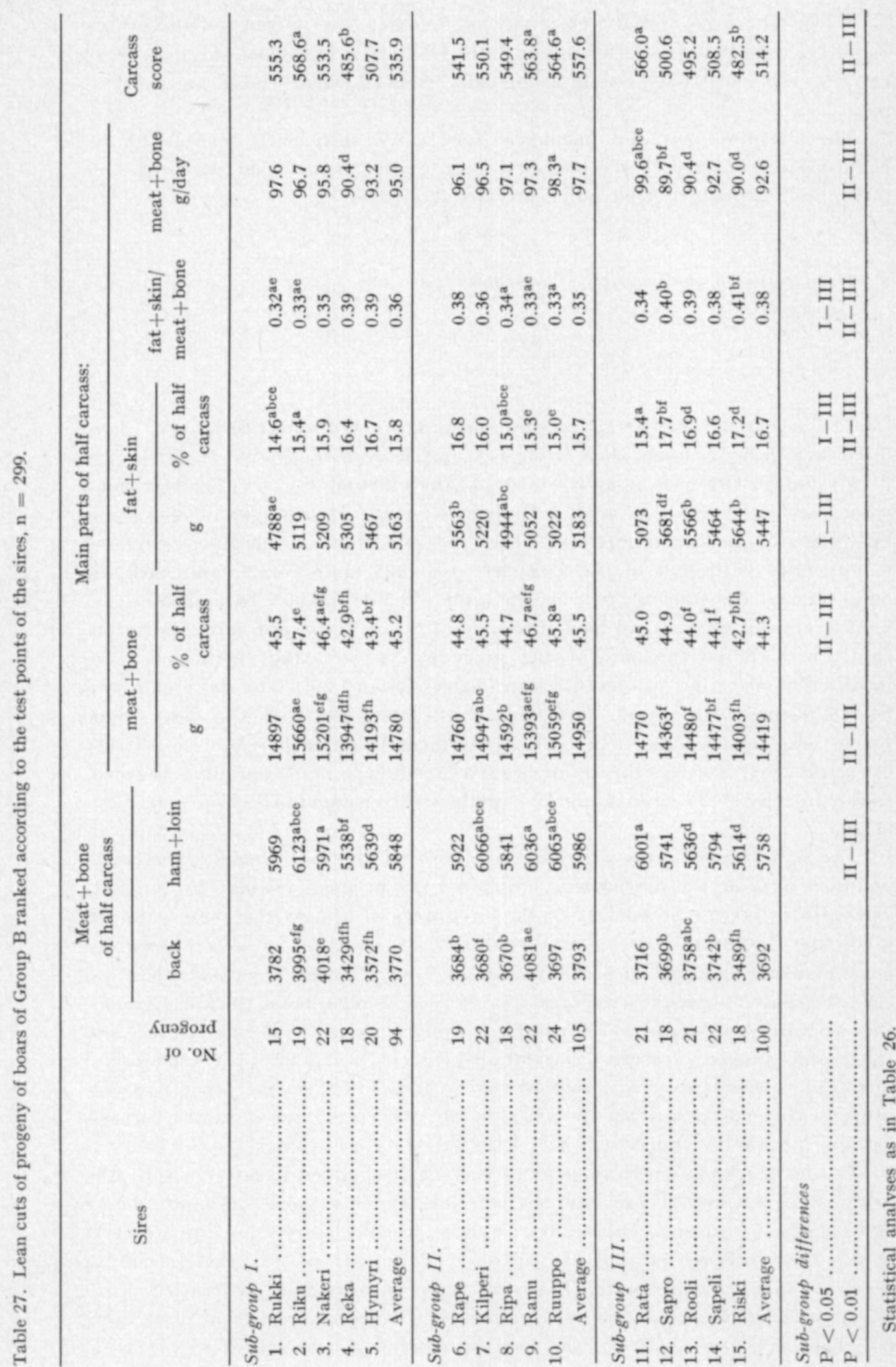


When Groups A and B were analysed together, the progeny of sub-groups I and III were found to differ significantly $(\mathrm{P}<0.001)$ in respect of a number of carcass characteristics, as well as for daily yield of meat + bone and carcass score.

These results show that phenotype testing was sufficiently accurate for recognising the boars with the poorest carcass characteristics, but was not able to improve growth or feed efficiency characteristics.

\section{Heritability of characteristics, and phenotypic and genetic correlations between characteristics}

\section{a. Sire-progeny correlations}

The daily gain $(20-\mathbf{8 8} \mathrm{kg})$ of sires and progeny at the testing station correlated significantly, both when Groups A and B were considered together $(r=$ $\left.0.48^{*}\right)$ and for Group B alone $\left(r=0.50^{*}\right)$ (Tables 28 and 29). On the other hand when rate of growth was analysed in terms of age at a weight of $88 \mathrm{~kg}$ the sire-progeny correlation was low. The feed efficiency of the sires correlated significantly with that of the progeny $\left(r=0.42^{*}\right.$ and $\left.0.49^{*}\right)$, and with the daily gain of the progeny $\left(r=-0.48^{*}\right.$ and $\left.-0.50^{*}\right)$ (Tables 28 and 29).

The rate of growth and feed efficiency of the sires did not correlate significantly with the fat thickness of the progeny. In fact, the coefficients were in different materials of opposite sign (Tables 28 and 29). The daily gain and feed efficiency of the sires correlated significantly only with the meat + bone (back) and meat + bone in percent of the most valuable parts of the carcass of the progeny. Nor was this result, from a breeding point of view advantageous, as the progeny of the sires that grew rapidly and consumed little feed were less meaty.

The fat thickness of the sires had the closest relation to the sidefat and crosssectional area of the longissimus muscle of the progeny (Tables 28 and 29). The various fat measurements of the sires were of almost the same value in predicting the fat thickness of the progeny. The average for all fat thickness measurements of sires and progeny correlated more closely $\left(r=0.42^{*}\right)$ than did the other two fat-thickness averages (Table 29). As regards fat thickness values, the sire (ultrasonic)-progeny (ultrasonic) correlation was not as close as the sire (ultrasonic)-progeny (carcass) correlation (Tables 28 and 29). The least useful ultrasonic measurement was that of the progeny's withers fat, since the sireprogeny correlation was negative (Table 28). When measured on the carcass, withers fat was as valuable as the other fat thickness values (Table 29).

The fat thickness measurements of the sires correlated negatively with the new test points for the progeny, the correlations for withers and loin fat being statistically significant (Table 28). The sire-progeny correlation for new test points was positive but not statistically significant, as was the association between ham measurements. The sires' ham measurement correlated negatively with the fat thickness measurements of the progeny, except for withers fat. The correlation between the ham measurement and sol fat was statisti- 


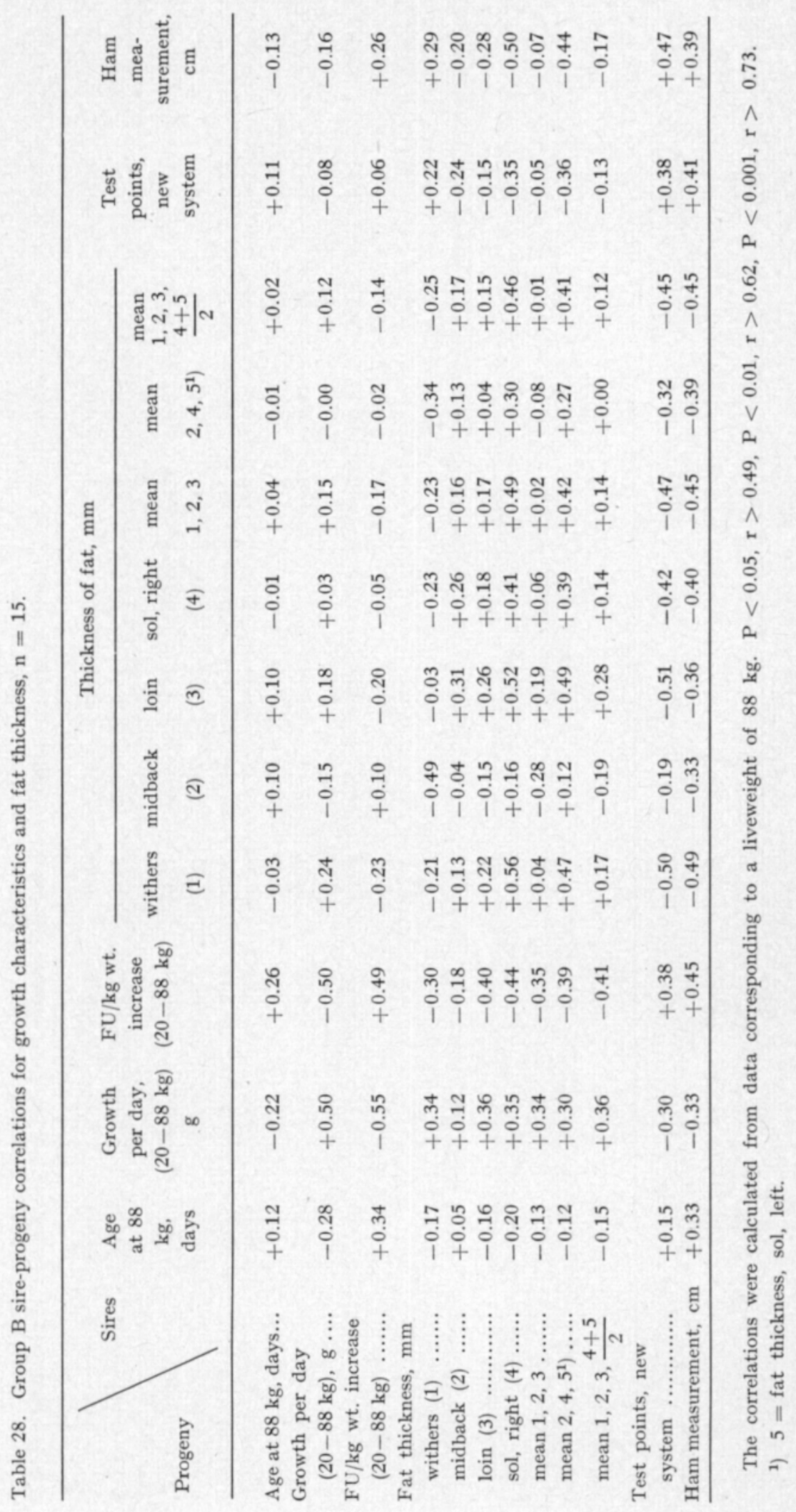




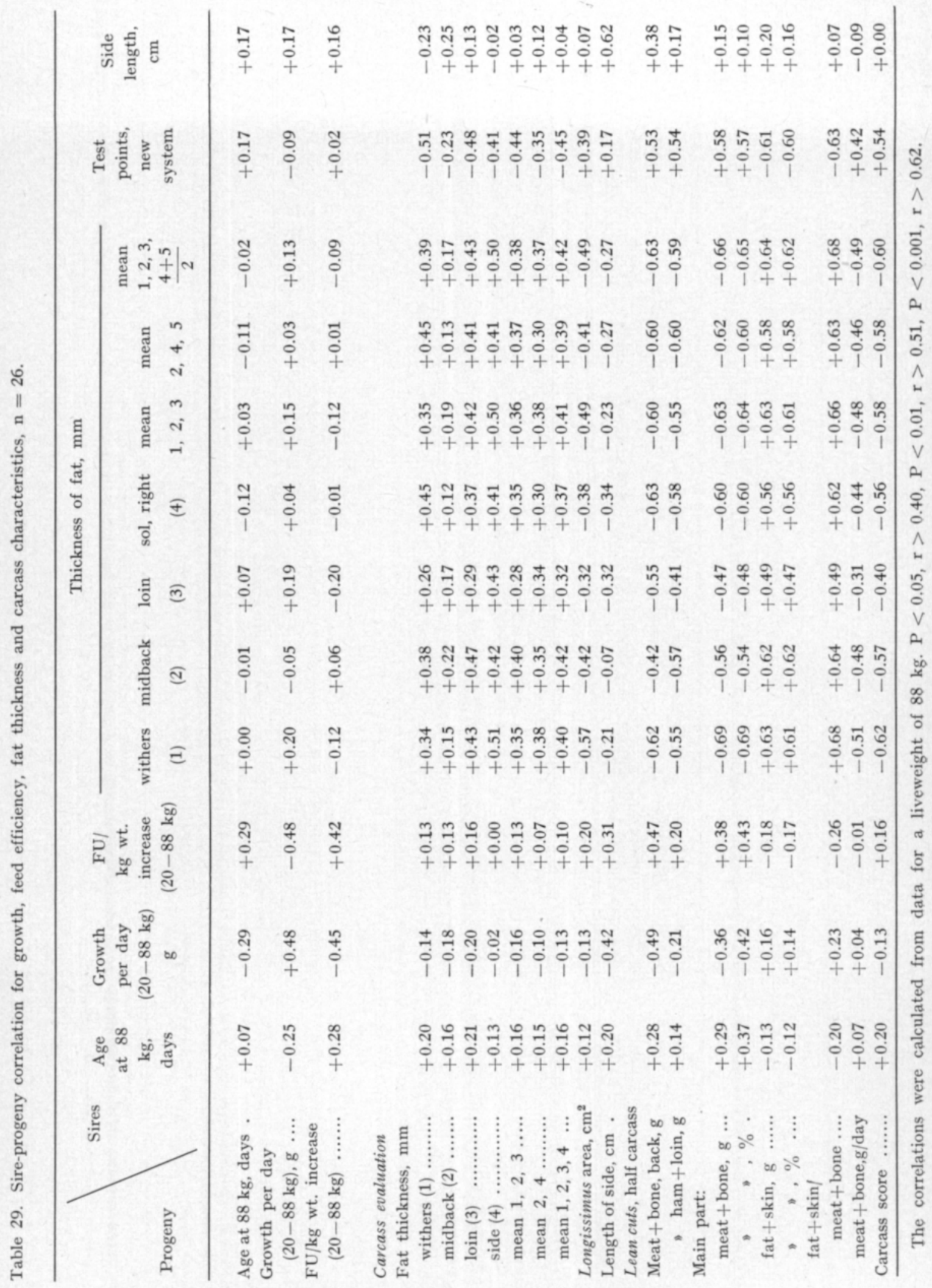


cally significant $(\mathrm{r}=-\mathbf{0 . 5 0 *})$ (Table 28). The side-length of the sires (measured on the live animal) and that of the progeny (carcass measurement) correlated significantly $\left(\mathrm{r}=0.62^{* * *}\right)$ (Table 29).

The correlation between the fat thickness measurements of the sires and the lean cuts results of the progeny was generally very close, being highly significant for most characteristics (Table 29). The progeny's lean cuts results are a better measure of carcass value than ultrasonically measured fat thickness. Therefore it is encouraging to note that the correlation between the ultrasonic measurements on the sires and the carcass measurements on the progeny was quite high. Boars with thin fat produced better progeny than boars with thick fat, even in terms of carcass score $(\mathrm{P}<0.05-\mathrm{P}<0.001)$. The 3 fat thickness averages of the sires were almost equally good in predicting the lean cuts results of the progeny, though the overall average was slightly better (Table 29).

The test points for the sires proved to be very reliable in predicting the meatiness and fatness of the progeny. The progeny characteristic showing the weakest correlation with the fat thickness measurements of the sires was the daily yield of meat + bone $(\mathrm{P}<0.05)$, a result of the low or negative correlation between rate of growth and carcass value.

\section{b. Heritability estimates}

For estimating the heritability $\left(\mathrm{h}^{2}\right)$ of the various characteristics of the live pig and its carcass the amount of data was somewhat limited. But at least it was representative, in the sense that the progeny were distributed at random among a large number of farms, this advantageous situation arising from the use of AI. The sole exception was the three boars mentioned above (p. 44), which were mated with dams on 3-6 farms only. In Group A each sire produced 8-16 progeny (barrows), and in Group B 6-11 boars and $8-11$ barrows (see Tables 24 and 26). Whenever a boar piglet of Group B was replaced with a barrow, one of the other barrows was excluded in the calculations.

The heritabilities were calculated from half sib correlations of the progeny, and from sire-progeny regressions (see p. 48); comparison of the two $\mathrm{h}^{2}$-values obtained shows how reliable the phenotype evaluation was in measuring the breeding value of the sires. The degree of relationship between the half sibs could be taken as $\mathbf{0 . 2 5}$, since, owing to the large number of farms involved, the dams were not closely related. The sire-progeny regressions for fat thickness were calculated from (i) ultrasonic measurements on sires and progeny and (ii) ultrasonic measurements on sires and carcass measurements on progeny (Tables 30 and 31). Similarly, the half-sib correlations were calculated from both ultrasonic and carcass measurements on the progeny.

The differences between the progeny boars and the progeny barrows of Group B were eliminated by pooling when $\mathrm{h}^{2}$ was calculated from the sireprogeny regression. When $\mathrm{h}^{2}$ was calculated from half sib correlations the boars and the barrows were assigned a level of their own in the hierarchic variance analysis. When $\mathrm{h}^{2}$ was calculated from the entire data the differences between 
the two Groups of boars were eliminated either by pooling or by assigning them a level of their own in the hierarchic variance analysis. As to the hierarchic variance analysis, Tables 30 and 31 show the variance of the different levels as percentages of the total variance, and the significance levels of the betweensire differences.

The estimates from the half sib correlations for the daily gain $(20-88 \mathrm{~kg})$ in Group B and Group A + Group B were reliable $(0.67 \pm 0.27$ and $0.49 \pm 0.19$ respectively); the values calculated from the sire-progeny regressions were lower $(0.35$ and 0.32$)$. The age at $88 \mathrm{~kg}$ proved to be an unsatisfactory measure of rate of growth, according to the $\mathrm{h}^{2}$-value. The $\mathrm{h}^{2}$-values for feed efficiency could be calculated from sire-progeny regressions $(0.18$ and 0.25$)$ but, because the animals were group fed, not from half sib correlations (Tables 30 and 31).

The heritabilities of the ultrasonically measured fat thickness measurements were low, only the loin fat value being of any importance (Table 30 ). This result is due primarily to the progeny rather than to the sire measurements, for the $\mathrm{h}^{2}$-values calculated from regressions of ultrasonic measurements (sires) on carcass measurements (progeny) were fairly close to the reliable $\mathrm{h}^{2}$-estimates obtained from the half sib correlations for carcass measurements. With regard to measurements on carcass fat, the $\mathrm{h}^{2}$-values for side and midback fat were the lowest, and those for loin fat in Group B and for withers fat in Groups A+B were the highest. Calculated from the sire-progeny regressions, the $\mathrm{h}^{2}$-values for side fat were higher than from half sib correlations, while in Group B the $\mathrm{h}^{2}$-value for midback fat was zero. The differences in the $\mathrm{h}^{2}$-values for the fat thickness averages were relatively small, for example 0.42 from half sib correlation and 0.44 from sire-progeny regression (Tables 30 and 31 ).

The $\mathrm{h}^{2}$-values from the half sib correlations for side length and ham measurement were quite high, while those from sire-progeny regressions were smaller (Tables 30 and 31 ). Sizeable $\mathrm{h}^{2}$-estimates were obtained from half sib correlations for leg points (Table 30).

The $\mathrm{h}^{2}$ estimates for the lean cuts results, carcass score and the cross-sectional area of the longissimus muscle were all reliable. The highest heritabilities got were for the meat + bone components (Table 31 ).

\section{c. Phenotypic and genetic relations between characteristics}

The phenotypic and genetic correlations between fat thickness (carcass) and lean cuts results are summarised in Table 32 . Withers fat has its closest correlation with meat + bone, whereas loin and side fat are more closely correlated genetically with fat + skin. The genetic correlations between midback fat thickness and lean cuts results were not significant. As regards the fat thickness averages, the genetic correlations of back fat $\bar{x}(1,2,3)$ and total fat $\bar{x}$ $(1,2,3,4)$ with lean cuts results were almost equally high. The phenotypic correlation coefficients for carcass fat $v s$. lean cuts results were almost without exception highly significant. 


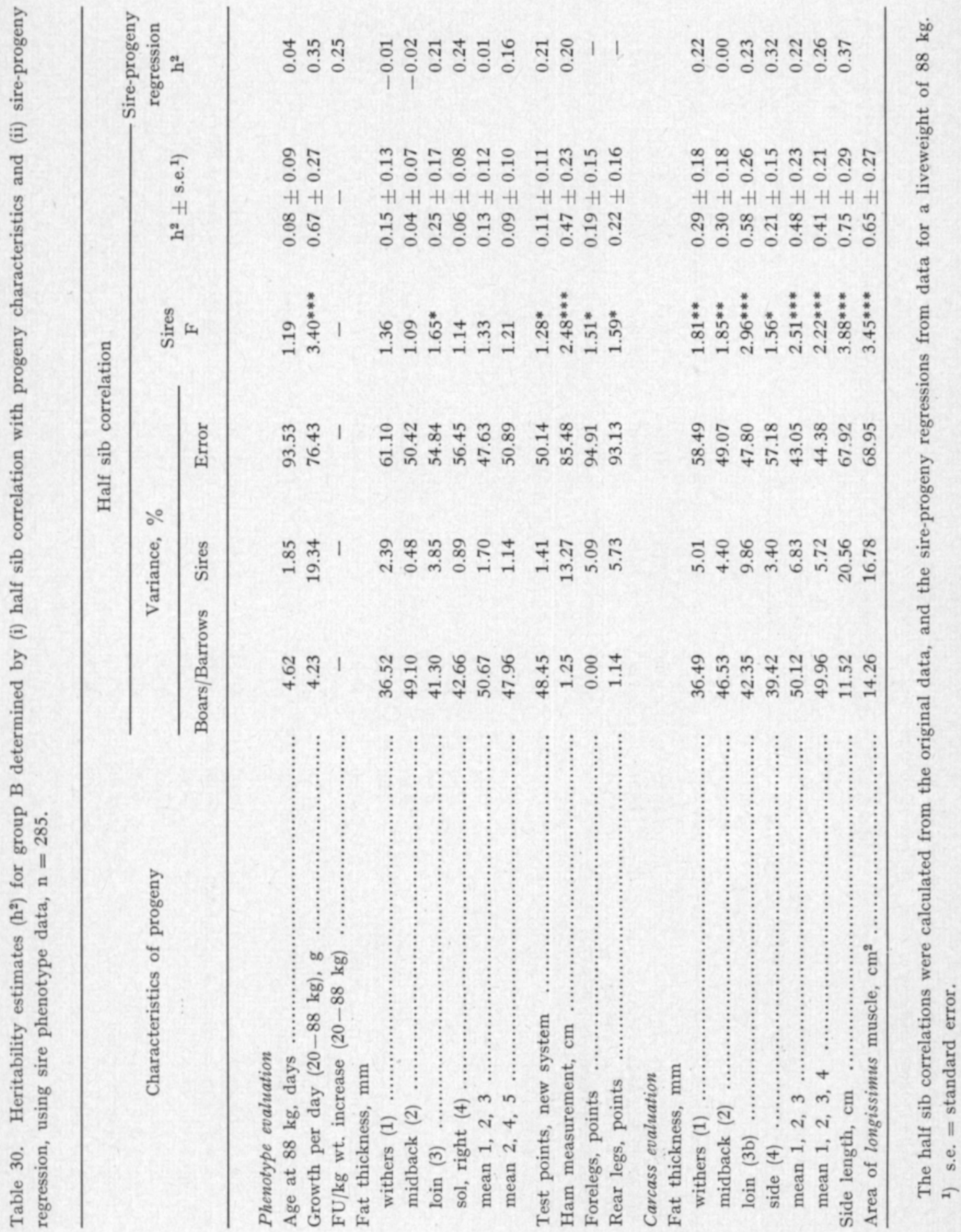




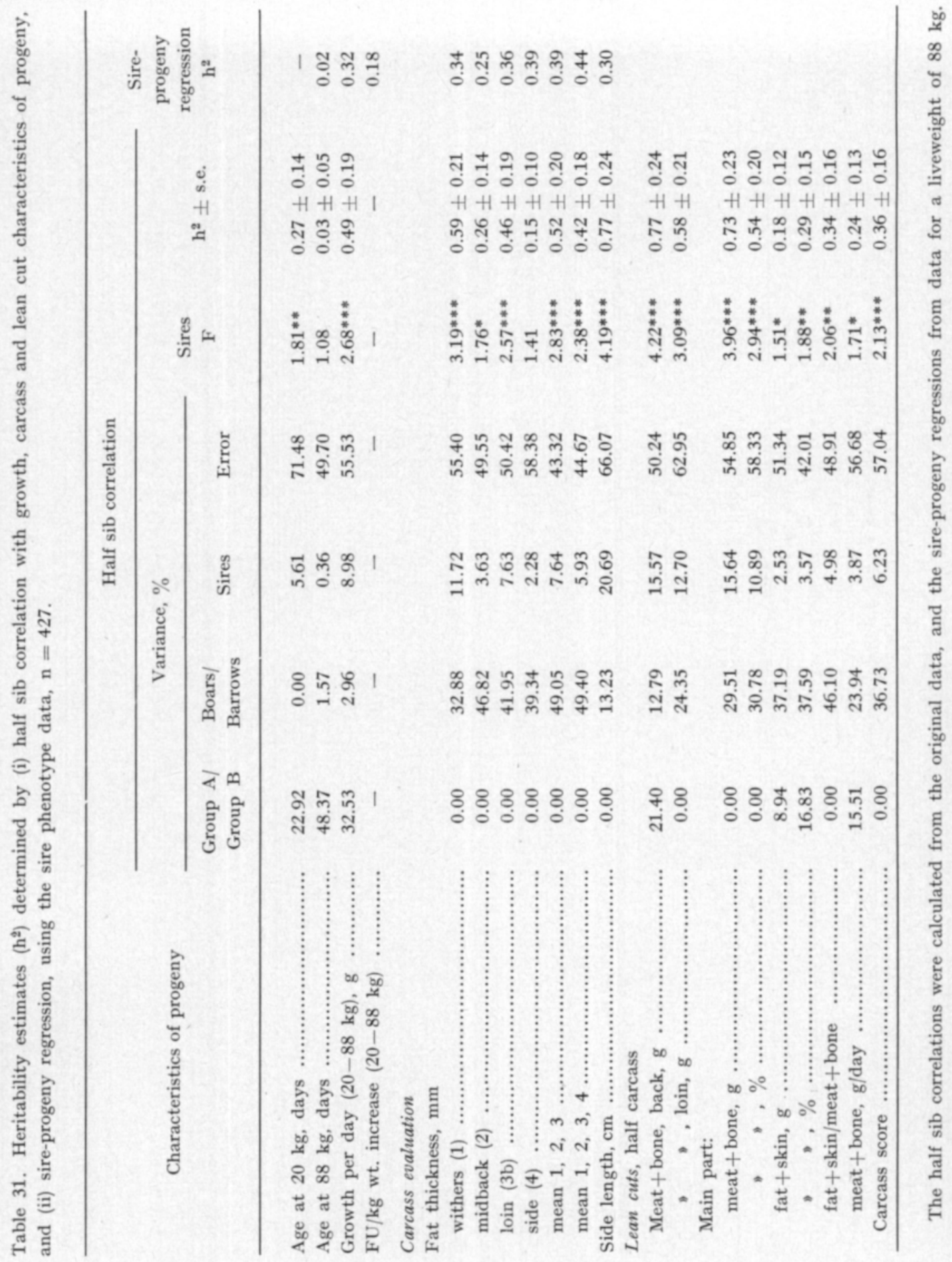


Table 32. Genetic $\left(r_{\mathrm{g}}\right)$ and phenotypic $\left(\mathrm{r}_{\mathrm{p}}\right)$ correlations between fat thickness, measured ultrasonically on live animal and on carcass section, and lean cuts data.

\begin{tabular}{|c|c|c|c|}
\hline \multirow{2}{*}{ Characteristics } & \multicolumn{2}{|c|}{$\begin{array}{l}\text { Fat, carcass/lean cuts } \\
\qquad \mathrm{n}=427\end{array}$} & \multirow{2}{*}{$\begin{array}{c}\text { Fat, ultrasonic } \\
\text { lean cuts, } \\
\mathrm{n}=285 \\
\mathrm{r}_{\mathrm{p}}\end{array}$} \\
\hline & $r_{g} \pm$ s.e. & $r_{p}$ & \\
\hline \multicolumn{4}{|l|}{ Thickness of withers fat (1) } \\
\hline Meat + bone of back .......... & $-0.31 \pm 0.21$ & $-0.22 * * *$ & $-0.12^{*}$ \\
\hline Meat + bone of ham + loin ................ & $-0.39 \pm 0.21$ & $-0.36 * * *$ & -0.09 \\
\hline \multicolumn{4}{|l|}{ Main part of carcass: } \\
\hline meat + bone $\ldots \ldots \ldots$ & $-0.42 \pm 0.20$ & $-0.36 * * *$ & -0.11 \\
\hline meat + bone, $\%$ of carcass $\ldots \ldots \ldots \ldots . .$. & $-0.50 \pm 0.19$ & $-0.45^{* * *}$ & $-0.14^{*}$ \\
\hline 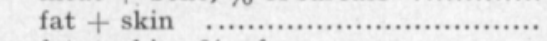 & $0.31 \pm 0.31$ & $0.49 * * *$ & $0.30^{* * *}$ \\
\hline fat + skin, $\%$ of carcass ............... & $0.27 \pm 0.28$ & $0.49 * * *$ & $0.30 * * *$ \\
\hline fat + skin/meat + bone ................. & $0.44 \pm 0.23$ & $0.54 * * *$ & $0.27 * * *$ \\
\hline meat + bone (g/day) $\ldots \ldots \ldots \ldots \ldots \ldots \ldots . . . \ldots . .$. & $-0.49 \pm 0.25$ & $-0.32 * * *$ & -0.08 \\
\hline 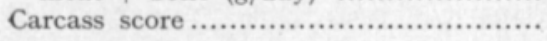 & $-0.49 \pm 0.22$ & $-0.41 * * *$ & $-0.12^{*}$ \\
\hline \multicolumn{4}{|l|}{ Thickness of midback fat (2) } \\
\hline Meat + bone of back .......... & $0.22 \pm 0.28$ & $-0.11^{*}$ & $-0.23 * * *$ \\
\hline Meat + bone of ham + loin $\ldots \ldots \ldots \ldots \ldots . . .$. & $0.03 \pm 0.31$ & $-0.25 * * *$ & $-0.19 * * *$ \\
\hline \multicolumn{4}{|l|}{ Main part of carcass: } \\
\hline meat + bone $\ldots \ldots$. & $0.09 \pm 0.29$ & $-0.23 * * *$ & $-0.23 * * *$ \\
\hline meat + bone, $\%$ of carcass ... & $0.18 \pm 0.31$ & $-0.34 * * *$ & $-0.30 * * *$ \\
\hline fat + skin $\quad \ldots \ldots \ldots \ldots \ldots \ldots \ldots \ldots \ldots \ldots \ldots \ldots \ldots \ldots$ & $0.29 \pm 0.38$ & $0.53^{* * *}$ & $0.52^{* * *}$ \\
\hline fat + skin, $\%$ of carcass ................ & $0.22 \pm 0.35$ & $0.50^{* * *}$ & $0.51 * * *$ \\
\hline fat + skin/meat + bone ................. & $0.08 \pm 0.35$ & $0.50 * * *$ & $0.51 * * *$ \\
\hline meat + bone $(g /$ day) $\ldots \ldots \ldots \ldots \ldots \ldots \ldots . . . \ldots .$. & $-0.30 \pm 0.38$ & $-0.24 * * *$ & $-0.27 * * *$ \\
\hline 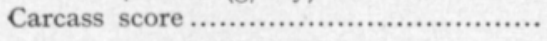 & $-0.05 \pm 0.36$ & $-0.33 * * *$ & $-0.33^{* * *}$ \\
\hline \multicolumn{4}{|l|}{ Thickness of loin fat ( $3 b)$} \\
\hline Meat + bone of back ......... & $-0.07 \pm 0.25$ & $-0.19 * * *$ & $-0.23 * * *$ \\
\hline Meat + bone of ham + loin $\ldots \ldots \ldots \ldots \ldots . .$. & $-0.28 \pm 0.25$ & $-0.35^{* * *}$ & $-0.12^{*}$ \\
\hline \multicolumn{4}{|l|}{ Main part of carcass: } \\
\hline meat + bone $\ldots \ldots \ldots \ldots \ldots \ldots \ldots \ldots \ldots \ldots \ldots \ldots \ldots \ldots \ldots \ldots \ldots \ldots$ & $-0.27 \pm 0.24$ & $-0.34 * * *$ & $-0.18 * * *$ \\
\hline meat + bone, $\%$ of carcass ............ & $-0.27 \pm 0.25$ & $-0.46 * * *$ & $-0.24 * * *$ \\
\hline 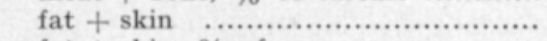 & $0.78 \pm 0.14$ & $0.66 * * *$ & $0.36 * * *$ \\
\hline fat + skin, $\%$ of carcass ................ & $0.65 \pm 0.18$ & $0.64 * * *$ & $0.35 * * *$ \\
\hline fat + skin/meat + bone ................. & $0.58 \pm 0.20$ & $0.66 * * *$ & $0.34 * * *$ \\
\hline 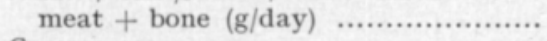 & $-0.71 \pm 0.17$ & $-0.34 * * *$ & $-0.18 * * *$ \\
\hline Carcass score .................................... & $-0.61 \pm 0.19$ & $-0.46 * * *$ & $-0.22 * * *$ \\
\hline \multicolumn{4}{|l|}{ Thickness of side fat (4) } \\
\hline Meat + bone of back ...... & $-0.17 \pm 0.33$ & $-0.27 * * *$ & $-0.35 * * *$ \\
\hline Meat + bone of ham + loin $\ldots \ldots \ldots \ldots \ldots . . .$. & $-0.21 \pm 0.34$ & $-0.41 * * *$ & $-0.36 * * *$ \\
\hline \multicolumn{4}{|l|}{ Main part of carcass: } \\
\hline meat + bone ......... & $-0.23 \pm 0.32$ & $-0.39 * * *$ & $-0.37 * * *$ \\
\hline meat + bone, $\%$ of carcass ............. & $-0.27 \pm 0.34$ & $-0.53 * * *$ & $-0.44 * * *$ \\
\hline 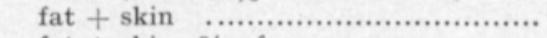 & $0.92 \pm 0.07$ & $0.71 * * *$ & $0.56 * * *$ \\
\hline fat + skin, $\%$ of carcass ............... & $0.71 \pm 0.21$ & $0.69 * * *$ & $0.58 * * *$ \\
\hline fat + skin/meat + bone ................. & $0.63 \pm 0.25$ & $0.71 * * *$ & $0.60^{* * *}$ \\
\hline meat + bone (g/day) $\ldots \ldots \ldots \ldots \ldots \ldots \ldots . . . \ldots . .$. & $-0.57 \pm 0.31$ & $-0.41 * * *$ & $-0.37 * * *$ \\
\hline Carcass score ...................................... & $-0.44 \pm 0.33$ & $-0.52 * * *$ & $-0.45^{* * *}$ \\
\hline \multicolumn{4}{|l|}{ Average thickness of back fat $(1,2,3)$} \\
\hline Meat + bone back ......................... & $-0.08 \pm 0.24$ & $-0.19 * * *$ & $-0.22 * * *$ \\
\hline Meat + bone of ham + loin $\ldots \ldots \ldots \ldots . .$. & $-0.25 \pm 0.25$ & $-0.36 * * *$ & $-0.15^{* *}$ \\
\hline \multicolumn{4}{|l|}{ Main part of carcass: } \\
\hline 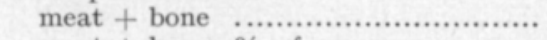 & $-0.24 \pm 0.23$ & $-0.35 * * *$ & $-0.20 * * *$ \\
\hline meat + bone, $\%$ of carcass ............ & $-0.26 \pm 0.25$ & $-0.48 * * *$ & $-0.26 * * *$ \\
\hline 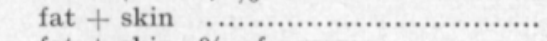 & $0.48 \pm 0.27$ & $0.64 * * *$ & $0.46 * * *$ \\
\hline fat + skin, $\%$ of carcass ............... & $0.39 \pm 0.26$ & $0.62 * * *$ & $0.45^{* * *}$ \\
\hline fat + skin/meat + bone .................. & $0.41 \pm 0.25$ & $0.64 * * *$ & $0.43^{* * *}$ \\
\hline meat + bone (g/day) $\ldots \ldots \ldots \ldots \ldots \ldots \ldots \ldots$ & $-0.60 \pm 0.22$ & $-0.35 * * *$ & $-0.20 * * *$ \\
\hline 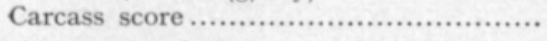 & $-0.46 \pm 0.24$ & $-0.46 * * *$ & $-0.26 * * *$ \\
\hline Average fat thickness $(1,2,3,4)$ & & & \\
\hline 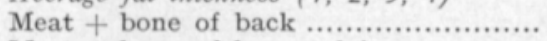 & $-0.10 \pm 0.25$ & $-0.22 * * *$ & $-0.33 * * *$ \\
\hline Meat + bone of ham + loin ...... & $-0.25 \pm 0.26$ & $-0.40 * * *$ & $-0.33 * * *$ \\
\hline Main part of carcass & & & \\
\hline meat + bone........ & $-0.24 \pm 0.24$ & $-0.38 * * *$ & $-0.35 * * *$ \\
\hline meat + bone, $\%$ of carcass ............ & $-0.27 \pm 0.26$ & $-0.52 * * *$ & $-0.42 * * *$ \\
\hline 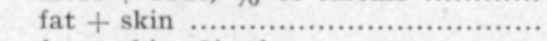 & $0.57 \pm 0.25$ & $0.70^{* * *}$ & $0.58 * * *$ \\
\hline fat + skin, $\%$ of carcass ................ & $0.46 \pm 0.26$ & $0.68^{* * *}$ & $0.59 * * *$ \\
\hline fat + skin/meat + bone $\ldots$ & $0.46 \pm 0.25$ & $0.71 * * *$ & $0.60 * * *$ \\
\hline meat + bone (g/day) $\ldots . .$. & $-0.61 \pm 0.23$ & $-0.39 * * *$ & $-0.36^{* * *}$ \\
\hline 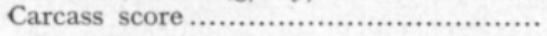 & $-0.47 \pm 0.25$ & $-0.51 * * *$ & $-0.43 * * *$ \\
\hline
\end{tabular}

Correlations calculated from the original data.

* $\mathrm{P}<0.05,{ }^{* *} \mathrm{P}<0.01,{ }^{* * *} \mathrm{P}<0.001$ 
For calculating genetic correlations, the amount of data provided by the progeny of group B $(n=285)$ is rather small. The $r_{g}$ for ultrasonically measured fat thickness $v s$. lean cuts results is in fact very low. The highest $r_{g}$ values were for side and loin fat $v s$. meat + bone of back $(-0.48 \pm 0.39$ and $-0.31 \pm 0.34$ respectively). The $r_{p}$ 's for ultrasonically measured fat $v s$. lean cuts were highly significant in almost every case (Table 32), the withers fat vs. mean + bone $\mathrm{r}_{\mathrm{p}}$ being the lowest. Evidently the thickness of the withers fat is a very good measure of the meatiness of the carcass, but the ultrasonic measurement of this fat is inaccurate.

The genetic and phenotypic correlations between the cross-sectional area of the longissimus muscle and characters reflecting the meatiness or meat yield of the carcass were very high (Table 33). Side length (carcass) correlated well with meat + bone of back, and meat + bone (weight and \%) of the main part of the carcass. No genetic correlation was found between ham measurement and lean cuts results, nor between rate of growth and carcass characteristics. The $r_{p}$ for feed efficiency vs. growth per day $(20-88 \mathrm{~kg})$ of all progeny (Groups $\mathrm{A}+\mathrm{B}$ ) was $-0.35^{* * *}$. It was not possible to determine the genetic correlation between these characteristics because the progeny were group-fed.

Table 33. Genetic $\left(\mathrm{r}_{\mathrm{g}}\right)$ and phenotypic $\left(\mathrm{r}_{\mathrm{p}}\right)$ correlations of cross-sectional area of longissimus muscle and side length of carcass with lean cut data, $\mathrm{n}=427$.

\begin{tabular}{|c|c|c|}
\hline \multirow{2}{*}{ Characteristics } & \multicolumn{2}{|c|}{ Correlations } \\
\hline & $r_{g} \pm$ s.e. & $r_{\mathrm{p}}$ \\
\hline \multicolumn{3}{|l|}{ Longissimus area } \\
\hline Meat + bone of back ............... & $0.79 \pm 0.09$ & $0.62 * * *$ \\
\hline 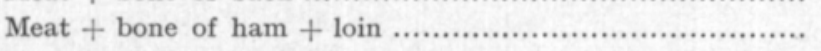 & $1.00 \pm 0.00$ & $0.69 * * *$ \\
\hline \multicolumn{3}{|l|}{ Main part of carcass: } \\
\hline meat + bone $\ldots . . . . .$. & $0.89 \pm 0.05$ & $0.68 * * *$ \\
\hline meat + bone, $\%$ of carcass .................................. & $0.81 \pm 0.09$ & $0.58 * * *$ \\
\hline 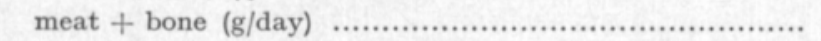 & $1.00 \pm 0.00$ & $0.52 * * *$ \\
\hline 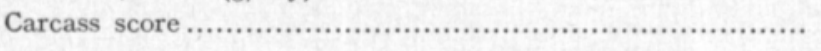 & $0.91 \pm 0.05$ & $0.59 * * *$ \\
\hline \multicolumn{3}{|l|}{ Side length } \\
\hline 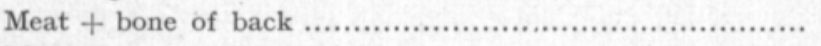 & $0.69 \pm 0.12$ & $0.49 * * *$ \\
\hline 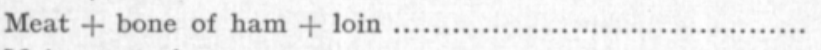 & $0.20 \pm 0.23$ & $0.12^{*}$ \\
\hline \multicolumn{3}{|l|}{ Main part of carcass: } \\
\hline 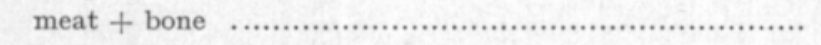 & $0.41 \pm 0.19$ & $0.29 * * *$ \\
\hline meat + bone, $\%$ of carcass . .................................. & $0.53 \pm 0.18$ & $0.25 * * *$ \\
\hline 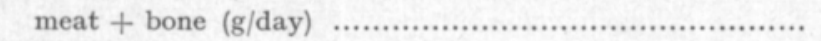 & $0.15 \pm 0.30$ & $0.13^{* *}$ \\
\hline 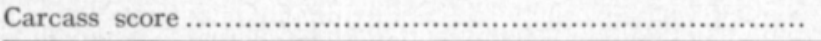 & $0.23 \pm 0.26$ & $0.14 * *$ \\
\hline
\end{tabular}

Correlations calculated from original data

$* \mathrm{P}<0.05,{ }^{* *} \mathrm{P}<0.01,{ }^{* * *} \mathrm{P}<0.001$ 


\section{Investigations on the improvement of station testing of boars}

a. Phenotype and carcass characteristics as indicators of meatiness of carcass

The effectiveness of phenotype evaluation in predicting carcass characteristics was examined by comparing the evaluation results for the Group B progeny with measurements made on the carcass and with the lean cuts results.

The correlations between ultrasonic and carcass fat measurements were as close as those reported elsewhere (Table 34, see Table 1). The closest carcassultrasonic correlation was for side fat (boars $r=0.83^{* * *}$, barrows $0.77^{* * *}$ ); almost as close were the correlations for average side+midback fat $\bar{x}(2,4)$, and for the overall average $\bar{x}(1,2,3,4)$ (Table 34$)$.

The loin fat measurements on the carcass correlated more closely with ultrasonic measurements other than of loin fat. The carcass-ultrasonic correrelation for withers fat $\left(\mathrm{r}=0.69^{* * *}\right.$ and $\left.0.53^{* * *}\right)$ was higher than was to be expected from the correlation between the sires' fat thickness measurements and the progeny withers fat measured ultrasonically or on the carcass (see Tables 28, 29 and 34). If the results of the phenotype evaluation are converted to test points, variation in lean cuts results can be accounted for as follows:

\begin{tabular}{|c|c|c|}
\hline \multirow[b]{2}{*}{ Dependent variables } & \multicolumn{2}{|c|}{ Independent variables } \\
\hline & $\begin{array}{c}\text { Old test } \\
\text { points } \\
R^{2} \%\end{array}$ & $\begin{array}{c}\text { New test } \\
\text { points } \\
R^{2} \%\end{array}$ \\
\hline Meat + bone of back, $g$...... & 9.9 & 17.2 \\
\hline 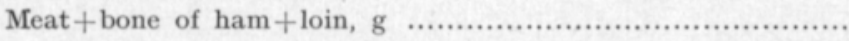 & 9.9 & 21.1 \\
\hline Most valuable parts of the carcass & & \\
\hline meat + bone, $g$...................... & 12.1 & 24.4 \\
\hline,$\quad \%$ of carcass ... & 10.2 & 20.9 \\
\hline fat+skin, $g \quad \ldots \ldots \ldots \ldots \ldots \ldots \ldots$ & 24.8 & 33.8 \\
\hline , $\quad \%$ of carcass ........... & 26.4 & 36.1 \\
\hline 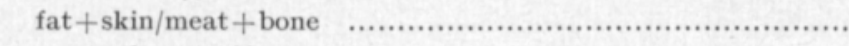 & 25.1 & 39.2 \\
\hline 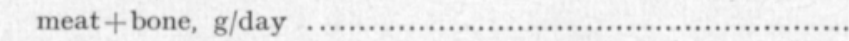 & 24.1 & 26.9 \\
\hline Carcass score .... & 20.7 & 30.4 \\
\hline
\end{tabular}

The new test points accounted better for the variation in lean cuts results than did the old points. The following variables were significant in accounting for the test points of the progeny:

\begin{tabular}{|c|c|c|c|c|c|}
\hline \multirow{3}{*}{ Step } & \multirow{3}{*}{ Independent variable } & \multicolumn{4}{|c|}{ Old test points } \\
\hline & & \multicolumn{2}{|l|}{ Boars } & \multicolumn{2}{|c|}{ Barrows } \\
\hline & & $T$ value & $R^{2} \%$ & $T$ value & $R^{2} \%$ \\
\hline 1 & Average fat thickness $\bar{x}(1,2,3) \ldots \ldots \ldots \ldots \ldots \ldots$ & $-30.32 * * *$ & 76.2 & $-63.31 * * *$ & 84.3 \\
\hline \multirow[t]{3}{*}{2} & 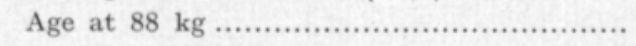 & $-11.85^{* * *}$ & 11.6 & $-20.07 * * *$ & 8.5 \\
\hline & Total .......... & & 89.4 & & 96.7 \\
\hline & & \multicolumn{3}{|c|}{ New test points } & \\
\hline 1 & Average fat thickness $\bar{x}(2,4,5) \ldots \ldots \ldots \ldots \ldots . . . .$. & $-120.56^{* * *}$ & 91.7 & $-58 \cdot 42^{* * *}$ & 88.1 \\
\hline 2 & 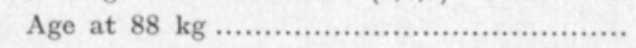 & $-25.85 * * *$ & 4.2 & $-10.61^{* * *}$ & 2.9 \\
\hline 3 & Daily gain .............. & & & $-2.09^{*}$ & 0.1 \\
\hline & Total & & 99.2 & & \\
\hline
\end{tabular}




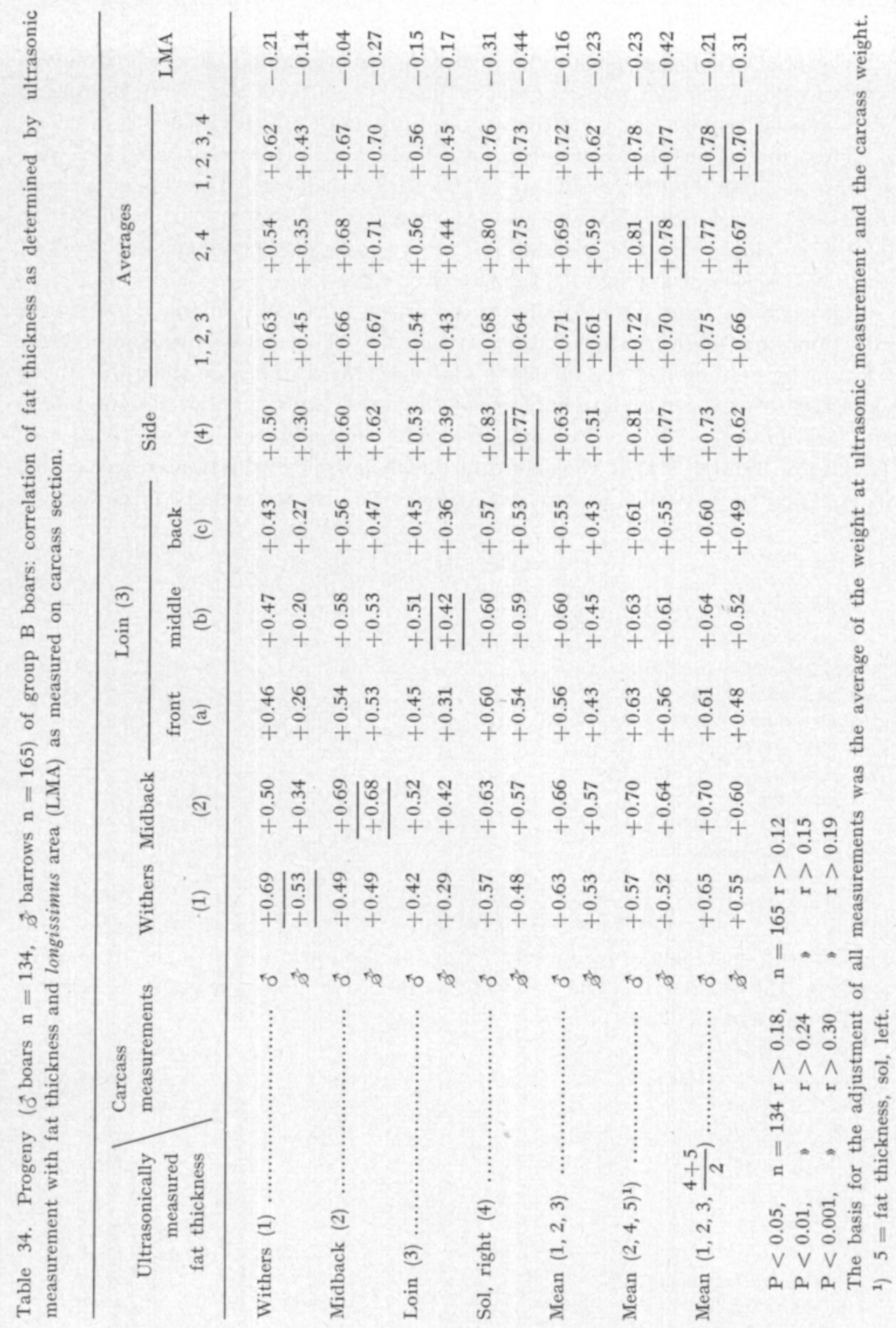


The new test points depended more closely on the thickness of the fat than did the old test points. Thus the importance of the new test points in accounting for variation in carcass value is similar to that of the fat thickness values.

When all the phenotypic characteristics evaluated, i.e. ultrasonic measurements of fat and their averages, daily gain, age at $88 \mathrm{~kg}$ and ham measurement, were used as independent variables in stepwise multiple regression analysis, the

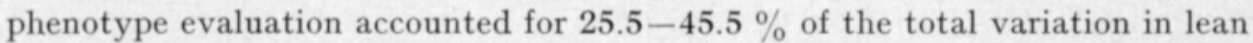
cuts results, $72.1 \%$ in meat + bone produced per day and $51.9 \%$ in carcass score (Table 35).

Either the sol fat or the average of the sol measurements and the fat of the midback proved to be the most important of the independent variables. The other fat thickness values correlated so closely with these fat measurements that they were unable to give any additional information on the variation in carcass quality. Ham measurement and, for most traits, daily growth values gave the most additional information. The age at $88 \mathrm{~kg}$ was an important independent variable in explaining the variations in daily yield of meat + bone and carcass score. This is natural, as this growth craracteristic was used in the calculation of yield and carcass scores (see p. 67).

Of the carcass characteristics the cross-sectional area of the longissimus muscle provided the best estimate of the weight of meat + bone. The second best estimator was fat thickness or length of side. The usefulness of the various fat thickness measurements depended on the carcass characteristic in question. Loin and side fat usually gave additional independent information on the variation in the meat+bone component. The fat thickness averages, on the other hand, accounted significantly for the variation in the fat + skin component. Carcass characteristics and rate of growth together accounted for $47.7-65.6 \%$ of the overall variation in the lean cuts results, for $78.6 \%$ of that in the daily yield of meat+bone, and for $65.0 \%$ of that in the carcass score. The results are some $10-20 \%$ better than those obtained by phenotype evaluation (Table 35).

The daily gain gave negative $T$ values for the yield of meat + bone and fat + skin, except for meat+bone of ham+loin, where the $\mathrm{T}$ value was positive (Table 35). There were apparently two kinds of slow-growing progeny: those low in fat and with good meatiness, and those high in fat and with little meat. A high rate of growth resulted in an increase in the carcass score. Thus daily gain has, independently of the value of the carcass, been selected for.

Using data for the Group B progeny, it was checked if the live animal measurements used in predicting carcass traits were confounded with breed differences; no systematic differences were found. The Landrace minus Yorkshire figure for the ham measurement was $+1.4 \mathrm{~cm}^{*}$, but the meat + bone of ham $-25 \mathrm{~g}^{\mathrm{NS}}$ and the fat + skin amount $+93 \mathrm{~g}^{* * *}$. Yet the ham measurement correlated positively with the meat + bone and negatively with the fat + skin components (Table 35). Side and loin fat were thicker in the Yorkshire progeny than in the Landrace progeny when measured ultrasonically, but in carcass evaluation, where loin fat was measured in three locations, the result was the reverse. The differences between the breeds were not significant in respect of total weight of fat+skin or cross-sectional area of the longissimus muscle. 


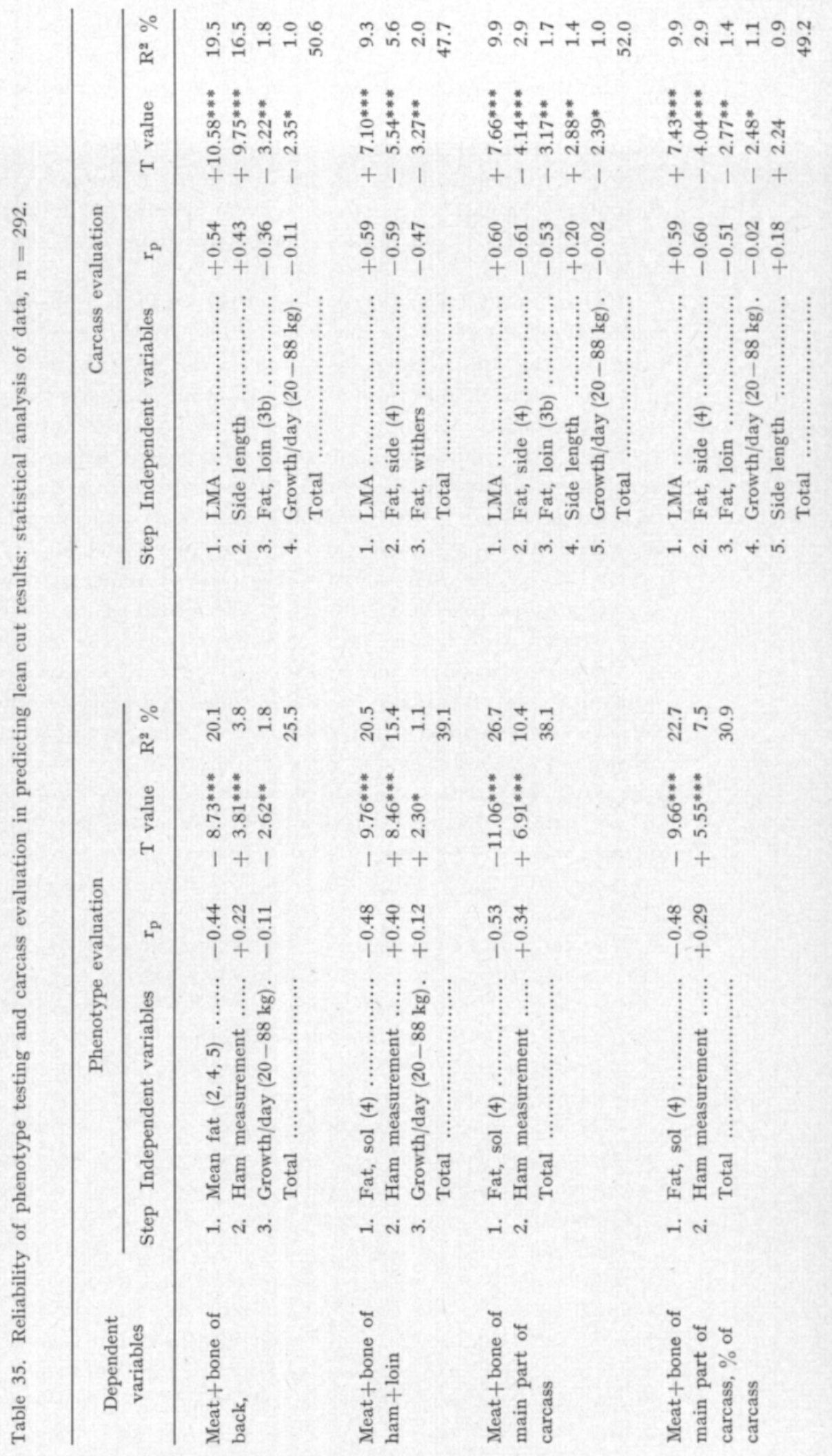


ते

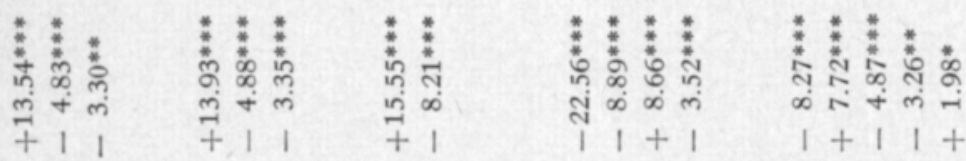

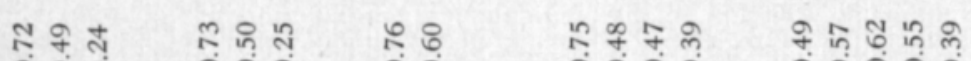
$\begin{array}{llll}+1 & 1 \\ 0 & +1 & 1 & 1\end{array}$

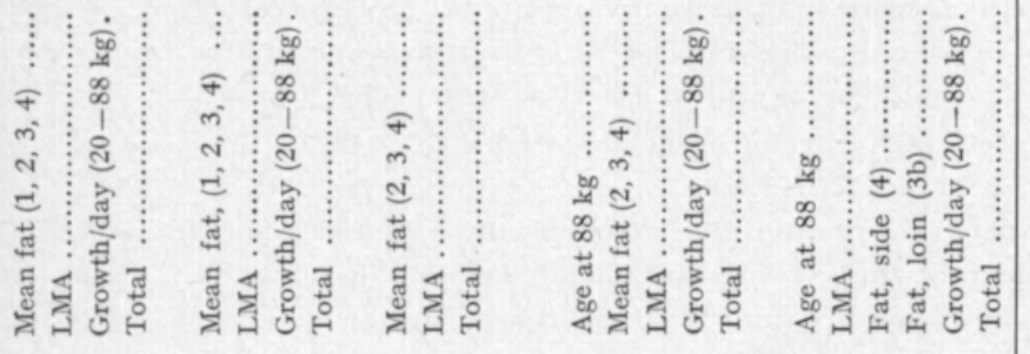
मnm

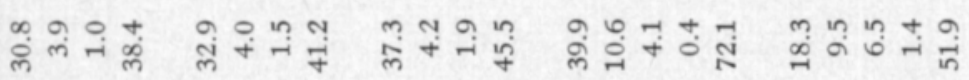

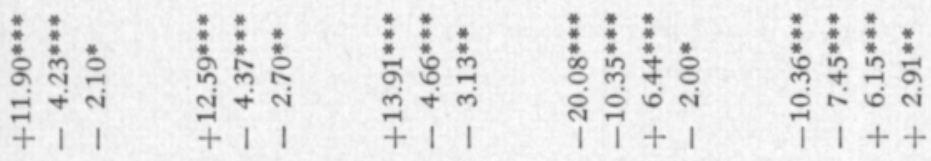

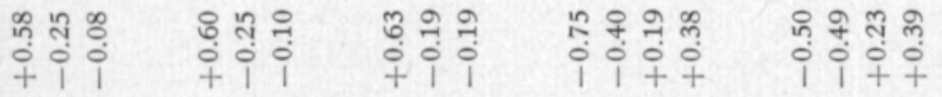

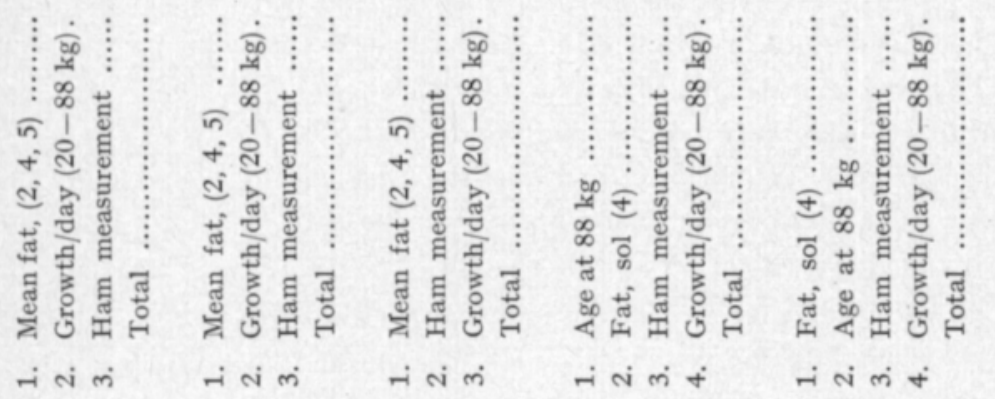

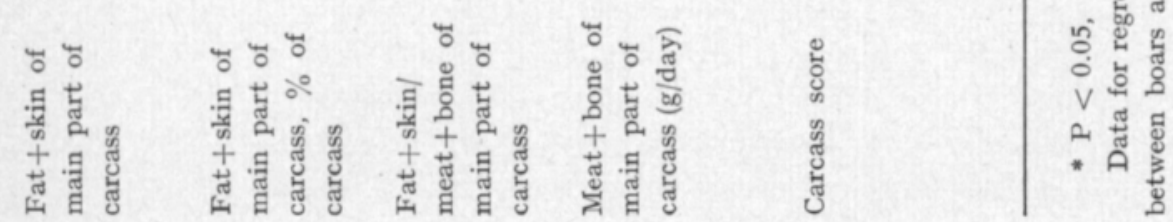


The side length was significantly greater $\left(+2.0 \mathrm{~cm}^{* * *}\right)$ in the Landrace progeny than in the Yorkshire progeny; here it should be recalled that there was no significant difference between the breeds in this respect in the test boars (p. 52).

\section{b. Potential for early selection of boars}

Early testing of the progeny was made in order to investigate the advantages of early culling based on rate of growth. Breeding for rate of growth and obviously also for feed efficiency could be improved in this way. The final evaluation, at the end of the test period, could then be based on carcass characteristics alone.

The early testing was made $\mathbf{8}$ weeks after the commencement of the test period. Ultrasonic measurement of the fat, leg assessment and measurement of the ham were made on the progeny of Group B. The average weight of the progeny at this stage was $58.7 \mathrm{~kg}$ (boars 59.6), and their average age was 122 days (Table 18). For each animal the rate of growth corresponding to this average weight was calculated from its age at $60 \mathrm{~kg}$ and its rate of growth between 20 and $60 \mathrm{~kg}$ liveweight.

The pre-test environment of the piglet had a marked effect on the rate of growth during the period up to the early test (Table 17). However the results of the early test were not influenced by the size and the weight of the litter at 3 weeks. The weight of the pig at three weeks correlated significantly with the weight at the beginning of the test period, but not at the time of the early test. Variations in initial weight and age did not affect the fat thickness of the early test (Table 19).

The weight at ultrasonic measurement was significantly related to the fat thickness at the early test; age at ultrasonic measurement was less closely related (Table 19). Differences in rate of growth and thickness of fat in the early test were highly dependent on differences between the sires (Tables 17 and 19). The influence of sire on fat thickness was more pronounced in the early test than in the regular test (Table 19). The $\mathrm{h}^{2}$-estimates for daily gain of the boars' in the liveweight ranges $20-60$ and $20-70 \mathrm{~kg}$ were reliable and quite high (Table 36 ). The $\mathrm{h}^{2}$-estimate for the daily gain of boar-progeny for the entire test period $(20-88 \mathrm{~kg}$ ) was unexpectedly high (Table 36$)$. The $\mathrm{h}^{2}$-estimates for the rate of growth of the barrows were considerably lower than those for the boars. Variations in growing conditions during the piglet stage had such a great effect upon the age at $60 \mathrm{~kg}$ that $\mathrm{h}^{2}$ was negligible.

The $\mathrm{h}^{2}$-estimates for the fat thickness were also higher for the boars than for the barrows, and actually higher than the $\mathrm{h}^{2}$-estimates for fat thickness of all progeny $(A+B)$ in the regular test (Tables 30 and 36 ). It was surprising, however, that the $\mathrm{h}^{2}$-estimate for midback fat was higher and more reliable in the preliminary test than in the regular test, though the fat thickness in question (average $11.5 \mathrm{~mm}$ ) was the smallest measured in the whole material (Table 18). The $\mathrm{h}^{2}$-estimates for leg points in the early test were also higher 
Table 36. Heritability estimates of growth characteristics at various weight intervals and early-stage phenotype characteristics (measured at a live-weight of about $60 \mathrm{~kg}$ ) determined by half sib correlations for the progeny of Group B boars.

\begin{tabular}{|c|c|c|}
\hline Characteristics & $\begin{array}{c}\text { Boars, } \mathrm{n}=133 \\
\mathrm{~h}^{2} \pm \text { s.e. }\end{array}$ & $\begin{array}{c}\text { Barrows, } \mathrm{n}=165 \\
\mathrm{~h}^{2} \pm \text { s.e. }\end{array}$ \\
\hline Age/60 kg, days ................. & $0.06 \pm 0.12$ & $-0.05 \pm 0.00$ \\
\hline \multirow{4}{*}{ 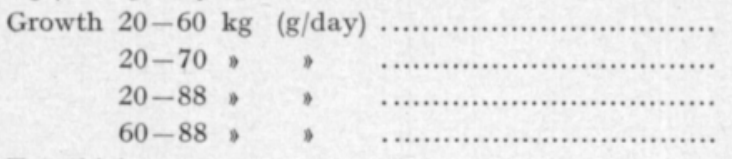 } & $\left.0.67 \pm 0.40^{3}\right)$ & $0.12 \pm 0.16$ \\
\hline & $\left.0.73 \pm 0.42^{3}\right)$ & $0.20 \pm 0.21$ \\
\hline & $\left.0.93 \pm 0.47^{3}\right)$ & $\left.0.34 \pm 0.27^{1}\right)$ \\
\hline & $\left.0.59 \pm 0.38^{2}\right)$ & $0.18 \pm 0.19$ \\
\hline \multirow{7}{*}{ 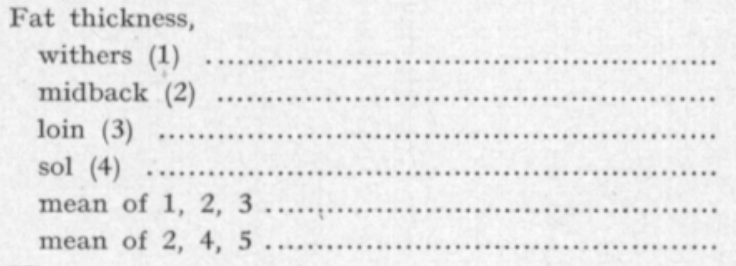 } & & \\
\hline & $0.20 \pm 0.22$ & $0.06 \pm 0.11$ \\
\hline & $\left.0.37 \pm 0.30^{1}\right)$ & $0.18 \pm 0.19$ \\
\hline & $\left.0.31 \pm 0.27^{1}\right)$ & $0.09 \pm 0.13$ \\
\hline & $0.06 \pm 0.12$ & $0.19 \pm 0.19$ \\
\hline & $0.26 \pm 0.25$ & $0.13 \pm 0.16$ \\
\hline & $0.29 \pm 0.26$ & $0.17 \pm 0.18$ \\
\hline \multirow{3}{*}{ 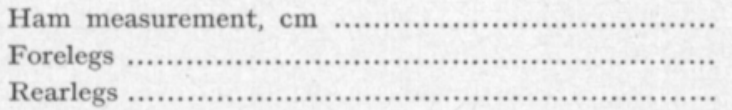 } & $-0.04 \pm 0.00$ & $\left.0.27 \pm 0.23^{1}\right)$ \\
\hline & $\left.0.58 \pm 0.38^{2}\right)$ & $\left.0.44 \pm 0.30^{2}\right)$ \\
\hline & $\left.0.80 \pm 0.45^{3}\right)$ & $\left.0.58 \pm 0.34^{3}\right)$ \\
\hline
\end{tabular}

Uncorrected data were used in the calculations

Levels of significance of between-sire differences:

1) $\left.\left.\mathrm{P}<0.05,{ }^{2}\right) \mathrm{P}<0.01,{ }^{3}\right) \mathrm{P}<0.001$.

and more realible than those obtained in the final test. The heritability for the ham measurement was reliable only for the barrows.

The genetic and phenotypic correlations between the early rate of growth and that during the entire test period were very close (Table 37), due partly of course to autocorrelation. The early growth per day $(20-60 \mathrm{~kg})$, however, correlated very closely with the rate of growth during the later period $(60-$ $88 \mathrm{~kg})$.

With regard to fat thickness, the results of the early test correlated genetically very closely with those of the final test for withers, loin and average backfat but very weakly for midback and sol (Table 38). This order was reversed in the phenotypic correlations, but the differences were smaller. In almost every case the $r_{p}$ was smaller than the $r_{g}$. Naturally, there is autocorrelation between the various fat thicknesses.

Sol fat thickness and ham measurement in the early test were important in predicting a number of lean cuts results, though the latter was significant only in respect of meat + bone (Table 39). It should be noted that sol fat and ham measurement were greatly influenced at this early stage by environmental factors, as theirh ${ }^{2}$ - estimates in the boars were extremely low (Table 36). Also the age at $60 \mathrm{~kg}$, which accounted significantly for variation in daily yield of meat + bone and carcass score, had a low $\mathrm{h}^{2}$-value (Table 36 ).

According to the results described above, early selection of boars at a weight of $60-70 \mathrm{~kg}$, based on their daily growth at a testing station, is reliable, provided 

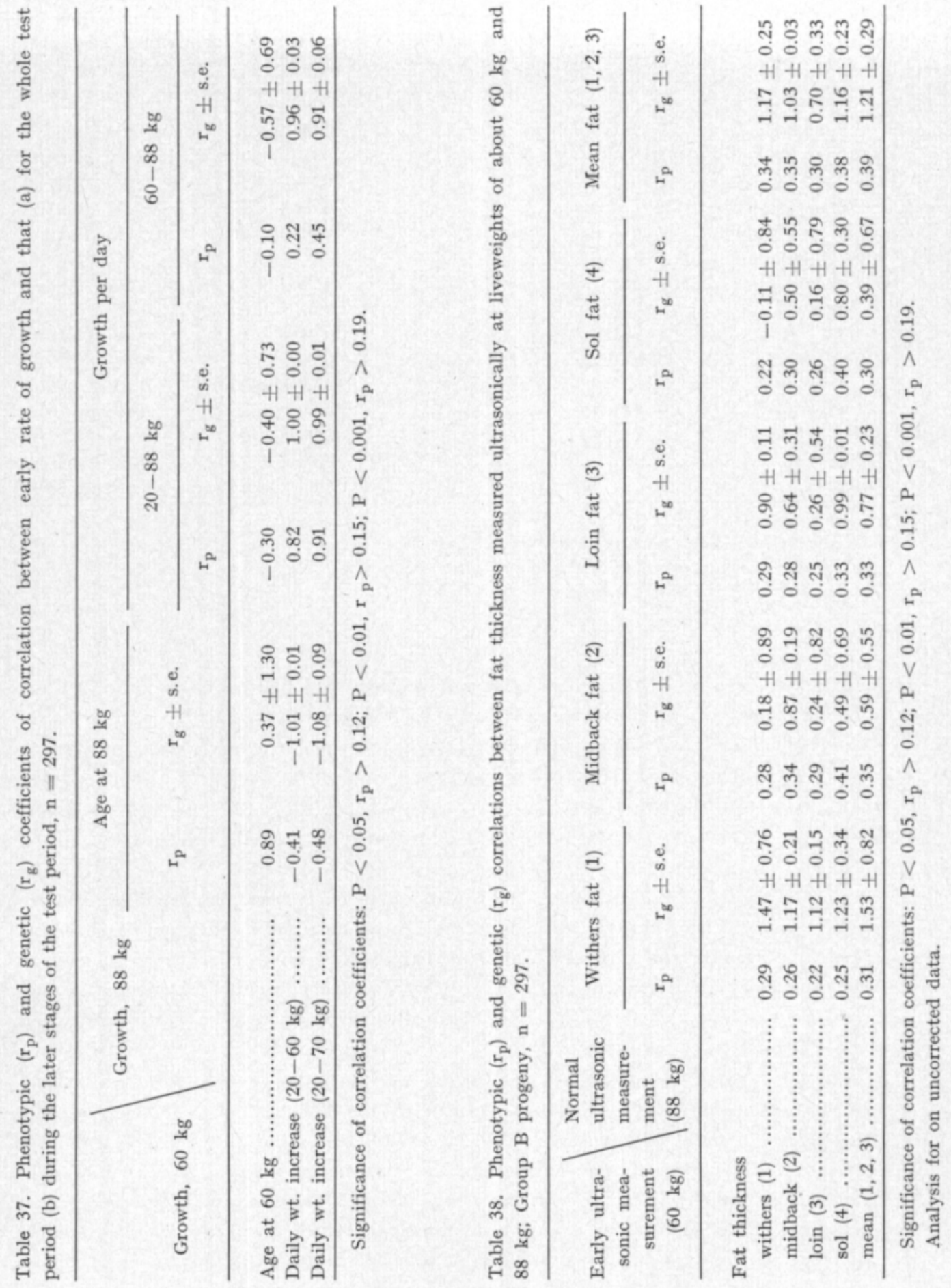
Table 39. Reliability of early-stage ( $60 \mathrm{~kg}$ liveweight) phenotype testing in predicting lean cut results, $\mathrm{n}=287$.

\begin{tabular}{|c|c|c|c|c|c|}
\hline Dependent variables & $\frac{P}{\mathbb{S}}$ & Independent variables & $r_{p}$ & $\mathrm{~T}$ value & $\mathrm{R}^{2} \%$ \\
\hline Meat + bone of back & & $\begin{array}{l}\text { Fat, sol ........................... } \\
\text { Ham measurement } \ldots \ldots \ldots \ldots \ldots \\
\text { Total } \ldots \ldots \ldots \ldots \ldots \ldots \ldots \ldots \ldots \ldots\end{array}$ & $\begin{array}{l}-0.36 \\
+0.18\end{array}$ & $\begin{array}{l}-7.00^{* * *} \\
+4.11^{* * *}\end{array}$ & $\begin{array}{r}14.5 \\
5.0 \\
17.6\end{array}$ \\
\hline $\begin{array}{l}\text { Meat }+ \text { bone of ham }+ \\
\text { loin }\end{array}$ & $\begin{array}{l}1 . \\
2 .\end{array}$ & $\begin{array}{l}\text { Fat, sol } \ldots \ldots \ldots \ldots \ldots \ldots \ldots \\
\text { Ham measurement } \ldots \ldots \ldots \ldots \ldots \\
\text { Total } \ldots \ldots \ldots \ldots \ldots \ldots \ldots \ldots \ldots\end{array}$ & $\begin{array}{l}-0.28 \\
+0.19\end{array}$ & $\begin{array}{l}-5.53^{* * *} \\
+4.02^{* * *}\end{array}$ & $\begin{array}{r}9.5 \\
5.0 \\
13.0\end{array}$ \\
\hline $\begin{array}{l}\text { Meat }+ \text { bone of main } \\
\text { part of carcass }\end{array}$ & & $\begin{array}{l}\text { Fat, sol } \ldots \ldots \ldots \ldots \ldots \ldots \\
\text { Ham measurement } \ldots \ldots \ldots \ldots \ldots \\
\text { Total } \ldots \ldots \ldots \ldots \ldots \ldots \ldots \ldots \ldots\end{array}$ & $\begin{array}{l}-0.40 \\
+0.21\end{array}$ & $\begin{array}{l}-8.05^{* * *} \\
+4.90^{* * *}\end{array}$ & $\begin{array}{r}18.1 \\
6.7 \\
22.3\end{array}$ \\
\hline $\begin{array}{l}\text { Meat }+ \text { bone of main } \\
\text { part, } \% \text { of carcass }\end{array}$ & & $\begin{array}{l}\text { Fat, sol } \ldots \ldots \ldots \ldots \ldots \ldots \\
\text { Ham measurement } \ldots \ldots \ldots \ldots \ldots \\
\text { Total } \ldots \ldots \ldots \ldots \ldots \ldots \ldots \ldots \ldots \ldots\end{array}$ & $\begin{array}{l}-0.35 \\
+0.23\end{array}$ & $\begin{array}{l}-7.18^{* * *} \\
+5.15^{* * *}\end{array}$ & $\begin{array}{r}14.8 \\
7.6 \\
20.1\end{array}$ \\
\hline $\begin{array}{l}\text { Fat }+ \text { skin of main } \\
\text { part of carcass }\end{array}$ & & $\begin{array}{l}\text { Fat, sol } \ldots \ldots \ldots \ldots \ldots \ldots \ldots \ldots \\
\text { Growth/day }(20-60 \mathrm{~kg}) \ldots \ldots \ldots \\
\text { Total } \ldots \ldots \ldots \ldots \ldots \ldots \ldots \ldots \ldots \ldots \ldots \ldots\end{array}$ & $\begin{array}{l}+0.43 \\
-0.20\end{array}$ & $\begin{array}{l}+8.10^{* * *} \\
-3.52^{* * *}\end{array}$ & $\begin{array}{r}18.3 \\
3.4 \\
22.4\end{array}$ \\
\hline $\begin{array}{l}\text { Fat }+ \text { skin of main } \\
\text { part, } \% \text { of carcass }\end{array}$ & & $\begin{array}{l}\text { Fat, sol } \ldots \ldots \ldots \ldots \ldots \ldots \ldots \\
\text { Growth/day }(20-60 \mathrm{~kg}) \ldots \ldots \\
\text { Total } \ldots \ldots \ldots \ldots \ldots \ldots \ldots \ldots \ldots \ldots\end{array}$ & $\begin{array}{l}+0.46 \\
-0.19\end{array}$ & $\begin{array}{l}+8.59^{* * *} \\
-3.36^{* * *}\end{array}$ & $\begin{array}{r}20.1 \\
3.1 \\
23.9\end{array}$ \\
\hline Fat + skin/meat + bone & & $\begin{array}{l}\text { Fat, sol } \ldots \ldots \ldots \ldots \ldots \ldots \\
\text { Ham measurement } \ldots \ldots \ldots \ldots \ldots \\
\text { Total } \ldots \ldots \ldots \ldots \ldots \ldots \ldots \ldots \ldots \ldots\end{array}$ & $\begin{array}{l}+0.48 \\
-0.12\end{array}$ & $\begin{array}{l}+9.67 * * * \\
-3.55^{* * *}\end{array}$ & $\begin{array}{r}24.7 \\
3.3 \\
26.2\end{array}$ \\
\hline $\begin{array}{l}\text { Meat }+ \text { bone of main } \\
\text { part of carcass }(g / \text { day) }\end{array}$ & $\begin{array}{l}1 . \\
2 . \\
3 .\end{array}$ & $\begin{array}{l}\text { Age at } 60 \mathrm{~kg} \ldots \ldots \ldots \ldots \ldots \\
\text { Fat, sol } \ldots \ldots \ldots \ldots \ldots \ldots \ldots \ldots \ldots \\
\text { Ham measurement } \ldots \ldots \ldots \ldots \ldots \\
\text { Total }\end{array}$ & $\begin{array}{l}-0.71 \\
-0.25 \\
+0.12\end{array}$ & $\begin{array}{l}-18.08^{* * *} \\
-6.68^{* * *} \\
+3.66^{* * *}\end{array}$ & $\begin{array}{r}49.4 \\
6.7 \\
2.0 \\
58.0\end{array}$ \\
\hline Carcass score & $\begin{array}{l}1 . \\
2 . \\
3 .\end{array}$ & $\begin{array}{l}\text { Age at } 60 \mathrm{~kg} \ldots \ldots \ldots \ldots \ldots \ldots \ldots \\
\text { Fat, sol } \ldots \ldots \ldots \ldots \ldots \ldots \ldots \ldots \ldots \ldots \\
\text { Ham measurement } \ldots \ldots \ldots \ldots \ldots \\
\text { Total } \ldots \ldots \ldots \ldots \ldots \ldots \ldots \ldots \ldots \ldots \ldots\end{array}$ & $\begin{array}{l}-0.41 \\
-0.34 \\
+0.18\end{array}$ & $\begin{array}{l}-8.22^{* * *} \\
-7.22^{* * *} \\
+4.52^{* * *}\end{array}$ & $\begin{array}{r}16.4 \\
12.6 \\
4.9 \\
32.7\end{array}$ \\
\hline
\end{tabular}

Data for regression analysis was corrected for weight at ultrasonic measurement and weight of carcass: differences between boars and barrows were corrected for in pooling the data

$* \mathrm{P}<0.05, * * \mathrm{P}<0.01, * * * \mathrm{P}<0.001$ 
that the effects of initial weight and age are eliminated. Animals with weak legs could be removed at the same time. Possibly, carcass value could be predicted closely enough by ultrasonic measurements of fat thickness so that supplementary information for use in borderline cases would be got.

\section{c. Leg strength of boars on abundant feeding}

The feeding standards of the progeny of Group B (Table 9, 1969-71) were approximately according to appetite, especially up to a liveweight of $60 \mathrm{~kg}$. They exceeded the feeding standards of the sires by $0.3-0.4 \mathrm{FU} / \mathrm{pig} /$ day (Table 7, 1968-69). For this reason and because of the improved feed quality the growth of the progeny was a great deal faster than that of the sires. The average daily gain of the B sires was $604 \mathrm{~g}$ whereas that of the B progeny boars was $761 \mathrm{~g}$ and that of the progeny barrows $735 \mathrm{~g}$ (Tables 14 and 16).

The dung channel in the stalls was covered with a grid, which caused bruises and swelling in the joints of the legs. None of the progeny had to be slaughtered prior to schedule on account of leg faults. Only five of the pigs ( 1 boar and 4 barrows) out of a total of 298 scored 2 for leg points; i.e. they had to be assisted, for instance at weighing. At the early test about $20 \%$ of the pigs had slight walking impediments ( 3 leg points), the figure being about $38 \%$ at the time of the regular test. Most of the impediments were hoof defects or severe joint swelling. The faults were more severe in the rear legs than in the forelegs. Most of the pigs scored 4 leg points; there were visible defects (slight swelling of rear leg joint, or non-straightening of foreleg) but there was no difficulty in walking. At the time of the regular test $32 \%$ of all recorded defects were swollen joints, $22 \%$ were hoof defects and $16 \%$ were crookedness. About $20 \%$ had faultless legs (5 points) (Table 40 ).

The points for rear legs obtained by the progeny-boars and progeny-barrows in the regular test, grouped according to sire, are given in Table 40 , which is a sire-progeny comparison for leg points. It can be seen that the average leg points of the sires in the three sub-groups were identical, while the legs of the progeny of group III were poorer than those in I and II; the differences, however, were not significant. III contained very few progeny with 5 leg points. In I and II the pigs were distributed very evenly into groups with 3,4 and 5 leg points. The legs of the progeny boars scored higher than those of the barrows, but the difference was not significant.

Boar "Kilperi» had progeny with exceptionally good legs: $70 \%$ of its progeny boars had faultless rear legs (Table 40), and the "Kilperi» progeny differed significantly from three of the other lots of progeny. It was seen earlier (Tables 30 and 36 ) that the $\mathrm{h}^{2}$-estimates for leg points were reliable. The error variance for leg points (regular test) was greater than that in the preliminary test, due possibly to the greater number of leg injuries occuring over the longer period.

Leg defects caused by rapid growth and associated with bone weakness could not be ascertained with statistical reliability, but the correlation between daily gain and points for rear legs was negative for the boars $\left(r_{p}=-0.16\right)$. The corresponding $r_{p}$ for all progeny was almost zero, as were the correlations between meatiness and leg points. The $r_{p}$ 's for the boars' leg points $v s$. the 
various yields of meat found by lean cuts analysis varied from -0.03 to +0.17 ; for example, the $r_{p}$ for points for rear legs vs. meat +bone of the ham was 0.00 .

It can be seen from the above that one-third of the progeny boars were retained for the duration of the testing period despite their impediments to walking (Table 40). One-fifth of the pigs had no leg defects. Hereditary leg weakness and injury were obviously the main factors responsible for the low leg points, rather than the rapid growth or heaviness of the animals.

Table 40. Leg points $\left.{ }^{1}\right)$ of sires and rear-leg points of the progeny in the regular testing (88 $\left.\mathrm{kg}^{\prime}\right)$. Sires, $\mathrm{n}=15$. Progeny: boars $(\hat{\sigma}) \mathrm{n}=133$, barrows $(\hat{\jmath}) \mathrm{n}=165$.

\begin{tabular}{|c|c|c|c|c|c|c|c|c|c|c|c|}
\hline \multirow{3}{*}{ Sires } & \multicolumn{3}{|c|}{ Leg points } & \multicolumn{8}{|c|}{ Frequency distribution of progeny leg points, $\%$} \\
\hline & \multirow{2}{*}{ Sires $\left.^{2}\right)$} & \multicolumn{2}{|c|}{$\begin{array}{l}\text { Averages } \\
\text { for progeny }\end{array}$} & \multicolumn{2}{|c|}{2 points } & \multicolumn{2}{|c|}{3 points } & \multicolumn{2}{|c|}{4 points } & \multicolumn{2}{|c|}{5 points } \\
\hline & & $\hat{\sigma}$ & $\hat{\sigma}$ & $\hat{\sigma}$ & $\hat{\sigma}$ & $\hat{\sigma}$ & $\hat{\not}$ & $\tilde{\sigma}$ & $\hat{\varnothing}$ & $\tilde{\sigma}$ & $\not{8}$ \\
\hline \multicolumn{12}{|l|}{ Sub-group $I}$. \\
\hline 1. Rukki .......... & . 4.0 & 3.7 & 3.9 & - & - & 28.6 & 50.0 & 71.4 & 12.5 & - & 37.5 \\
\hline 2. Riku ............ & . 3.5 & 4.0 & $3.4^{\prime}$ & - & - & 33.3 & 60.0 & 33.3 & 40.0 & 33.3 & - \\
\hline 3. Nakeri ........... & 3.5 & 4.3 & 3.7 & - & - & 27.3 & 45.5 & 18.2 & 36.3 & 54.5 & 18.2 \\
\hline 4. Reka ............ & 4.0 & 4.4 & 4.1 & - & - & 57.1 & 20.0 & 14.3 & 60.0 & 28.6 & 20.0 \\
\hline 5. Hymyri ......... & 4.0 & 4.2 & 4.3 & - & - & 10.0 & 11.1 & 60.0 & 55.6 & 30.0 & 33.3 \\
\hline Average .......... & - 3.8 & 4.1 & 3.9 & & & 29.5 & 37.5 & 38.6 & 41.7 & 31.8 & 20.8 \\
\hline
\end{tabular}

Sub-group II.

\begin{tabular}{|c|c|c|c|c|c|c|c|c|c|c|c|c|}
\hline 6. & Rape ............. & 4.0 & 3.4 & 3.6 & - & 12.5 & 45.5 & 37.5 & 54.5 & 37.5 & - & 12.5 \\
\hline 7. & Kilperi ........... & 4.0 & $4.5^{\mathrm{a}}$ & 4.0 & - & - & 20.0 & 33.3 & 10.0 & 33.3 & 70.0 & 33.3 \\
\hline 8. & Ripa .............. & 4.0 & $3.8^{\mathrm{b}}$ & 3.4 & - & - & 55.6 & 60.0 & 44.4 & 40.0 & - & - \\
\hline 9. & Ranu ............. & 3.0 & 4.0 & 3.8 & - & - & 40.0 & 50.0 & 20.0 & 25.0 & 40.0 & 25.0 \\
\hline \multirow[t]{2}{*}{10.} & Ruuppo ....... & 4.0 & 4.3 & 3.6 & - & 5.9 & 14.3 & 41.2 & 42.8 & 41.2 & 42.9 & 1.7 \\
\hline & Average .......... & 3.8 & 4.0 & 3.7 & - & 3.4 & 36.2 & 44.1 & 34.0 & 35.6 & 29.8 & 16.9 \\
\hline
\end{tabular}

Sub-group $I I I$.

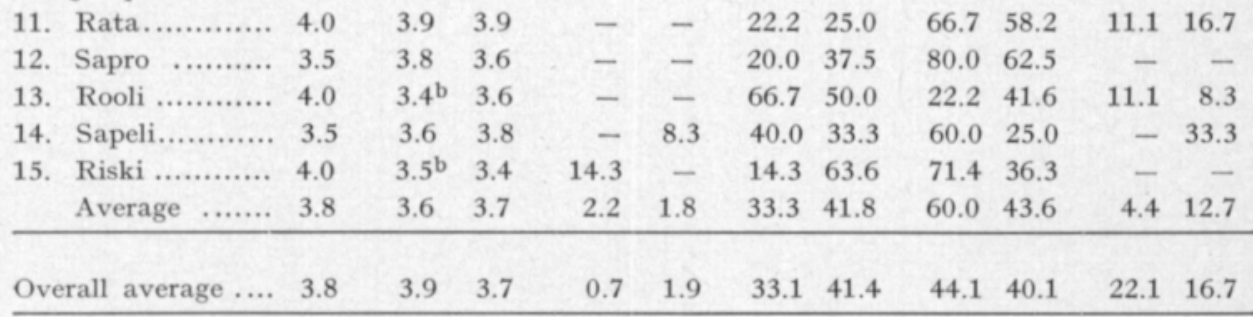

1) Details of scoring:

$1=$ incapable of walking

$2=$ incapable of walking unaided

$3=$ visible defects impeding walking

$4=$ visible defects not impeding walking

$\mathbf{5}=$ no visible defects

${ }^{2}$ ) Forelegs and rearlegs were judged together $\mathrm{a}-\mathrm{b}: \mathrm{P}<0.05$ 


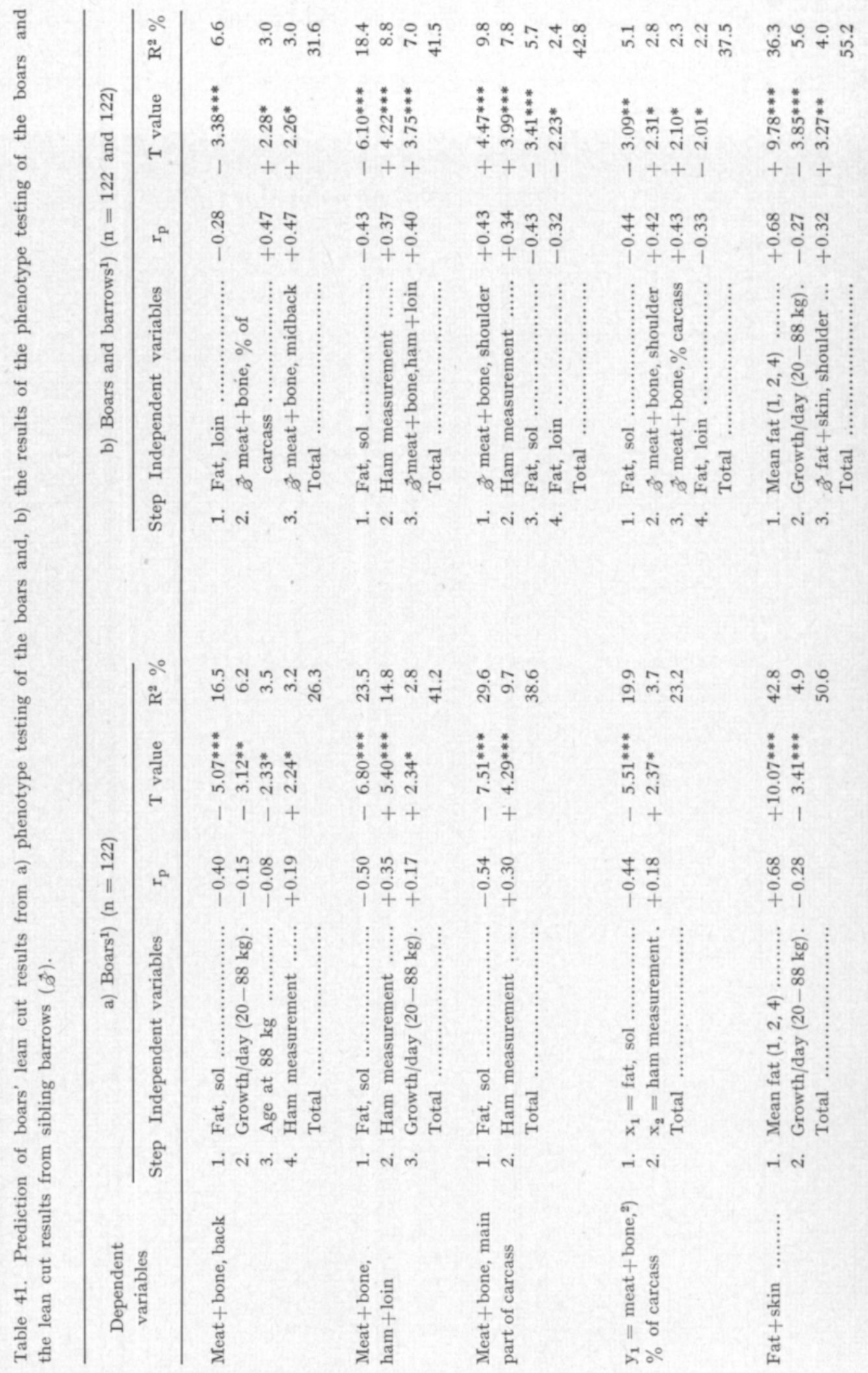


लिं ले लु

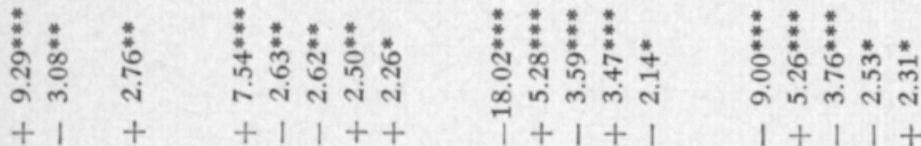

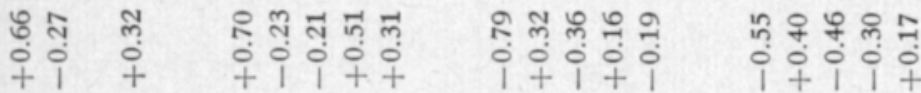

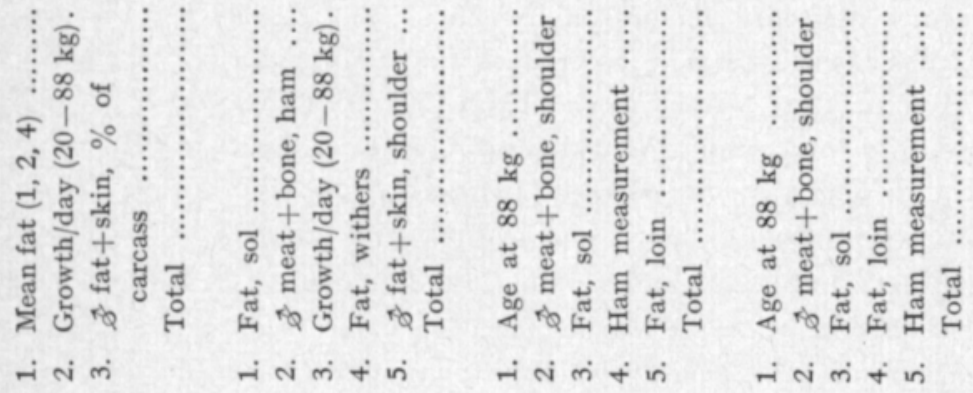

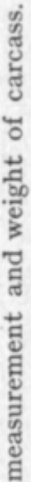

†

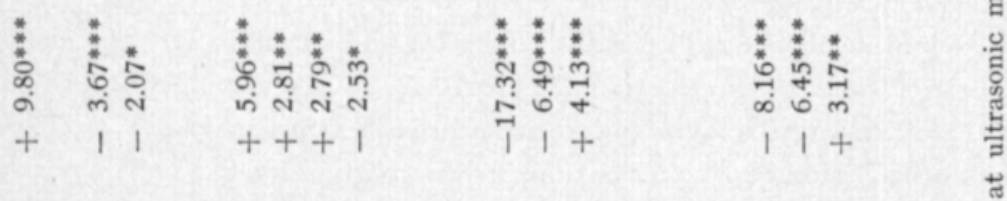

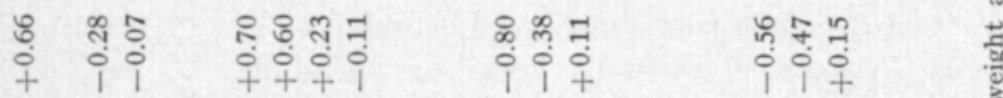

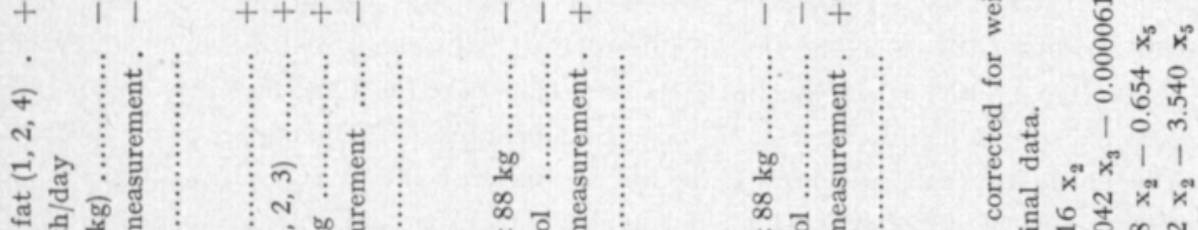

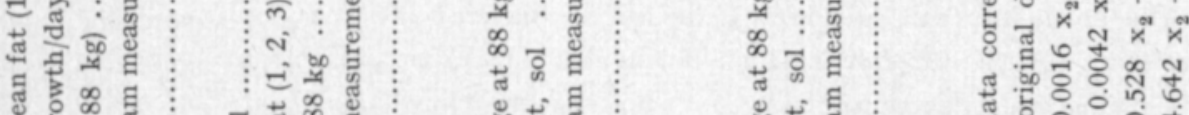

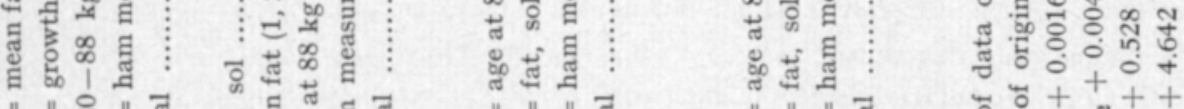

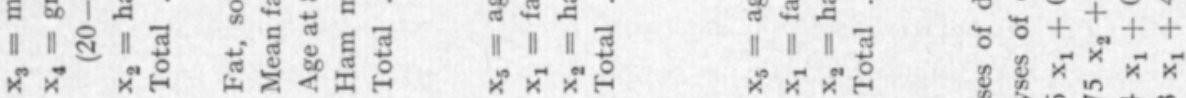

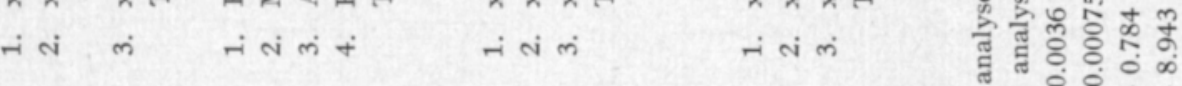

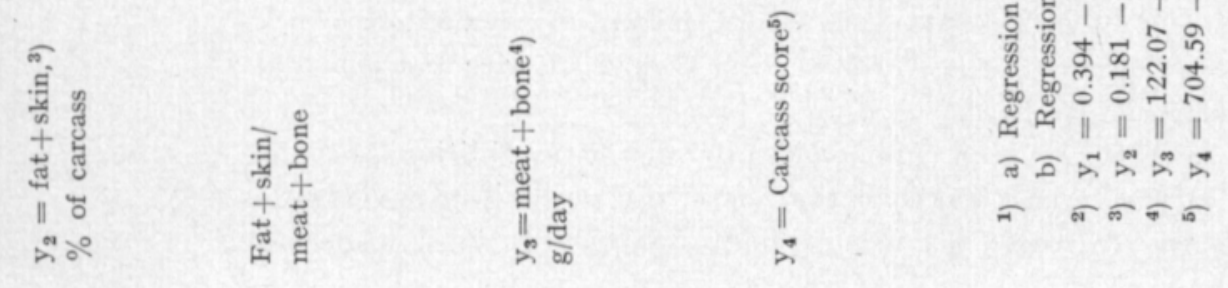


d. Additional information from barrow sibs in assessment of breeding value of boars

Data on the barrow sibs' lean cuts results were analysed for the purpose of seeing if additional information concerning the breeding value of the boars could be obtained. The data used were: boars' phenotype evaluation results, singly and in combination, and barrow sibs' lean cuts results, singly and in combination. These data were used as independent variables in stepwise multiple regression analyses.

The phenotype evaluation results of boars accounted for $23.2-56.4 \%$ of the overall variation in the lean cuts results, $76.6 \%$ of that of the daily yield of meat+bone, and $52.3 \%$ of that of the carcass score (Table 41 a). Those variables which had already been found to provide the best prediction of carcass value, i.e. sol fat, ham measurement and rate of growth (Tables 35 and 39), also gave the best account of the variation in the lean cuts results of the boars. Apart from these, the average withers, midback and sol fat $(1,2,4)$ accounted significantly for the variation in the yield of fat +skin.

The lean cuts results of the barrow sibs accounted significantly for the variation in the carcass characteristics of the boars (Table 41 , a and b), the contribution being $3.2-9.8 \%$. When the lean cuts results of the barrows were combined with those of the phenotype evaluation of the boars as independent variables, the value of the boar variables changed to some extent, loin and withers fat, for example, becoming significant (Table $41 \mathrm{~b}$ ). By combining phenotype evaluation data (boars) and lean cuts data (barrow sibs) it was possible to account for $31.6-58.9 \%$ of the overall variation in the carcass of the boars, $79.3 \%$ for the daily yield of meat + bone, and $61.7 \%$ for the carcass score.

If the lean cuts results for the barrow sibs were taken into consideration in selecting boars for breeding, the compilation of a carcass score from a single lean cuts characteristic would be much simpler than from many such characteristics. Consequently, stepwise multiple regression analyses were carried out including, as independent variables, in addition to the boar's phenotype evaluation results, only the combined lean cuts results from the barrows. Of the barrow variables the most useful were the meat + bone and fat + skin percentages. The weight of meat +bone of the ham and loin provided a better account of the variation in the carcass score than did the other variables (Table 42); however, percentage figures are more suitable for the calculation of carcass score than are weight figures, which are more closely related to the weight of the animal. Relationships containing the variables providing significant accounts of the variation in the meatiness, fat content, daily yield of meat + bone and carcass score of the boar are presented in the form of regression equations. In one series of analyses, the only independent variables were the boars' phenotype evaluation results (Table 41), while in the other these results were combined with the lean cuts results of the barrows (Table 42 ).

Although the barrow sibs' lean cuts results provided little additional account of the variation in the carcass value of the boars, the results are nevertheless valuable because the barrows meat+bone figures proved to be considerably 


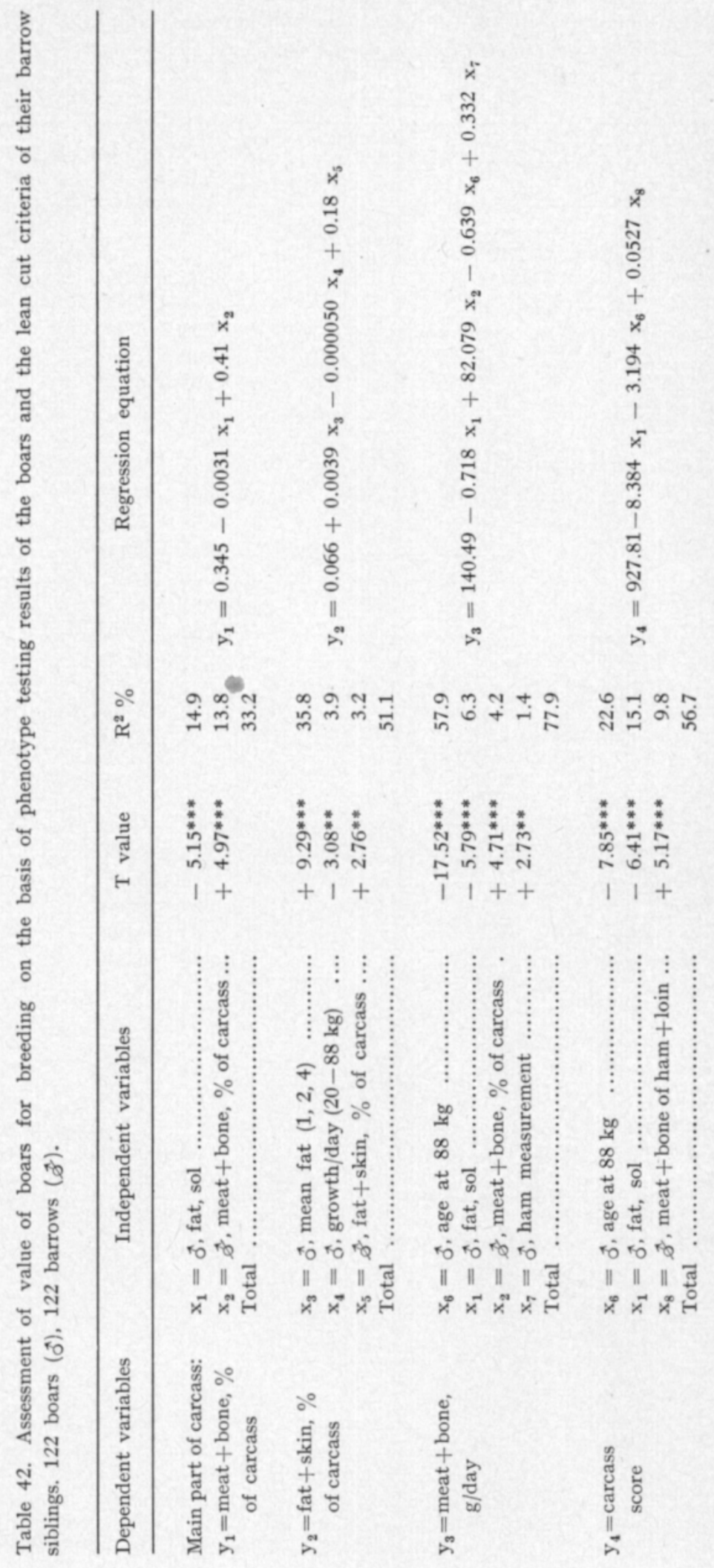


Table 43. Heritability values $\left(\mathrm{h}^{2}\right)$ calculated (using uncorrected data) from the half sib correlations of the carcass characteristics of progeny, measured ultrasonically and after slaughter at about $88 \mathrm{~kg}$ liveweight.

Characteristics

Boars, $\mathrm{n}=122 \quad$ Barrows, $\mathrm{n}=122$

$$
\mathrm{h}^{2} \pm \text { s.e. } \quad \mathrm{h}^{2} \pm \text { s.e. }
$$

Ultrasonically measured fat thickness:

withers (1)

midback (2)

loin (3)

sol (4)

mean 1, 2, 3

mean $2,4,5$

$$
\begin{array}{r}
-0.03 \pm 0.00 \\
0.01 \pm 0.05 \\
-0.05 \pm 0.00 \\
-0.02 \pm 0.00 \\
-0.05 \pm 0.00 \\
-0.02 \pm 0.00
\end{array}
$$

$$
\begin{aligned}
& 0.24 \pm 0.23 \\
& 0.06 \pm 0.12 \\
& \left.0.40 \pm 0.30^{2}\right) \\
& 0.12 \pm 0.16 \\
& 0.25 \pm 0.23 \\
& 0.17 \pm 0.19
\end{aligned}
$$

Fat thickness measured on carcass:

withers (1)

$\left.0.51 \pm 0.35^{2}\right)$

$0.19 \pm 0.19$

midback (2)

$0.58 \pm 0.38^{2}$ )

$0.17 \pm 0.18$

loin (3)

$0.75 \pm 0.43^{3}$ )

$0.49 \pm 0.31^{2}$

side (4)

$0.29 \pm 0.27$

$0.09 \pm 0.13$

mean 1, 2, 3

$0.67 \pm 0.40^{3}$

$0.25 \pm 0.22^{1}$ )

mean $1,2,3,4$

$0.67 \pm 0.40^{3}$ )

$0.15 \pm 0.17$

Lean cuts, half carcass

meat + bone, back

$\begin{array}{ll}\left.0.98 \pm 0.49^{3}\right) & \left.0.63 \pm 0.35^{3}\right) \\ \left.0.53 \pm 0.36^{2}\right) & \left.0.68 \pm 0.36^{3}\right)\end{array}$

\section{Main part}

meat + bone, \%

fat + skin

$\left.0.82 \pm 0.44^{3}\right)$

$\left.0.83 \pm 0.40^{3}\right)$

$0.29 \pm 0.26$

$0.73 \pm 0.38^{3}$

fat + skin, $\%$

$\left.0.47 \pm 0.34^{2}\right)$

$0.07 \pm 0.11$

fat + skin/meat + bone

$0.60 \pm 0.38^{2}$ )

$0.20 \pm 0.20$

meat + bone (g/day)

$0.63 \pm 0.39^{3}$ )

$0.40 \pm 0.29^{2}$

$0.31 \pm 0.28^{1}$ )

$\left.0.30 \pm 0.25^{1}\right)$

carcass score

$0.54 \pm 0.34^{3}$

Other carcass characteristics:

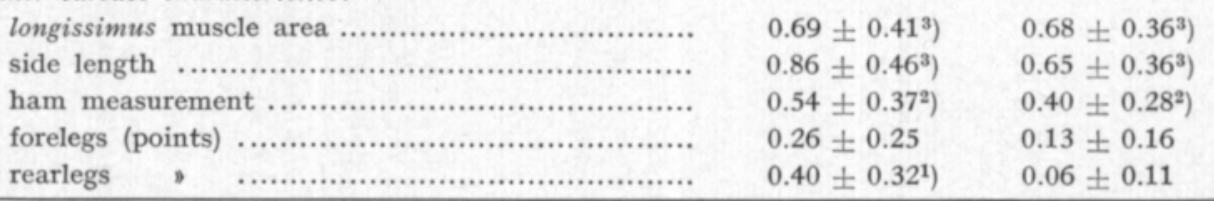

Significance levels of between-sire differences: $\left.\left.{ }^{1}\right) \mathrm{P}<0.05^{2}\right) \mathrm{P}<0.01^{3}$ ) $\mathrm{P}<0.001$. 
more reliable in terms of degree of heritability than did the ultrasonically measured fat thickness measurements of the boars (Table 43). No $\mathrm{h}^{2}$-estimates were obtained for these particular fat figures, though the heritabilities of the corresponding carcass fat thickness, side fat excluded, were very high and reliable (Table 43). For the barrows both the fat thickness measured ultrasonically and on the carcass gave low $\mathrm{h}^{2}$-estimates, of almost the same size. These low $\mathrm{h}^{2}$ 's can be explained, because the fat thickness of barrows markedly affected by the metabolic change resulting from castration, which evidently disrupts the expression of inherited characteristics. This effect can be seen also in the low $\mathrm{h}^{2}$-estimates of the fat + skin components of the barrows (Table 43). The low $\mathrm{h}^{2}$-estimates for the ultrasonically measured boars' fat, however, cannot be the result of anything but the inaccuracy of the measurements. The ultrasonic measurement of fat thickness of the boars was less accurate than that of the barrows for the obvious reason that the relative error is greater with thin fat than with thick. The $\mathrm{h}^{2}$-estimates for ham measurement were relatively high (Table 43).

If the breeding value of the boars had been predicted from their barrow sibs' lean cuts results and rate of growth alone, the following figures would have been obtained:

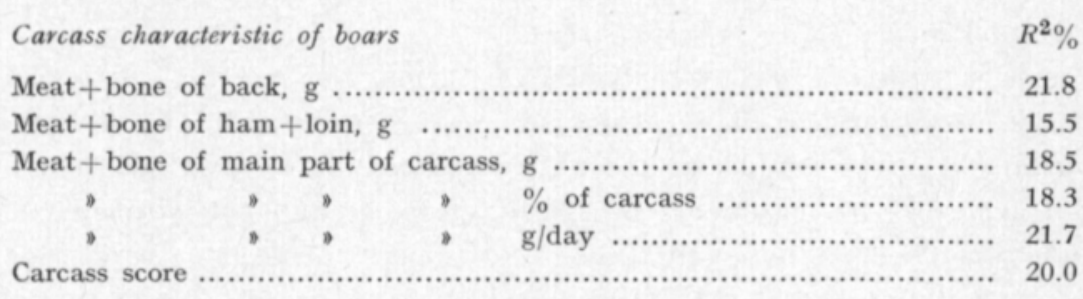

Thus, a phenotype evaluation of boars provides a much more effective account of the variation in their carcass value than a full barrow sib evaluation alone (see. Table 41 a). A combined boar phenotype- and full barrow sib evaluation will provide the best result. 


\section{Discussion}

\section{A. Efficiency of phenotype evaluation of boars}

\section{Influence of animal material on results}

Only a small number of animals can usually be housed at a testing station, so that it is necessary that the preselection, according to the breeding value of the parents, be as strict as possible. Thus the differences between the boar progeny will diminish. It is consequently important to ascertain whether such slight differences can be measured reliably by station testing, or whether the many environmental factors dominate to such an extent that the improvement of boar stock in this way is impossible.

In earlier studies boars were tested on farms, the numbers of boars were large and the differences in fat thickness were considerable (Table 5). There have been very few studies of the type reported here, in which boars were selected according to grading at a testing station, and the efficiency of the selection was checked by evaluation of the boars' progeny, reared also at a testing station. Fewson et al. (1962) and MrNkema et al. (1964) carried out similar investigations, using four progeny-tested boars. The former team graded the boars (two high-grade and two low-grade) on the basis of fat thickness (determined by mleanmeter"), whereas the latter selected by means of an index calculated from feed efficiency, rate of growth, and ultrasonically measured fat thickness and the cross-sectional area of the longissimus muscle. Minkema et al. assessed the one high-grade and 3 low-grade boars (the second high-grade boar had to be replaced by a low-grade) by progeny testing, and compared the results with those of an evaluation of progeny of full sibs. Persson and Lindhé (1972) are using a larger and steadily growing number of pigs, but this work is still in progress.

The study reported here comprises 26 sires and 441 progeny; even numbers of this order are relatively small for heritability studies. In order to increase the differences between the sub-groups it would have been desirable to rear all the 60 test boars at the same time, but owing to the small size of the testing station they had to be reared in two groups $(30,30)$, one after the other. In addition, selection in the later group could not be made simultaneously (see p. 38). It would have been an advantage if all the animals used in the study had been of one breed. However, in order to accelerate the process of evaluating the progeny the use of the two breeds (which to all intents and purposes are the only ones in Finland) was necessary. 
The five best boars, five boars of average ranking, and five poor boars were selected for progeny evaluation from each group of 30 preselected boars. Naturally, the differences between these 3 sub-groups were slight. As an example, for average fat thickness the sub-group I vs. sub-group III difference was only $3.0 \mathrm{~mm}$ in Group A and $5.9 \mathrm{~mm}$ in Group B, the I-II differences being $1.1 \mathrm{~mm}$ and $1.2 \mathrm{~mm}$ respectively (Tables 13 and 14). Consequently, considerable demands are made on the methods of testing if such slight differences in fat values are to be measured reliably by ultrasonic techniques, so that boars with the meatiest progeny may be selected. Ultrasonic measurement has generally been regarded as satisfactory already when it deviates less than $2 \mathrm{~mm}$ from that obtained by measurement of the carcass (see p. 25). Accordingly, the results of this study, in which the sub-group with the poorest carcass quality could be distinguished from the other sub-groups with a reliability of some 95-99.9 per cent, can be regarded as good (Tables $13-14,24-27$, p. 74), and are comparable with the results obtained by Fewson et al. (1962) and Mrnkema et al. (1964) (see. p. 35), as there was no average-grade sub-group in their studies.

In analysing the data, one object was to determine the effect of breed on the results. Breed differences in effect were principally between-boar differences, since selection was based on the number of test points and was quite independent of breed, apart from trying to balance the number of boars of the two breeds (see p. 40). The breed differences found were inconsistent, particularly in carcass characteristics (see p. 85); differences in rate of growth were due mainly to a few exceptionally slow-growing B Group boars (Table 14). Usually the differences in rate of growth between the two Finnish breeds of pig are slight. For example, in a 4-year period immediately preceding this study (1964-67), the daily growth of Landrace pigs on the pig experimental stations was $10 \mathrm{~g}$ less than that of Yorkshires, whereas earlier it had been $10 \mathrm{~g}$ more (LounamaA 1968). In other Finnish tests too, breed differences have been slight or even contradictory (EtTala 1971 a, Maijala and Vainikainen 1962, Uusisalmi $1971 \mathrm{~d}, 1972$ ). This similarity is actually quite understandable, as the breeding programme has been identical for the two breeds.

Differences between the farms from which the progeny of the two breeds were taken can hardly have influenced the results, for the number of farms in question was very high - one of the advantages of the artificial insemination programme. In Group A the Yorkshire progeny were obtained from 26 farms (average 2.8 pigs per farm) and the Landrace progeny from 44 farms (1.8 pigs per farm). The corresponding figures for Group B were 37 farms (2.3 litters per farm) and 53 farms (1.5 litters per farm). Farms from which the progeny of any one boar were taken were situated fairly uniformly all over the collecting area. Exceptions were the three boars lent to farms where they were mated with dams (see p. 44); each of these boars had progeny at 3-6 farms only. Even this ratio, i.e. 3-6 farms per boar, may be regarded as satisfactory for testing purposes (MENNERICH 1967), for as yet AI material is scarce in studies of this kind. Another consequence of the large number of farms was that any close relationship between the dams was quite unlikely (see. p. 44), so that the relationship between the half sibs could be taken as 0.25 . 


\section{Effects of environment}

Environment of the piglet was reflected in the variable weights and ages of the piglets at the commencement of the testing period. The weight of each piglet and the whole litter at the age of three weeks was significantly related to piglet weight at the beginning of the testing and, in turn, initial weight had a significant effect upon the subsequent rate of growth, especially in the range 20 to $60 \mathrm{~kg}$, and to some extent also on fat thickness (Tables 12, 17, 19, 21,23, see p. 33). The effect of initial age on age at 60 and $88 \mathrm{~kg}$ was also significant. In analysing the results, corrections of initial weight were made by means of linear regressions except when hierarchic variance analysis and covariance analysis were performed. Also in Sweden in evaluating growth rate and feed efficiency it was considered necessary to make such corrections (PERSSON \& LINDHÉ 1972). An alternative would be farm rearing of piglets under closely controlled conditions, as has been planned in Sweden in order to minimise variation in initial weight (PERsson and Lindhé 1972).

The effect of weight at ultrasonic measurement on the fat content of the carcass was highly significant when the weight at ultrasonic measurement varied considerably, as was the case with the test boars (Tables 11, 12). A correction in respect of weight was then necessary (see pp. 50, 32). This weight-fat relationship was only slight, however, when the ultrasonic measurement was made once a week, as was the case with the progeny of Group B (Tables 18, 19). A correction for weight was done in all cases except when hierarchic variance analysis and covariance analysis were carried out. Generally, it is quite practicable at boar testing stations to carry out the ultrasonic measurement at a liveweight close enough to the specified one so that no corrections for weight will be necessary. The a g a t ultras onic me a$\mathrm{surement}$ was significant in respect of some fat thickness measurements (Tables 12, 19); corrections for age were not made.

The effect of a mount and composition of f e d (Tables 7-10) on rate of growth and fat thickness was pronounced in the present study, as it has been in many others (see p. 32); there were large differences in rate of growth and fat thickness between the sires and the boar progeny of Group B (sires $604 \mathrm{~g} /$ day, $16.9 \mathrm{~mm}$, boar progeny $761 \mathrm{~g} /$ day, $20.9 \mathrm{~mm}$ ). The feeding of the progeny of Group A was altered in the middle of the testing period, and significant differences in rate of growth and fat content, but not in meatiness, associated with the three feeding regimes (old, new or both standards) were found. Naturally the change in feeding was a disadvantage, and an attempt was made to eliminate its effects by means of pooling (see p. 47). However, the pooling may have diminished the differences between Group A boars to some extent, for although every boar had progeny on each of the feed regimes, the progeny were not evenly distributed in this respect.

The selection of boars at Finnish boar testing stations has from the start been based on a test-points system (Etrala 1971 a). The intention was to reduce fat thickness and increase rate of growth simultaneously, as well as to improve the related characteristics meatiness and feed conversion. In order to ascertain the efficacy of the points system, the boars of Group A were 
graded according to mold s test points, and those of Group B according to mnew" test points. The results showed that the use of test points promoted neither rate of growth nor feed efficiency, for boar selection was based almost entirely upon the thickness of the fat (Table 14, pp. 53, 83), This is consistent with the finding of a previous study (EtTala $1971 \mathrm{~b}$ ) and with that of work in Sweden (PERSSON and Lindhé 1972). The test-points system thus is inappropriate as a criterion in the station testing of boars, for in most cases station testing is used for the specific purpose of quantifying growth rate and feed efficiency, while the test-points system was designed to eliminate differences between farms in field testing (SPANDAL 1972). A specific testing station index for boars has been adopted in Norway and Sweden (Lindhé and PERsson 1972, MOEN 1968).

Of course, ejaculate volume, semen quality and leg strength too are important factors which determine the $\mathrm{value}$ of a stud boar. and these characteristics have consequently been taken into consideration in boar selection in the present study, as they are normally in station testing (see pp. 32, 52). The number of pigs remaining for the progeny evaluation of Group A was smaller than planned, and medium quality reserve boars had to be brought into Group B. In a recent Swedish study on breeding boars for artificial insemination, only $31.2 \%$ of the selected boars could in fact be used in breeding, the remainder having to be rejected because of leg weakness, poor semen or inverted nipples (PERsson and Lindhé 1972).

\section{Heritability estimates of, and phenotypic correlations between, characteristics}

As a test of the reliability of the ultrasonic measurements made on the sires, the $\mathrm{h}^{2}$-estimates obtained from sire-progeny regressions were compared with those from half sib correlations. The two methods gave almost identical $\mathrm{h}^{2}$ estimates $(0.44$ and $0.42 \pm 0.18)$ for average thickness of fat, but this similarity was not always found for individual fat thickness values (Table 31). The $\mathrm{h}^{2}$ value for side fat was the only non significant estimate as determined from carcass measurement and from half sib correlation (Table 31). The $\mathrm{h}^{2}$ estimates were usualy similar to those reported by other investigators (Table 5 , p. 35), although the animal population in question and the environmental conditions have a substantial effect on the magnitude of the heritabilities.

Ultrasonically measured fat thickness of the progeny did not account for the hereditary level of their carcass characteristics as well as ultrasonically measured fat thickness of the sires. Only the $\mathrm{h}^{2}$-estimate for loin fat was statistically reliable when the calculations were made from half sib correlations (Table 30). This is seen also in the correlation between the fat thickness measurements of the sires and those of their progeny. The correlations between ultrasonically measured fat of the sires and the carcass fat measurements of the progeny were much closer than those between sire fat thickness (ultrasonics) and progeny fat thickness (ultrasonics) (Tables 28, 29). The difference was surprisingly large considering the close correlation, found in this and other studies, between progeny fat thicknesses measured on the live animal and on the carcass (Tables 34,1 ). 
The $\mathrm{h}^{2}$-estimate for daily gain $(20-\mathbf{8 8} \mathrm{kg})$ was considerably smaller when determined from the sire-progeny regression $(0.32)$ than when calculated from the half sib correlation $(0.49 \pm 0.19)$ (Table 31$)$, due possibly to the fact that the growth rate of the sires was not expressed fully because of the restricted feeding. The $\mathrm{h}^{2}$ 's determined from the half sib correlations for the boars of Group B are also obvious overestimates (Table 36) that have affected the result. This may partly be due to the group feeding, in which the heavier boars dominated the trough, so that the barrows obtained relatively small amounts of feed. Also, the number of animal in question was small and the range in rates of growth was considerable (Tables 14 and 16).

Environmental conditions during the piglet period had such a great effect on the age at $88 \mathrm{~kg}$ that the $\mathrm{h}^{2}$-estimate was zero (Tables 30 and 31 ). This expression of rate of growth should actually be dropped as far as station testing is concerned. Because the animals were group fed the $\mathrm{h}^{2}$-estimates for the feed efficiency were calculated only from the sire-progeny regressions; the values obtained, 0.25 for Group B and 0.18 for Group A + Group B (Tables 30 and 31), can be regarded as satisfactory.

Correlations between sires and progeny for daily gain and feed efficiency were statistically reliable (Tables 28 and 29). Rate of growth and feed efficiency were closely inter-correlated (Table 15, p. 31), so that the improvement of daily gain and feed efficiency by breeding is possible simultaneously. However, correlations between daily gain and meatiness of carcass and fat content were negative, with few exceptions (Table 35). Probably there have been two types of slow-growing pigs, those with high meatiness + thin fat and those with low meatiness + thick fat. These opposing trends of rate of growth and meatiness or fatness of carcass are evident also in results reported elsewhere (see p. 31). Thus the recommendation that in the selection of stud boars these characteristics should be considered separately seems to be well founded. With this in mind, the potential for early selection by means of early phenotype testing of progeny was studied here.

\section{B. Appraisal of means for the improvement of station testing of boars}

\section{Potential for early selection of boars}

The $\mathrm{h}^{2}$-estimate, calculated from the half sib correlations of the boar progeny, for the early daily gain $(20-60 \mathrm{~kg})$ was $0.67 \pm 0.40$ (Table 36$)$. The early daily gain correlated very closely with the daily gain during the whole test period $(20-88 \mathrm{~kg})$ and with that during the last part of the period $(60-88$ kg) (Table 37); Admittedly, autocorrelation may have been considerable in the former. The genetic correlation between the daily gain in the latter, that is $20-60$ vs. $60-88$, was $\mathrm{r}_{\mathrm{g}}=0.96 \pm 0.03$, and the phenotypic correlation $\mathrm{r}_{\mathrm{p}}=$ $0.22^{* * *}$. It is evident from these values that boars' rate of growth can be determined quite reliably even at a live weight of $60 \mathrm{~kg}$ only. Many other researchers (Buchenauer 1970, Hofmann 1965, Schmid 1970, Scholz 1965, WöHLBIER et al. 1961, ZAGOZEN and FLOCK 1970) have also found that rate of 
growth of pigs (as well as feed efficiency) can be determined quite accurately on the basis of a brief period of growth. The test periods which they used were equivalent to the liveweight range $50-80 \mathrm{~kg}$. In Germany an early selection of boars has been made at $70 \mathrm{~kg}$, using the characteristics rate of growth, feed efficiency and ultrasonically measured fat thickness (BLEND 1970); the boars were on an libitum diet.

In the present study, feed efficiency could not be determined at intermediate stages because the animals were fed in groups. However, growth rate and feed efficiency were closely interrelated, and good utilisation of feed obviously accompanied rapid growth, even during early growth. According to many studies, there are very close (negative) phenotypic and genetic correlations between rate of growth and feed efficiency (see p. 31).

The ham measurement and the ultrasonically measured sol fat found in the early test gave, when combined together, a very reliable prediction of lean cuts results obtained after slaughter at the usual $\mathbf{8 8} \mathrm{kg}$ liveweight (Table 39). The genetic correlation between these early-test results and carcass characteristics, however, was only slight (see p. 89). Extreme values in carcass characteristics could perhaps be predicted by early ultrasonic measurement, so that it might be useful in the selection of borderline cases. Many researchers have found a relatively close correlation between early-measured fat thickness and carcass fatness, but most have concluded that individual differences in carcass characteristics increase with advancing growth (Отто $1967 \mathrm{a}$ and b, Rittler et al. 1964, Schmid 1970, Scholz 1965, SkJervold et al. 1960, VOCKERT 1969). Inspection of the legs should also be included in early testing.

An early selection made on the basis of daily gain, feed efficiency and leg strength of boars would have the advantage, among others, that these economically important characteristics are expressed at their fullest at this stage. Another advantage would be the more effective use of the testing facilities.

\section{Leg strength of boars on various levels of feeding}

On restricted feeding $13 \%$ of the test boars had to be eliminated on account of leg faults, and a further quarter of them had slightly less serious faults, there being some impediment to walking (3 leg points). Among the progeny boars reared on the higher level of feeding, one-third had difficulty in walking but in only one animal was this greatly restricted (Table 40); leg defects associated with bone weakness caused by rapid growth could not be substantiated with statistical reliability. Yet there was a weak negative correlation $\left(r_{p}=-0.16\right)$ between daily gain and rear leg points. It appears thus that the role of feeding in causing leg weakness was a minor one (see p. 32). Carcass meatiness was not correlated at all with leg points (see p. 92), which result contrasts with the negative correlation found by KANGASNIEMI (1971 a) in progeny tests.

Some of the leg faults were inherited. This was already suggested by the fact that 5 of the $\mathbf{8}$ boars rejected because of leg faults came from two litters only, and was confirmed later by the statistically reliable heritability estimates 
calculated from the half sib correlations of progeny (Tables 30 and 36). The $\mathrm{h}^{2}$-estimates for leg points scored at early testing were unexpectedly high (Table 36). One reason may have been over-estimation; another, that the number of leg injuries increased with time, thus decreasing the $\mathrm{h}^{2}$-estimates. In any event, leg faults proved to have a higher heritability in the present study than in that of Sмiтн (1966). From a breeding point of view, it is important that heritable leg defects be revealed by the performance tests.

In the present study leg faults arising through injury were rather numerous. The grid over the waste channel was obviously one cause. It may well be that leg weakness and accidentally cansed leg faults are to some extent associated with clumsiness of movement. Roomy, well-designed stalls provided with bedding should reduce considerably the incidence of leg defects (Schulman 1971).

\section{Predicting carcass quality from results of phenotype testing}

For the phenotype testing of boars to reflect as reliably as possible the breeding value with regard to desirable carcass traits the characteristic should fulfill the following requirements: 1) be accurately measurable, 2) express reliably the meatiness of the carcass, and 3) possess a high heritability and a close genetic correlation to the meatiness of the carcass.

When the measurements of fat thickness made during this study are examined in the light of these requirements, it can be seen that sol fat meets requirements (1) and (2) very well, that loin and withers fat measured on the carcass meet (2) and (3) very well, and that midback fat falls in between these two extremes (Tables $30-32,34,35$ ). As the remaining fat values also meet the requirements to a satisfactory degree, it follows that the fat values supplement one another in this respect. The present study shows that the best estimate of the heritability of carcass characteristics is obtained when the fat thickness, measured ultrasonically, for withers, midback, loin and side are combined. Sol fat need be measured on one side only, since measurement on both sides will not improve the reliability of the estimate. This conclusion is supported by the fact that it was the average of all the sires' fat thickness values, measured ultrasonically, that correlated most closely with their progeny's lean cuts results (Table 29). Ultrasonic measurements at all locations would also ensure an even reduction of fat thickness over the various parts of the carcass as breeding progresses. A number of authors have actually recommended that ultrasonic measurement be made at 3-5 locations (see p. 26).

The ham measurement met the above-mentioned requirements, except that its genetic correlation with carcass meatiness was slight (Tables 30, 35, p. 82). The phenotypic correlation between ham measurement and lean cuts results was surprisingly high (Table 35): considerably higher than that obtained by UUSISALmi (1971 c) when he introduced the use of this characteristic. The use of ham measurement in the prediction of carcass value should be continued, at least for reserach purposes.

The side length and cross-sectional area of the longissimus muscle as measured 
on the carcass of the progeny satisfied all three requirements completely, but were not measured phenotypically. It is unfortunate that progeny side length was not measured on the live animals, for the sires' side length (live animal) is significantly correlated with that of the progeny carcass $\left(\mathrm{r}=0.62^{* * *}\right)$. Many positive correlations between carcass length and meatiness, or at least negative correlations between length and fat content, have been reported (Jonsson 1963, Kline and Gall 1964, Krippl et al. 1965, Müller-haye 1965, Pearson et al. 1956 a, b, 1959, Uusisalmi 1971 a, Varo 1962). Admittedly, others have found no correlation between these characteristics (KLIESH et al. 1960, Pedersen 1968, Rittler et al. 1965).

It can be seen from Table 35 that the cross-sectional area of the longissimus muscle was a very good indicator of the meatiness of the carcass. Its heritability and genetic correlation with meat + bone were also high (Tables 30, 33, 43). This finding agrees with those of several other studies (Tables 4, 6, p. 35). Ultrasonic measurements of the longissimus muscle have, however, been taken rarely, because of the difficulty in making accurate determinations. New ultrasonic equipment nevertheless is expected to bring about an improvement in the situation (Table 2). In Finland results obtained with such equipment are encouraging (VARO 1971). As fat thickness steadily decreases with each generation of stud boars, all other measureable characteristics, in particular the cross-sectional area of the longissimus muscle, become increasingly important.

\section{Additional information about variation in boars' carcass quality from barrow sibs' lean cuts analysis}

Lean cuts results should provide a good indication of the breeding value of the animal, because the yield of meat + bone in particular showed high and reliable $\mathrm{h}^{2}$-estimates (Tables 31 and 43, cf. Uusisalmi $1969 \mathrm{~b}, 1971 \mathrm{~d}$ ).

The barrow sibs' results provided statistically significant but rather low coefficients of determination $\left(\mathrm{R}^{2} \%=3.2-9.8\right)$ (Tables 41,42$)$, in accordance with figures obtained by Schmid (1970). The additional information provided by barrows sibs is valuable not only because the independent variables were highly transmittable but also because the barrow data gave the highest increase in information of variation in the meatiness (meat + bone in \% of carcass) of the boar. This carcass characteristic is an important one, and its variability was accounted for less well than was that of the other carcass characteristics by the phenotypic characteristics of the boars themselves (Table 41 a). Schmid (1970) found that a full sib evaluation supplements a phenotype evaluation of boars, provided that the animals are reared at the same time.

Combining early testing with evaluation of barrow sibs to provide auxiliary data in phenotype testing deserves further study, for it would allow the selection of boars from a large population, and more animals could be tested as boars rather than as barrows. As the rate of growth does not seem to cause any systematic difference in carcass value, animals selected on the basis of rate of growth and feed efficiency could very well be used for sib evaluation. If late-castrated pigs, in the weight range 60 to $88 \mathrm{~kg}$, grow at the same rate as the barrows in 
the present study, i.e. $861 \mathrm{~g} /$ day, this final stage of growth would last five weeks, long enough for the "boar-taint to disappear. KRÜGER et al. (1970) investigated late castration (at about $80 \mathrm{~kg}$ ) and found no undesirable effects provided the animals are kept in clean stalls for one week; the pigs were slaughtered four weeks after castration (at about $100 \mathrm{~kg}$ ) and no "boar-taint" was observed.

For the most reliable results, sib evaluation should be carried out with uncastrated boars. Risks are incurred with castration, and the boar carcass is meatier and has less fat than the barrow (Table 22). Both boars could be selected for breeding, the sib evaluation being based on the phenotype of the brother.

The optimum number of progeny-boars selected from any one litter for phenotype tests is two (Jonsson $1971 \mathrm{~b}$ ). In the present study, boars from the same litter proved to be of equal value in such tests (Tables 13, 14, 25 and 27).

To summarise, the present study showed that the phenotype testing of boars provides a very good measure of the meatiness of their progeny, though the differences in fat thickness were small and the number of boars available for selection at any one time was low. The value of the testing results could obviously be further improved by increasing the number of boars and enhancing the level of feeding. The differences between boars would then be relatively large even in a population of highly selected boars. The reliability of boar carcass evaluation can be improved by increasing the number of locations at which measurements are made, and by testing a second boar from the same litter. Greater importance should be attached to the rate of growth and feed efficiency of boars, by altering the evaluation method, e.g. by employing early testing as described above. As a short generation cycle is another advantage of phenotype testing, its potential for rapid improvement of boar stock is obvious. 


\section{Summary}

The efficiency of phenotype testing highly selected boars was studied. Two groups, each of 30 boars, were tested centrally at stations for growth rate and ultrasonically measured fat thickness. According to test points, made up of a combination of these two traits, the 5 best boars, 5 average boars and the 5 poorest boars where selected for progeny evaluation. In all 26 boars with 441 progeny were tested.

1. The progeny evaluation showed that ultrasonic measurement of the fat thickness of the boars gave a very reliable estimate of the meatiness of their progeny. This conclusion is based on the following observations:

a. Those boars, as a group, giving the poorest carcass quality could be distinguished with statistical reliability $(\mathrm{P}<0.05$ or $\mathrm{P}<0.001)$ from the other groups, even though the differences in fat thickness of the boars were quite small.

b. The average fat thickness by ultrasonic measurements made on the boars correlated very closely with averages obtained from lean cuts analysis of the progeny carcasses.

c. The heritability estimate for fat thickness from sire-progeny regression (average fat thickness determined by ultrasonic measurements on the boars and direct measurement on the carcasses of the progeny) was as good as that from half sib correlation of the progeny $(0.44$ and $0.42 \pm 0.18$ respectively). This similarity was not found for individual fat thickness measurements (e.g. midback fat), however.

2. The correlations between sires and progeny were significant $(\mathrm{P}<0.05)$ for both daily gain (period $20-88 \mathrm{~kg}$ ) and feed efficiency. The heritability estimate for daily gain from sire-progeny regression was slightly lower $(0.32)$ than that found from half sib correlations of the progeny $(0.49 \pm 0.18)$.

3. The importance of rate of growth and feed efficiency has been neglected in selection for breeding as the test points used for the selection of the boars depended almost entirely on fat thickness.

4. The daily gain of the progeny boars could be determined with statistical reliability $(\mathrm{P}<0.001)$ as early as two months after the start of the testing period; their liveweight at this stage was about $60 \mathrm{~kg}$. Thus it is possible to select boars early on the basis of their initial growth (from 20 to 60 or 20 to $70 \mathrm{~kg})$.

5. More than $30 \%$ of both boars and progeny boars suffered from some form of difficulty in walking. $13 \%$ of the boars were eliminated because of leg faults. Leg faults in progeny were mainly inherited or caused through injury. The effect of level of feeding on leg strength appeared to be slight. 
6. The results of the phenotype tests on the boars were affected by the following factors:

a. Changes in feeding had significant effects upon the rate of growth and fat thickness.

b. Variations in initial weight and initial age had a significant effect upon growth rate and feed efficiency. Their greatest effect was on growth rate expressed as age in days at a certain weight.

c. The effect of the weight at ultrasonic measurement on fat thickness was highly significant whenever the variation in the former was considerable. This effect was only slight when the ultrasonic measurement was taken at a liveweight as close as possible to $88 \mathrm{~kg}$ (the animals were weighed weekly). The effect of age at ultrasonic measurement was smaller than that of weight.

8. Among the measurements made on the live progeny and on their carcasses the most useful, in estimating the breeding value of the boar as regards meatiness, were the ultrasonic measurements of fat thickness at withers, midback, loin and side (sol). The ham measurement gave an additional significant account of variation in meatiness. Of the measurements made on the halfcarcass, the cross-sectional area of the longissimus dorsii muscle was the best index of meatiness. Length of side also was a useful measurement.

9. The barrow sibs' lean cuts results gave a highly significant account $\left(\mathrm{R}^{2 \%}=3.2-9.8\right)$ of variations in the quality of the progeny boar carcass. 


\section{REFERENCES}

Andrews, F. N. \& Whaley, R. M. 1955. Measure fat and muscle in live animal and carcass. Rep. Ind. Agric. Exp. Sta. 68: 27-29. (Ref. Horst, P. 1964 b.)

ANon. 1968. Uusi luotausmenetelmä [A new method of ultrasonic measurement]. Sika, 195: $36-37$.

Assadi, J. 1967. Die Messung der Querschnittfläche des M. longissimus dorsi am lebenden Tier unter Verwendung des Ultraschall-Schnittbildgerätes und die Beziehung dieser Messwerte zu einigen Schlachtmerkmalen beim Schwein. Diss., 50 p. Giessen.

Berruecos, J. M., Dillard, E. U. \& Robison, O. W. 1970. Selection for low backfat thickness in swine. J. Anim. Sci. 30: 844-848.

Biedermann, G. 1971. Neue genetische Parameter wichtiger Mast- und Schlachtleistungsmerkmale bei der Deutschen Landrasse. Z. Tierz. Zücht.biol. 88: 291-307.

BlendL, H. M. 1970. Ad-libitum-Fütterung in der Eigenleistungsprüfung beim Schwein. Tierzüchter 22: 576-577.

Brunstad, G. E. \& Fowler, S. H. 1959. Some carcass characteristics of swine in the eighth generation of production under four combinations of full and limited feeding. J. Anim. Sci. 18: $211-220$.

Buchenauer, D. 1970. Untersuchungen über die Aufzuchtleistungen eigenleistungsgeprüfter und ungeprüfter Sauen, sowie die Mastleistung und den Schlachtkörperwert ihrer Nachkommen. Diss., 105 p. Giessen.

Buck, S. F., Harrington, G. \& Johnson, R. F. 1962. The prediction of lean percentage of pigs of bacon weight from carcass measurements. Anim. Prod. 4: 25-36.

Clausen, H. 1959. Måling af rygflaeskets tykkelse på levende grise. Landøkon. Fors.lab. Efterårsmøde 1959: 264-266.

Cole, D. J. A. \& Hardy, B. 1971. Effect of dietary digestible energy and crude protein on performance and carcass of growing pigs. 10th Intern. Congr. Anim. Prod., Theme VII. Mimeogr. 7 p. Versailles.

CoOKe, R., Lodge, G. A. \& Lewis, D. 1972. Influence of energy and protein concentration in the diet on the performance of growing pigs. 1. Response to protein intake on a highenergy diet. Anim. Prod. 14: 35-46.

Cross, H. R., Carpenter, J. W. \& Palmer, A. Z. 1970. Pork carcass muscling: fat, lean and bone ratios. J. Anim. Sci. 30: $866-871$.

Diekmann, A. 1960. Erkennung von Fettansatz und Fleischbildung am lebenden Schwein mit Ultraschall. Diss., 69 p. Göttingen.

Draper, N. R. \& Smith, H. 1966. Applied Regression Analysis p. 407. New York. London. Sydney.

Dumont, B. L. 1957. Nouvelles méthodes pour l'estimation de la qualité des carcasses sur les porcs vivants. FAO/FEZ Tagung über Mastleistungsprüfungen an Schweinen, Kopenhagen. (Ref. Lauprecht, E. 1960).

Enfield, F. D. \& Whatley, J. A., Jr. 1961. Heritability of carcass lenght carcass backfat thickness and loin lean area in swine. J. Anim. Sci. 20: 631-634.

ENGLisch, H-G. 1969. Die Beeinflussung der mittels Ultraschall-Echolot-Messungen festgestellten Schlachtleistungsmerkmale durch Masse und tägliche Zunahme der getesteten Zuchttiere. Arch. Tierzucht 12: 413-425.

Etral. A, E. 1971 a. The performance testing of boars. I. Performance testing on Finnish experimental stations and genetic and environmental influences on test results. J. Scient. Agric. Soc. Finl. 43: 53-62.

-_ 1971 b. II. Phenotypic and genetic correlations. J. Scient. Agric. Soc. Finl. 43: 103-110.

FEnder, M. 1962. Untersuchungen über die Zuverlässigkeit der Abschätzung des Fleisch- und Fettanteiles bei Schweinen aufgrund von Ausschlachtungsbefunden. Z. Tierz. Zücht. biol. 77: 273-284. 
Fewson, D., Fender, M. \& KIRSCH, W. 1962. Prüfungsanstalten als Hilfsmittel für die Selektion in der Schweinezucht. 2. Selektionsversuch zur Prüfung der Effektivität der Eigenleistungsprüfung von Ebern. Z. Tierz. Zücht.biol. 77: 265-272.

FLOCK, D. K. 1970. Genetic parameters of German Landrace pigs estimated from different relationships. J. Anim. Sci. 30: 839-843.

- - Schutzbar, W. von \& Lauprecht, E. 1970. Beziehungen zwischen der Eigenleistung von Jungebern und den Prüfungsergebnissen ihrer Vollgeschwister und Nachkommen. Z. Tierz. Zücht.biol. 86: 316-324.

FredeEn, H. T. \& Jonsson, P. 1957. Genic variance and covariance in Danish Landrace swine as evaluated under a system of individual feeding of progeny test groups. Z. Tierz. Zücht.biol. 70: 348-363.

GERLACH, J. 1967. Untersuchungen über die Selektion von Zuchtsauen unter besonderer Berücksichtigung einer Eigenleistungsprüfung im Züchterstall. Diss., 66 p. Hohenheim.

- -1970 . Echolotmessungen als Hilfsmittel für die Zuchtwertschätzung beim Schwein. 4. Mitteilung. Untersuchungen über die Selektion von Zuchtsauen unter besonderer Berücksichtigung einer Eigenleistungsprüfung im Züchterstall. Z. Tierz. Zücht.biol. $86: 325-348$.

Gerwig, C. 1965 a. Die Anwendung des Ultraschallverfahrens für die Beurteilung der Schlachtqualität bei Ebern. Schw. Landw. Mon.hefte 43: 421-423.

- 1965 b. Haltung und Fütterung von Ebern in Eigenleistungsprüfungen Schw. Landw. Mon.hefte. 43: 423-426.

GLODEK, P. 1964. Uber ein unter praktischen Verhältnissen anwendbares Verfahren zur Abschätzung des Fleischbildungsvermögens lebender Schweine mit Ultraschall. Züchtungskunde 36: $356-370$.

- - Hosman, L. \& Haring, F. 1971. Mastleistung und Schlachtkörperwert europäischer Landrasse-Schweine bei unterschiedlicher Fütterungsintensität. 10th Intern. Congr. Anim. Prod., Theme II. Mimeogr. 7 p. Versailles.

Gray, R. C., Tribble, L. F., Day, B. N. \& Lasley, J. F. 1968. Results of five generations of selection for low backfat thickness in swine. J. Anim. Sci. 27: 331-335.

HALD, A. 1952. Statistical theory with engineering applications. 765 p. New York, London.

Hartmann, W. \& Fewson, D. 1967. Zuchtplanung beim Schwein. Züchtungskunde 39:1-8.

HARveY, W. R. 1966. Least-squares analysis of data with unequal subclass numbers. ARS 20-8. Agric. Res. Service, U.S. Dept. of Agric. 157 p.

Hazel, L. N. \& Kline, E. A. 1952. Mechanical measurement of fatness and carcass value on live hogs. J. Anim. Sci. 11: 313-318.

$-\quad \&$ Kline, E. A. 1959. Ultrasonic measurement of fatness in swine. J. Anim. Sci. 18: $815-819$.

Hetzer, H. O. \& Harvey, W. R. 1967. Selection for high and low fatness in swine. J. Anim. Sci. 26: $1244-1251$.

Hofmann, E. 1965. Untersuchungen zur Frage der frühzeitigen Abschätzung der Mastleistung der Schweine auf Grund von Teilleistungen sowie die Beurteilung der erblichen Veranlagung von Vatertieren. Diss., 83 p. Berlin.

Hofmann, F. \& Peter, W. 1964. Die Anwendungsmöglichkeiten der Speckdickenmessung mit Ultraschall bei der Selektion in der Fleischschweinezucht. Arch. Tierzucht 7: 255-287.

- - Peter, W. \& Boettcher, H. 1965. Eigenleistungsprüfung mit Ultraschall bei Jungsauen. Arch. Tierzucht $8: 331-336$.

Holland, L. A. \& Hazel, L. N. 1958. Relationship of live measurements and carcass characteristics of swine. J. Anim. Sci. 17: 825-833.

Horst, P. 1964 a. Entwicklung eines Verfahrens zur Durchführung von Ultraschallmessungen beim lebenden Schwein. Z. Tierz. Zücht.biol. 80: 341-364.

- 1964 b. Kritische Bewertung der Methoden zur Bestimmung des Schlachtkörperwertes beim lebenden Schwein II. Teil. Z. Tierz. Zücht.biol. 80: 365-401.

- - 1969. Untersuchungen über die züchterische Bedeutung des Ultraschall-Schnittbildverfahrens bei der Eigenleistungs-Prüfung von Jungebern. Z. Tierz. Zücht.biol. 86: 58-88.

- - 1971. Erste Untersuchungsergebnisse über den Einsatz des „Vidoson»-Schnittbildgerätes beim Schwein. Züchtungskunde 43: 208-218. 
Jensen, P., Craig, H. B. \& Robison, O. W. 1967. Phenotypic and genetic associations among carcass traits of swine. J. Anim. Sci. 26: 1252-1260.

Johansson, I. \& KorKman, N. 1950. A study of the variation in production traits of bacon pigs. Acta Agric. Scand. 1: 62-96.

Jonsson, P. 1959. Investigations on group feeding versus individual feeding and the interaction between genotype and environment in pigs. Acta Agric. Scand. 9: 204-228.

- - 1963. Danish pig progeny testing results. Z. Tierz. Zücht.biol. 78: 205-252.

- 1971 a. Population parameter estimates of the Danish Landrace pig. Acta Agric. Scand. 21: $11-16$.

- 1971 b. Model computation on future expectation of genetic gain. Genetic covariation betveen the two sexes in Danish pig progeny testing. Acta Agric. Scand. 21: 17-25.

KaLM, E. 1972. Kriterien zeitgemässer Leistungsprüfung beim Schwein. Tierzüchter 24: 94 , 96-97.

Kangasniemi, R. 1971 a. Jalkavikojen, lihan laadun ja lihakkuuden välisistä vuorosuhteista [On the inter-relationships between leg defects, meat quality and meatiness]. Sika $1971,5: 25,26,29,32,33$.

— - 1971 b. Tuloksia sikakantakokeissa mitattavista ominaisuuksista, niiden keskinäisistä vuorosuhteista ja periytyvyydestä. [Results of characteristics measurable in progeny tests on pigs, and of their inter-relationships and heritability]. Mimeogr. 8 p. Tikkurila.

Krrsch, W., Fewson, D. \& Fender, M. 1962. Prüfungsanstalten als Hilfsmittel für die Selektion in der Schweinezucht. 1. Modellrechnungen über die Effektivität verschiedener Prüfungsmethoden und Prüfungssysteme. Z. Tierz. Zücht.biol. 76: 388-407.

KLIESCH, J. \& Horst, P. 1961. Weitere Untersuchungen zur Frage der Anwendung der Ultraschallmesstechnik für die Beurteilung der Fett- und Fleischentwicklung am lebenden Schwein. Züchtungskunde 33: 447-461.

_- \& Horst, P. 1962. Untersuchungen zur Methodik der Ultraschallmessungen am lebenden Schwein unter Verwendung eines Schnittbildgerätes. Züchtungskunde 34: 350358.

- - Neuhaus, U., Silber, E. \& Kostzewske, H. 1957. Versuche zur Messung der Speckdicke am lebenden Tier mit Hilfe des Ultraschalls. Z. Tierz. Zücht.biol. 70: 29-32.

- - Silber, E. \& Horst, P. 1960. Weiterer Beitrag zur Frage der Bedeutung der Körperlänge beim Schwein. Züchtungskunde 32: 263-268.

KLINE, E. A. \& Goll, D. E. 1964. Relative value of longissimus dorsi muscle area at eight different locations in pork carcass evaluation. J. Anim. Sci. 22:414-417.

- - \& Hazel, L. N. 1955. Loin area at tenth and last rib as related to leanness of pork carcasses. J. Anim. Sci. 14: 659-663.

KrIPPL, J., PAtz, H. \& Simon, D. 1965. Untersuchungen über die Erblichkeitsverhältnisse wichtiger Leistungseigenschaften beim deutschen veredelten Landschwein. Bayer. Landw. J.buch. 42: 917-940.

KrÜger, L., Dzapo, V. \& Jesswein, H. 1970. Der Einfluss einer Spätkastration auf die Mastund Schlachtleistung bei Schweinen. Z. Tierz. Zücht.biol. 86: 356-371.

LANGHolz, H.-J. 1965. Das züchterische Hilfsmittel der stationären Nachkommenprüfung beim Schwein. I. Systematische Einflüsse auf die Ergebnisse aus der Mastleistungsprüfung für Schweine. Acta Agric. Scand. 15: 115-144.

- - 1966. III. Heritabilitäten und genetische Korrelationen beim norwegischen Landschwein. Acta Agric. Scand. 16: 97-114.

Langlet, J. F., ERnst, E. \& Glaner, H. D. 1968. Die Möglichkeit einer Selektion bei Schweinen mit Hilfe von Echolotmessungen unter den Verhältnissen der Praxis. Z. Tierz. Zücht.biol. 85: 27-35.

LAUPREcht, E. 1960. Bericht über Ergebnisse von Messungen mit dem Ultraschall-Echolot an Schweinen. Züchtungskunde 32: 441-449.

- - Kirsch, W., Rittler, A., Münzer, W. \& Fewson, D. 1965. Untersuchungen über die Abschätzung des Anteiles der fleisch-und fettreichen Teilstücke aufgrund von Echolotmessungen am lebenden Schwein. Z. Tierz. Zücht.biol. 81: 89-99.

- - - Scheper, J. \& Schröder, J. 1957. Messungen der Speckdicke lebender Schweine nach dem Echolotverfahren. Mitt. Deut. Landw. Ges. 72: 881-882. 
Lauprecht, E., Schutzbar, W. von \& Flock, D. 1967. Untersuchungen über die Heritabilität der mit dem Ultraschall-Echolot and Jungebern ermittelten Speck- und Muskeltiefe. Z. Tierz. Zücht.biol. 84: 80-95.

- - Walter, E., SaAthoff, T. 1960. Beitrag zur Messung der Querschnittsfläche des langen Rückenmuskels (musculus longissimus dorsi) und der darüberliegenden Fettschicht von lebenden Schweinen mit dem Ultraschall-Echolot. Züchtungskunde 32: 450-464.

LINDHÉ, B. 1971. Tulesborapport nr. 1. Svinskötsel 61, 1: 14-16.

- - \& Persson, J. 1972. Stationsindex för galtar. SHS., Medd. 54, 25 p.

- - \& Sundgren, P.-E. 1969. Ekolodindex. SHS., Medd. 29, 32 p.

Lodge, G. A., Cundy, M. E., CоoкE, R. \& Lewis, D. 1972. Influence of energy and protein concentration in the diet on the performance of growing pigs. 2. Differing nutrient density at a constant energy: protein ratio. Anim. Prod. 14: 47 -55.

LounamaA, P. 1968. Katsaus Suomen Sianjalostusyhdistyksen toimintaan vuosina 1949-1968. [A survey of the programme of the Finnish Pig Breeding Society, 1949-1968]. Sika 196: $19-45$.

Lush, J. L. 1947. Family merit and individual merit as bases for selection. Part I. Amer. Nat. $81: 241-261$,

Maijala, K \& Vainikainen, V. 1962. Uber die Ursachen der Variation in der Dicke des Rückenspeckes an der Versuchsstation für Schweinezucht. J. Scient. Agric. Soc. Finl. 34: $66-82$.

Melrose, D. R. 1967. Beinschwäche bei Schweinen. Tierzüchter 19: 322.

MenNerich, A. 1967. Untersuchungen zur Methode und Anwendung des Echolotmessverfahrens in der Leistungprüfung beim Schwein. Diss., 96 p. Göttingen.

MrNG-Pr Mr, 1962. Genetic and environmental variation analysis program. Dept. of Genetics \& Dairy Sci., Univ. of Wisconsin, Mimeogr.

Minkema, D., Bekedam, M., Kroeske, D. \& Stegenga, Th. 1964. A selection experiment with pigs: comparison of the effectiveness of individual selection and sib selection. Neth. J. Agric. Sci. 12: 318-329.

MoEn, R. A. 1968. Seleksjonsindeks for ungråner. Husdyrforsøksmøtet Norg. Landbr. Høgsk., 1968: $226-230$.

- - 1972. Erfaringer fra norsk fenotypetest av ungråner. Scand. Agric. Res. Soc. Mimeogr* 10 p. Kävlinge.

Müllek-Haye, B. 1965. Die Anwendung von Ultraschallmessungen zur Abschätzung der grobgeweblichen Zusammensetzung von Schlachthälften beim Schwein. Diss., 88 p. Göttingen.

NEBE, H. 1969. Feno- og beinkvalitet hos griser. Norsk Landbruk. 14-15: 8-9.

Nenonen, E. 1971. Parhaan regressioyhtälön valitsemisesta [On the selection of the best regression equation]. Thesis, 24 p. Helsinki.

- -1972 . Maatalouden tutkimuskeskuksen tilastopakkaus [The statistics package of the Agricultural Research Centre]. Tikkurila.

Oтro, E. 1967 a. Verlauf der Zunahme des Rückenmuskels bei Schweinen im Gewicht von 40 bis $115 \mathrm{~kg}$. Tierzucht 21: 402 .

- 1967 b. Rückenspeckzunahme bei Schweinen im Gewicht von 40 bis 115 kg. Tierzucht 21: 602 .

- $-\&$ Sieg, G. 1963. Ultraschallmessungen an lebenden Schweinen. Arch. Tierzucht 6: $470-480$.

— - \& SIEG, G. 1965. Ultraschallmessung der Rückenspeckstärke und Rückenmuskelfläche bei Jungebern. Tierzucht 19: 26-30.

- - Sieg, G. 1966. Ultraschallmessungen bei weiblichen und männlichen Tieren in Zuchtbetriebe. Tierzucht 20: 589-591.

Partanen, J. 1965. Sikakantakokeiden tulokset vuodelta 1964. Summary: Results of pig progeny testing in the year 1964. Sika, 181: 25-51. 
Pearson, A. M., Bratzler, L. J., Deans, R. J., Price, J. F., Hoffer, J. A., Reineke, E. P. \& LUecke, R. W. 1965 a. The use of specific gravity of certain untrimmed pork cuts as a measure of carcass value. J. Anim. Sci. 15: 86-92.

- - Bratzler, L. J., Hoffer, J. A., Price, J. F., Magee, W. T. \& Deans, R. J. 1956 b. The fat-lean ratio in the rough loin as a tool in evaluation of pork carcasses. J. Anim. Sci. 15: 896-901.

- - Bratzler, L. J. \& Magee, W. T. 1958 a. Some simple cut indices for predicting carcass traits of swine. I. Cut-out and loin lean area. J. Anim. Sci. 17: 20-26.

- - Bratzler, L. J. \& Magee, W. T. 1958 b. II. Supplementary measures of leanness. J. Anim. Sci. 17: 27-33.

- - Deans, R. J. \& Bratzler, L. J. 1959. Some lumbar lean measures as related to swine carcass cut-outs and loin eye area. J. Anim. Sci. 18: 1087-1093.

Pedersen, O. K. 1968. Sikojen teuraslaatu [The carcass quality of pigs]. Sika 196: 5-18.

PERsson, J. 1972. Stationsprövning - framtidsväg vid urval av elitgaltar. Husdjur 1972, 3: 26-27.

_ - \& Lrndhé, B. 1972. Individprövning av galtar på station i Sverige. Scand. Agric. Res. Soc. Mimeogr. 14 p. Kävlinge.

Peter, W. 1962. Untersuchungen über die Anwendung des Ultraschall-Echolotgerätes in der Fleischschweinzüchtung. Arch. Tierzucht 5: 385-390.

Plonka, S., Duniec, H. \& Kostyra, T. 1969. Wykorzystanie przyzyciowych pomiarow grubosci sloniny dla selekcji knurkow hodowlanych. Summary: The use of ultrasonic equipment for measuring the thickness of back fat of live animals in breeding boars selection. Acta Agr. \& Silv. Ser. Zoot. 9: $31-40$.

Price, J. F., Pfost, H. B., Pearson, A. M. \& Hall, C. W. 1958. Some observations on the use of ultrasonic measurements for determining fatness and leanness in live animals. J. Anim. Sci. 17: 1156.

- - Pearson, A. M., Pfost, H. B. \& Deans, R. J. 1960. Application of ultrasonic reflection techniques in evaluating fatness and leannes in pigs. J. Anim. Sci. 19: 381-387.

QuiJandria, B., Jr. \& Robison, O. W. 1971. Body weight and backfat deposition in swine: curves and correction factors. J. Anim. Sci. 33: $911-918$.

Ritrtek, A. 1964. Untersuchungen über Echolotmessungen als Hilfsmittel für die Schätzung des Zuchtwertes junger Eber. Diss., 48 p. Hohenheim.

- -1968 a. Echolotmessungen als Hilfsmittel für die Zuchtwertschätzung beim Schwein. 2. Mitteilung. Weitere Untersuchungen über die genetische Fundierung der Echolotmessungen an Jungebern. Z. Tierz. Zücht.biol. 84:179-187.

- - 1968 b. 3. Mitteilung. Abschätzung des Fleisch- und Fettanteiles auf Grund von Echolotmessungen am lebenden Schwein. Z. Tierz. Zücht.biol. 85: 78-89.

- - Schoen, P., Schelper, E. \& Fewson, D. 1964. Zur Frage der Genauigkeit von EcholotMessungen am lebenden Schwein in verschiedenen Gewichtsabschnitten. Züchtungskunde 36: 159-168.

- - Werkmeister, F., Fender, M. \& Fewson, D. 1965. Untersuchungen über die Beziehungen zwischen Massen an der Schlachthälfte und dem Anteil der fleisch- und fettreichen Teilstücke beim Schwein. Züchtungskunde 37: 216-223.

Robison, O. W. 1962. Growth and backfat deposition curves in swine. J. Anim. Sci. $21: 975$.

- - Cooksey, J. H., Chapman, A. B. \& Self, H. L. 1960. Estimation of carcass merit of swine from live animal measurements. J. Anim. Sci. 19: 1013-1023.

SChEFfe, H. 1961. The analysis of variance. 477 p. New York.

Schierbaum, E. 1961. Untersuchungen über die Beziehungen zwischen Rückenspeckdicke und Gesamtkörperfettgehalt. Diss., 71 p. Hannover.

Sснміd, P. 1970. Ein Beitrag zur Eigen- und Geschwisterleistungsprüfung beim Schwein. Diss., 106 p. Zürich.

Sснмгдт, L. 1964. Untersuchungen über die Eigenleistungsprüfung bei Ebern. Bayer. Landw. J.buch 41: $427-439$.

Schmitten, F. 1967. Untersuchungen zur Schätzung phänotypischer und genetischer Parameter für Merkmale der Mastleistung und des Schlachtkőrperwertes beim Schwein unter be- 
sonderer Berücksichtigung der Fleischbeschaffenheit und ihrer Beziehung zur Schlachtkörperzusammensetzung. Diss., 274 p. Bonn.

SchoEN, P. J. 1962. Untersuchungen über die Eignung des Ultra-Schall-Verfahrens für Messungen am lebenden Schwein zur Abschätzung des Fleisch- und Fettanteils. Diss., 55 p. Hohenheim.

SchоLz, U. 1965. Untersuchungen über die Eignung verschiedener Mast- und Schlachtleistungseigenschaften für die Zuchtwahl bei Schweinen. Diss., 88 p. Giessen.

Schulman, A. 1971. Jalkaheikkous [Leg weakness]. Sika 1971, 4: 25.

Schumm, H.-R., Otto, E., Sieg, G., Frederich, W. \& SchaAf, A. 1966. Beitrag zur Eigenleistungsprüfung bei Schweinen. Arch. Tierzucht 9: 37-51.

Siers, D. G. \& Thomson, G. M. 1972. Heritabilities and genetic correlations of carcass and growth traits in swine. J. Anim. Sci. 35: 311-316.

SKJERvold, H. 1962. Nytten av unggrismålingene i avlsarbeidet. Buskap og Avdrått 14: 177180.

- - INDREBø, T. \& ØDEGÁRD, A. K. 1960. Registrering av ryggspekktykkelsen på levende svin. Meld. Norg. Landbr. Høgsk. 39, 4:1-18.

SKÅrman, S. 1960. Erfarenheter vid användning av ultraljud för mätning av späcktjockleken hos slaktsvin. Sv. Svinavelsför. Tidskr. 3: 38-43.

Sмrтн, C. 1966. A note on the heritability of leg weakness scores in pigs. Anim. Prod. 8: 345348.

Sokal, R. R. \& Rohlf, F. J. 1969. Biometry. p. 253-298. San Francisco.

Standal, N. 1962. A scoring-system for pig selection based on performance testing for backfat thickness and rate of gain. Meld. Norg. Landbr. Høgsk. 41, 3, 9 p.

_ - 1968. Muligheter till å påvirke slaktekvaliteten hos svin ved avlsarbeide, Scand, Agric. Res. Soc. Mimeogr. 9 p. Stockholm.

Steel, R. G. D. \& Torrie, J. H. 1960. Principles and procedures of statistics. 481 p. New York.

Stouffer, J. R., Wallentine, M. V., Wellington, G. H. \& Diekmann, A. 1961. Development and application of ultrasonic methods for measuring fat thickness and rib-eye area in cattle and hogs. J. Anim. Sci. 20: 759-767.

Sundgren, P.-E. 1964. Ultraljudtekniken och den praktiska svinaveln. Akt. Lantbr.högsk. 47: $40-44$.

- - 1965. Ekolodets använding vid urval av suggor och galtar. Akt. Lantbr.högsk. 75: 73-76.

- - 1967. Individprövning av svin för tillväxt och fettansättning. Scand. Agric. Res. Soc. XIII Congr., Mimeogr. 5 p. Copenhagen.

- -1969 . Individpröving av svin med utnyttjande av ultraljudteknik. Mimeogr. 24 p. Ultuna.

_ - 1972. Erfarenheter av individpröving av galtar uppfödda under fältfồrhållanden. Scand. Agric. Res. Soc., Mimeogr. 6. p. Kävlinge.

Uusisalmi, U. 1969 a. Vorläufige Ergebnisse über das Messen der Schlachteigenschaften beim Schwein. J. Scient. Agric. Soc. Finl. 41: 50-59.

- 1969 b. Carcass analysis as an aid in pig breeding. Acta Agr. Scand. 19: 214-220.

- 1971 a. The conventional carcass evaluation and the carcass dissection analysis of pigs. J. Scient. Agric. Soc. Finl. 43: 40-52.

_ $1971 \mathrm{~b}$. Evaluation of carcass quality of live pigs at weights of $60 \mathrm{~kg}$ and $90 \mathrm{~kg}$. J. Scient. Agric. Soc. Finl. 43: 111-127.

-1971 c. Ham quality and its relationship to carcass quality. I. Ultrasonic and other measurements. J. Scient. Agric. Soc. Finl. 43: 129-139.

- $1971 \mathrm{~d}$. Inheritance in ham and its components in finnish Landrase and Yorkshire breeds. Acta Agric. Scand. 21: 73-83.

$\ldots-1972$. Simplified dissection as an aid in carcass evaluation on the Landrace and Yorkshire breeds. J. Scient. Agric. Soc. Finl. 44:1-11.

VAnschoubroek, F., Wilde, R. de \& LAmpo, Ph. 1967. The quantitative effects of feed restriction in fattening pigs on weight gain, efficiency of feed utilization and backfat thickness. Anim. Prod. 9:67-74. 
VARO, M. 1962. Über die Begrenzung der Beurteilungseigenschaften bei der Eberauslese. Ann. Agric. Fenn. 1: 267-283.

- - 1971. Sikojen ultraäänikuvauksen tuloksia [Results of ultrasonography of pigs]. Sika 1971, 22: 5-7.

- - Partanen, J. 1965. Bewertung der Heritabilität von einigen Eigenschaften bei Schweinen. Ann. Agric. Fenn. 4: 46-48.

VocKert, P. 1969. Untersuchungen zur Möglichkeit des frühzeitigen Erkennens von Merkmalen der Schlachtkörperzusammensetzung mit Hilfe des Ultraschallmessverfahrens am lebenden Schwein. Diss., 100 p. Berlin.

WEIss, F.-K. 1967. Merkmale der Fleischbeschaffenheit beim Schwein, ihre Erblichkeit und ihre Beziehungen zu Mastleistung und Schlachtkörperwert. Diss., 98 p. Göttingen.

Weniger, J. H., Glodek, P., Mennerich, A. \& Schmidt, L. 1967. Untersuchungen zur Methode und Anwendung des Echolotverfahrens in der Leistungsprüfung beim Schwein. Bayer. Landw. J.buch 44: 842-874.

WRIGHT, U. K. 1967. Combined performance and progeny testing in Northern Ireland- a progress report. 8th Study Meet. Europ. Assoc. Anim. Prod. Mimeogr. 8. p. Ås.

Wussow, W. \& Grosse, F. 1959. Fettgehalt ganzer Schweine und Mastleistungen, ihre gegenseitige Beeinflussung und ihre Eignung als Berechnungsgrundlage für die physiologische Futterverwertung. Arch. Tierzucht 2: 427-438.

WöHLbier, W., Friesecke, H. \& KirchgessNer, M. 1961. Uber die frühzeitige Beurteilung einiger Masteigenschaften wachsender Schweine. Züchtungskunde 33: 488-492.

Zagozen, F. \& Flock, D. 1970. Genetische Aspekte der Mastleistung beim Schwein in verschiedenen Gewichtsabschnitten. Züchtungskunde 42: 43-52.

- - SCHRÖDER, J. 1970. Leistungsfutteranteil je kg Gewichtszunahme als Hilfsmerkmal zur Schätzung der Schlachtkőrperzusammensetzung bei der Eigenleistungsprüfung beim Schwein. Züchtungskunde 42: 53-66.

ZoBrisky, S. E., BRADY, D. E., LASLEY, J. F. \& WEAvER, L. A. 1959. Significant relationships in pork carcass evaluation. II. Measurements and cuts of fat as criteria for live hog value. J. Anim. Sci. 18: 583-588. 


\title{
SELOSTUS
}

\section{Karjujen koeasematestauksen tuloksellisuudesta}

\author{
Elsi Ettala
}

Ketieläinten jalostustieteen laitos, Helsingin Yliopisto ${ }^{1}$ )

Tutkimuksen tarkoituksena on ollut selvittää, voidaanko voimakkaasti valikoidun karjuaineksen jalostusarvoerot saada karjujen yksilökokeissa luotettavasti esille. Tutkimusmateriaalina on ollut kaksi 30 karjun testausryhmää (A ja B), joista kummastakin on valittu jälkeläisarvosteluun testauspisteiden puolesta 5 parasta, 5 keskinkertaista ja 5 heikointa karjua. Karjujen poistot jalkavikojen ja hedelmällisyyshäiriöiden vuoksi ovat jossain määrin vähentäneet sekä jälkeläisarvosteltujen karjujen lukua että valintaryhmien välisiä eroja. Jälkeläisarvostelu on suoritettu 26 karjulle. Jälkeläisiä on ollut 441.

1. Jälkeläisarvostelu on osoittanut, että karjujen silavaluotaus on antanut varsin luotettavan arvion karjujen lihakkuutta periyttävästä kyvystä. Tämä on ilmennyt seuraavasti:

a. Ruho-ominaisuuksiltaan heikoin valintaryhmä on kyetty erottamaan tilastollisella luotettavuudella $(\mathrm{P}<0.05-\mathrm{P}<0.001)$ muista ryhmistä, vaikka testauskarjujen silavanpaksuuserot ovat olleet varsin vähäisiä (äärimmäisten ryhmien keskimääräiset silavanpaksuudet ovat eronneet toisistaan A-karjuilla $3.0 \mathrm{~mm}$ ja B-karjuilla $5.9 \mathrm{~mm}$ ). Paras ja keskinkertainen valintaryhmä eivät ole eronneet merkitsevästi toisistaan. Näiden silavanpaksuuserot ovat olleet erittäin pienet (keskimäärin A-karjuilla $1.1 \mathrm{~mm}$ ja B-karjuilla $1.2 \mathrm{~mm}$ ).

b. Isien silavaluotaustulosten (säkä, keskiselkä, pakara ja kylki) keskiarvo on korreloitunut erittäin merkitsevästi jälkeläisten keskimääräisiin ruhon paloittelutuloksiin sekä merkitsevästi tai lähes merkitsevästi jälkeläisten teurasruhosta mitattuihin silava-arvoihin. Sen sijaan isien ja jälkeläisten luotaustulosten välillä on ollut hyvin heikko yhteys (B-ryhmä). Yhteyden kiinteys on riippunut siitä luotettavuudesta, millä jälkeläisten ruhot on arvioitu.

c. Isien luotaustulosten ja jälkeläisten teurasruhosta määritettyjen keskimääräisten silavamittojen välisestä isä-jälkeläisregressiosta laskettu silavan paksuuden $\mathrm{h}^{2}$-arvio $(0.44)$ on ollut yhtä hyvä kuin jälkelăisten puolisisarkorrelaatiosta määritetty $(0.42 \pm 0.18)$. Yksityisten silavamittojen kohdalla on kuitenkin ollut vaihteluja.

2. Karjujen kasvunopeuden ja rehunkäyttökyvyn periytymisestä ja vaikutuksesta jalostusvalintaan on todettu seuraavaa:

a. Isien påiväkasvun ja jälkeläisten päiväkasvun sekä kummankin ryhmän rehunkäyttōkyvyn välillä on ollut tilastollisesti luotettava yhteys $(\mathrm{P}<0.05)$. Isä-jälkeläisregressiosta laskettu päiväkasvun $\mathrm{h}^{2}$-arvio on ollut jonkin verran heikompi $(0.32)$ kuin jälkeläisten puolisisarkorrelaatiosta määritetty $(0.49 \pm 0.18)$.

b. Kasvunopeus ja rehunkäyttökyky ovat jääneet jalostusvalinnassa kokonaan huomioon ottamatta. Tämä on johtunut valintaperusteina käytettyjen testauspisteiden luonteesta. Pisteet ovat muodostuneet miltei pelkästäån silavan paksuuden mukaan. Kasvunopeus ja rehunkäyttőkyky ovat vaikuttaneet niihin hyvin vähän. Kyseinen testauspistejärjestelmä ei sen tähden sovellu käytettäväksi koeasematestauksessa.

3. Yksilökokeen tuloksiin ovat merkitsevästi vaikuttaneet seuraavat ulkoiset tekijät:

a. Eläinten ruokintataso ja rehun laatu ovat vaikuttaneet merkitsevästi kasvunopeuteen ja silavan paksuuteen.

1) Nykyinen osoite: Maatalouden tutkimuskeskus, Kotieläinhoidon tutkimuslaitos, Tikkurila. 
b. Alkupainon ja alkuiän vaihtelut ovat vaikuttaneet merkitsevästi kasvunopeuteen ja rehunkäyttökykyyn. Voimakkaimmin ne ovat vaikuttaneet ikäpäivien luvulla tietynpainoisena ilmaistuun kasvunopeuteen.

c. Luotauspainon vaikutus silavan paksuuteen on ollut erittäin merkitsevä silloin, kun painot ovat vaihdelleet huomattavasti. Sen sijaan painon vaikutus on ollut vähäinen, jos luotaus on suoritettu viikkopunnitusten yhteydessä mahdollisimman lähellä $88 \mathrm{~kg}: \mathrm{n}$ elopainoa. Luotausiän vaikutus on ollut pienempi kuin painon.

4. Liikuntahäiriöistä kärsineitä eläimiä on ollut sekä testauskarjuista että jälkeläiskarjuista yli $30 \%$. Testauskarjuista on jalkavikojen vuoksi poistettu $13 \%$. Jälkeläisissä ilmenneet jalkaviat ovat olleet pääasiassa joko perinnöllisiä tai tapaturmaisesti syntyneitä. Ruokinnan vaikutus jalkojen kestävyyteen on vaikuttanut vähäiseltä.

5. Koeasematestauksen kehittämiseksi tehdyissä selvityksissä on todettu:

a. Karjujen päiväkasvu on tilastollisella luotettavuudella $(\mathrm{P}<0.001)$ voitu märíttää jo kahden kuukauden kuluttua kokeen alkamisesta karjujen ollessa n. $60 \mathrm{~kg}$ :n painoisia. Tämä tekee mahdolliseksi karjujen esikarsinnan varhaiskasvun $(20-60 \mathrm{~kg}$ tai $20-70 \mathrm{~kg})$ perusteella. Esikarsinnassa voitaisiin ottaa huomioon myös jalkojen heikkous, koska varhaistestauksessa annettujen jalkapisteiden $\mathrm{h}^{2}$-arviot on todettu tilastollisesti luotettaviksi.

b. Jälkeläiskarjujen mittausten ja ruhon paloittelutulosten perusteella on todettu, että varmin arvio karjun lihakkuudesta on saatu, kun silavaluotaus on suoritettu säältä, keskiselältä, pakaralta ja kyljeltä (sol). Kinkun ympärysmitta on antanut merkitsevän lisäselityksen ruhon lihakkuuden vaihteluista. Teurasruhomittauksista on longissimus dorsii-lihaksen poikkileikkauspinta-ala ollut paras lihakkuusmuuntelun selittäjä. Merkitsevän lisäselityksen on antanut myös kylkipituus.

c. Leikkosisarten ruhon paloittelutulokset ovat antaneet tilastollisesti erittäin merkitsevän lisäselityksen karjun ruhon arvon vaihteluista ( $R^{2} \%: 3.2-9.8 \%$-yksikköä). 